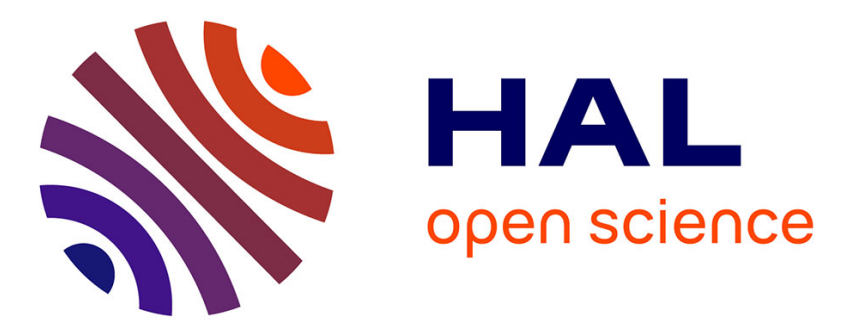

\title{
Volcanic successions in Marquesas eruptive centers: A departure from the Hawaiian model
}

Hervé Guillou, René C. Maury, Gérard Guille, Catherine Chauvel, Philippe

Rossi, Carlos Pallares, Christelle Legendre, Sylvain Blais, Céline C. Liorzou, Sébastien Deroussi

\section{To cite this version:}

Hervé Guillou, René C. Maury, Gérard Guille, Catherine Chauvel, Philippe Rossi, et al.. Volcanic successions in Marquesas eruptive centers: A departure from the Hawaiian model. Journal of Volcanology and Geothermal Research, 2014, 276, pp.173-188. 10.1016/j.jvolgeores.2013.12.003 . insu-00933782

\section{HAL Id: insu-00933782 \\ https://hal-insu.archives-ouvertes.fr/insu-00933782}

Submitted on 25 Feb 2014

HAL is a multi-disciplinary open access archive for the deposit and dissemination of scientific research documents, whether they are published or not. The documents may come from teaching and research institutions in France or abroad, or from public or private research centers.
L'archive ouverte pluridisciplinaire HAL, est destinée au dépôt et à la diffusion de documents scientifiques de niveau recherche, publiés ou non, émanant des établissements d'enseignement et de recherche français ou étrangers, des laboratoires publics ou privés. 


\section{Volcanic successions in Marquesas eruptive centers: A departure} from the Hawaiian model

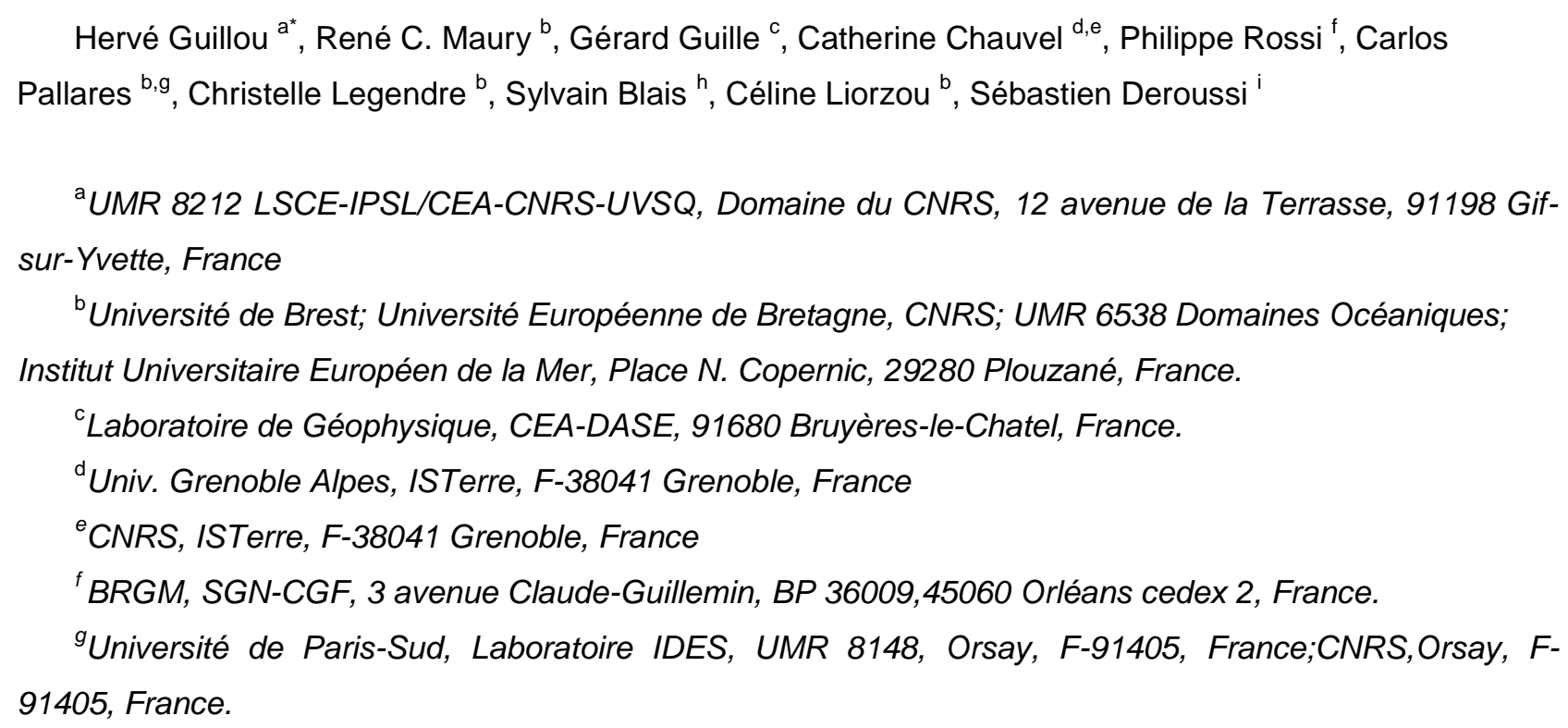

${ }^{a}$ UMR 8212 LSCE-IPSL/CEA-CNRS-UVSQ, Domaine du CNRS, 12 avenue de la Terrasse, 91198 Gifsur-Yvette, France

${ }^{\mathrm{b}}$ Université de Brest; Université Européenne de Bretagne, CNRS; UMR 6538 Domaines Océaniques; Institut Universitaire Européen de la Mer, Place N. Copernic, 29280 Plouzané, France.

${ }^{\circ}$ Laboratoire de Géophysique, CEA-DASE, 91680 Bruyères-le-Chatel, France.

'Univ. Grenoble Alpes, ISTerre, F-38041 Grenoble, France

${ }^{e}$ CNRS, ISTerre, F-38041 Grenoble, France

${ }^{\dagger}$ BRGM, SGN-CGF, 3 avenue Claude-Guillemin, BP 36009,45060 Orléans cedex 2, France.

${ }^{g}$ Université de Paris-Sud, Laboratoire IDES, UMR 8148, Orsay, F-91405, France;CNRS,Orsay, F91405, France.

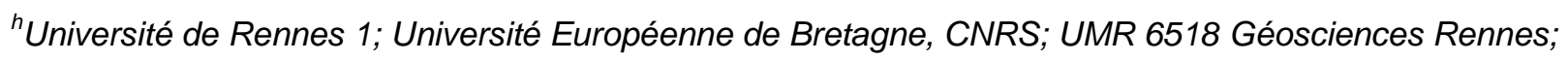
Campus de Beaulieu, Avenue du Général Leclerc, 35042 Rennes Cedex, France.

'Observatoire Volcanologique et Sismologique de Guadeloupe, IPGP, 97113 Courbeyre, La Guadeloupe, France.

* Corresponding author. Tel.: + 33169823556; fax: +33169823568

E-mail address: herve.guillou@lsce.ispl.fr

\section{Abstract}

The temporal and geochemical evolution of Marquesas hotspot volcanoes have often been interpreted with reference to the Hawaiian model, where a tholeiitic shield-building stage is followed by an alkali basaltic post-shield stage, followed after a 0.4 to $2.5 \mathrm{Myr}$ long quiescence period, by a rejuvenated basanitic/nephelinitic stage. Here we discuss geochemical data on 110 Marquesas lavas also dated using the unspiked ${ }^{40} \mathrm{~K}-{ }^{40} \mathrm{Ar}$ method on separated groundmass (including 45 new ages measured on the southern islands of Hiva Oa, Motane, Tahuata and Fatu Hiva). Sample locations were positioned on detailed geological maps to determine their shield or post-shield position with respect to the caldera collapse event(s), without taking into account their geochemical features. A rather regular decrease of the ages towards SE, consistent with the Pacific plate motion, is observed from Eiao (5.52 Ma) to Fatu Hiva (1.11 $\mathrm{Ma}$ ), and rejuvenated basanitic volcanism occurs only in Ua Huka (1.15-0.76 Ma). The occurrence of intermediate and evolved lavas is restricted to the post-caldera stage, with the exception of Eiao island. However, many other features of the Marquesas chain are rather atypical with respect to those of Hawaii. 
Although Marquesas shields are tholeiitic, several of them (Eiao, Tahuata) contain interbedded alkali basaltic and basanitic flows. Moreover, post-shield volcanoes are either alkali basalts (Ua Huka), tholeiites (Hiva Oa, Tahuata, Fatu Hiva) or both (Nuku Hiva). This feature is consistent with the temporal continuity of the two stages and the usually short length of the post-shield period $(<0.2 \mathrm{Myr})$. In a given island, the trace element and isotopic compositions of shield and post-shield lavas overlap, although both display large variations. The sources of alkali basalts and basanites are more enriched than those of the contemporaneous tholeiites. These specific features support the hypothesis of an extremely heterogeneous Marquesas plume. The "weak" character of this plume led to low partial melting degrees, which in turn resulted in the preservation in the basaltic magmas of geochemical features inherited from small-size source heterogeneities.

Keywords: Shield, Post-shield, Tholeiite, Alkali basalt, Trachyte, ${ }^{40} \mathrm{~K}-{ }^{40} \mathrm{Ar}$ age, Hotspot, Marquesas. 4

(5)

18

\section{Introduction}

The temporal evolution of plume-related oceanic intraplate volcanoes has often been investigated with reference to the classical Hawaiian model, in which four successive growth stages are distinguished (Clague and Dalrymple, 1987; Clague, 1987; Hanano et al., 2010): (1) a small volume (ca. 3\%) alkalic pre-shield stage, emplacing mostly submarine alkali basalts and basanites; (2) the main shield-building stage, during which the majority (95-98\%) of the volcano is rapidly constructed, culminating in subaerial flows of tholeiitic basalts; (3) the alkalic post-shield phase, during which small volumes (1-2\%) of alkali basalts and related intermediate/evolved lavas (hawaiites, mugearites, benmoreites and trachytes) are erupted; and finally (4) the alkalic rejuvenated stage, during which very small volumes $(<<1 \%)$ of basanites, alkali basalts and nephelinites are emplaced after a quiescence period. In the Hawaiian chain, shield tholeiitic basalts are less enriched in incompatible elements and derive from larger melting rates than the post-shield and rejuvenated alkalic lavas; in addition, the mantle sources of the latter are isotopically depleted with respect to those of the tholeiites (lower ${ }^{87} \mathrm{Sr} /{ }^{86} \mathrm{Sr}$ and ${ }^{206} \mathrm{~Pb} /{ }^{204} \mathrm{~Pb}$, higher ${ }^{143} \mathrm{Nd} /{ }^{144} \mathrm{Nd}$ : Frey et al., 1990, 2005; Shafer et al., 2005; Fekiacova et al., 2007; Garcia et al., 2010; Hanano et al., 2010).

For Hawaiian volcanoes, the main criterion used for the distinction between the shield-building and postshield stages is the change from tholeiites to alkali basalts. Indeed, Clague and Dalrymple (1987) stated (their page 7) that "the shield stage usually includes caldera collapse and eruptions of caldera-filling tholeiitic basalt. During the next stage, the alkalic postshield stage, alkalic basalt also may fill the caldera and form a thin cap of alkalic basalt and associated differentiated lava that covers the main shield". They also mentioned (their page 8) that "we have omitted the main caldera-collapse stage of Stearns (1966) from the eruption sequence because it can occur either during the shield stage or near the beginning of the alkalic postshield stage. The lava erupted may therefore be tholeiitic or alkali basalt, or of both types". 
Large major, trace element and isotopic variations in Marquesas lavas have been known for decades (Vidal et al., 1984, 1987; Duncan et al., 1986). They have been interpreted with reference to the shield/postshield Hawaiian model by several authors (Duncan et al., 1986; Woodhead, 1992; Desonie et al., 1993; Castillo et al., 2007). However, most of these works were based on the pioneer (and hence limited) sampling of Marquesas Islands made during the 1970's by R.A. Duncan (Duncan and McDougall, 1974; Duncan,

84 1975; McDougall and Duncan, 1980) and R. Brousse (Vidal et al., 1984; Brousse et al., 1990). No geological maps of the islands were available at that time, and therefore the distinction between shield and post-shield lavas was usually made using geochemical criteria. For instance, the observation that the oldest lavas from Nuku Hiva, Ua Pou and Hiva Oa are tholeiitic basalts (Duncan, 1975; Duncan et al., 1986) led Woodhead (1992) to classify hypersthene-normative Marquesas lavas as shield-related and alkali basalts/basanites as post-shield. Later, Castillo et al. (2007) studied samples collected by $\mathrm{H}$. Craig, and used ${ }^{87} \mathrm{Sr} /{ }^{86} \mathrm{Sr}(>0.7041)$ and ${ }^{143} \mathrm{Nd} /{ }^{144} \mathrm{Nd}(<0.51285)$ ratios to characterize post-shield lavas, based on the isotopic data of Woodhead (1992) obtained on R.A. Duncan's samples.

A mapping program of the Marquesas archipelago (2001-2009) led us to collect a number of new samples and draw detailed geological maps of the islands. The trace element and $\mathrm{Sr}, \mathrm{Nd}, \mathrm{Pb}$ and $\mathrm{Hf}$ isotopic features of these samples (Chauvel et al., 2012) point towards relationships between shield and post-shield lavas more complex than previously thought. Here, we use geological settings combined with unspiked ${ }^{40} \mathrm{~K}$ ${ }^{40} \mathrm{Ar}$ ages measured on groundmass and petrologic/geochemical features of this new sample set to demonstrate that the temporal evolution of the Marquesas volcanoes is rather different from that of Hawaiian volcanoes. We also discuss the constraints that they set on the corresponding plume/hotspot model.

\section{Geological setting and previous work}

\subsection{The Marquesas archipelago}

The ca. $350 \mathrm{~km}$-long Marquesas archipelago, located in northern French Polynesia, includes eight main islands (Fig. 1) that cluster into a northern group (Eiao, Nuku Hiva, Ua Huka and Ua Pou) and a southern group (Hiva Oa, Tahuata, Motane, Fatu Hiva); few islets ("motu”), banks and seamounts also exist (Fig. 1). The age of the islands decreases towards the SE (Duncan and McDougall, 1974; Brousse et al., 1990) from 5.5 Ma in Eiao to 0.6-0.35 Ma on the DH12 seamount south of Fatu Hiva (Desonie et al., 1993). However, no active volcanoes are known at the southeastern edge of the chain. ${ }^{40} \mathrm{~K}-{ }^{40} \mathrm{Ar}$ ages younger than $1 \mathrm{Ma}$ have been obtained only on $\mathrm{DH} 12$ and on the Teepoepo (1.15-0.96 Ma) and Tahoatikikau (0.82-0.76 Ma) strombolian cones on Ua Huka (Legendre et al., 2006; Blais et al., 2008). These cones were emplaced after a 1.3 Myr quiescence period, and are considered as the only example of rejuvenated volcanism in the Marquesas (Legendre et al., 2006; Chauvel et al., 2012). Most authors believe that the Marquesas Fracture Zone (MFZ; Pautot and Dupont, 1974) overlies the present position of the hotspot activity (McNutt et al., 1989; Brousse et al., 1990; Guille et al., 2002). However, the MFZ is aseismic (Jordahl et al., 1995) and no young volcanic rock has been recovered from the adjacent Marquesas Fracture Zone Ridge (MFZR; Fig. 1). The seamount chain parallel to the MFZ ridge ca. $50 \mathrm{~km}$ to the north (Fig. 1) has not yet been dredged and it could possibly mark the present location of Marquesas hotspot activity. 
The Marquesas archipelago is atypical in many respects (Brousse et al., 1990; Guille et al., 2002; Devey and Haase, 2003). It lies on an anomalously shallow (less than 4,000 m deep) 53-49 Ma old oceanic crust generated at the axis of the Pacific-Farallon ridge (Crough and Jarrard, 1981), and its crustal thickness reaches 15-20 km below the central part of the chain (Filmer et al., 1993; Caress et al., 1995). This abnormally thick crust is attributed either to underplating of plume magmas below the Moho (Caress et al., 1995; McNutt and Bonneville, 2000) or to the construction of the archipelago over a small 50-45 Ma old oceanic plateau that formed near the axis of the Pacific-Farallon ridge (Gutscher et al., 1999). In addition, the N30-40 $\mathrm{W}$ direction of the archipelago is oblique to that of the current $\mathrm{N} 65^{\circ} \mathrm{W}$ motion of the Pacific plate (Fig. 1), but parallel to the spreading axis of the Pacific-Farallon ridge prior to the current orientation of accretion along the East Pacific Rise. This feature suggests that zones of weakness in the underlying Pacific-Farallon plate might have controlled the emplacement of the Marquesas magmas (Crough and Jarrard, 1981; McNutt et al., 1989). Age-distance to the MFZR plots using the main N30-40 $\mathrm{W}$ trend of the chain and all available ${ }^{40} \mathrm{~K}-{ }^{40} \mathrm{Ar}$ ages display considerable scatter (Brousse et al., 1990; Desonie et al., 1993; Guille et al., 2002). Similar plots using the N65 W trend give better fits (Legendre et al., 2006; Chauvel et al., 2012), especially when considering only unspiked ${ }^{40} \mathrm{~K}-{ }^{40} \mathrm{Ar}$ ages measured on separated groundmass (Fig. 2), which are more accurate and reliable than conventional ${ }^{40} \mathrm{~K}-{ }^{40} \mathrm{Ar}$ data on whole rocks. Recently, Chauvel et al. (2012) showed that the chain is made of two adjacent rows of islands with distinct $\mathrm{Sr}, \mathrm{Nd}, \mathrm{Pb}$ isotopic features, delineating two isotopic stripes. At any given ${ }^{143} \mathrm{Nd} /{ }^{144} \mathrm{Nd}$ value, the northeastern row (the "Ua Huka group") has systematically higher ${ }^{87} \mathrm{Sr} /{ }^{86} \mathrm{Sr}$ and lower ${ }^{206} \mathrm{~Pb} /{ }^{204} \mathrm{~Pb}$ ratios than the southwestern row (the "Fatu Hiva group"). These rows are thought to originate from the partial melting of two adjacent filaments contained in an elongated ascending plumelet or secondary plume, rooted in a larger dome located at the base of the upper mantle (Davaille et al., 2002; Courtillot et al., 2003; Cadio et al., 2011).

The common occurrence of nested volcanoes in the Marquesas was first reported by L.J. Chubb (1930). Half of the islands (Nuku Hiva, Ua Huka, Tahuata, Fatu Hiva) are made up of a large external (outer) shield volcano with a central caldera. A younger and smaller internal (inner) post-shield volcanic edifice has grown inside this caldera. Hiva Oa comprises three adjacent shields: the larger one is unconformably overlain by post-shield flows, which also filled up part of its caldera. Ua Pou is rather unusual, because this island lacks a well-exposed outer shield and is mostly made up of phonolitic flows interbedded with basanitic and tephritic flows (Fig. 3), and crosscut by huge phonolitic spines (Legendre et al., 2005a). The two smallest islands, Eiao and Motane, represent crescent-shaped remnants of the caldera wall and external upper slopes of much larger collapsed shield volcanoes (Brousse et al., 1990; Guille et al., 2002). Therefore, the shield-building or post-shield character of a given Marquesan sample with respect to caldera collapse events

151 (see Stearns, 1966, for the case of Hawaii) can be determined using only its geological position deduced 152 from field relationships and its ${ }^{40} \mathrm{~K}-{ }^{40} \mathrm{Ar}$ age, without making any assumption based on its petrologic and 153 geochemical features. We choose this approach because no well-defined temporal change from tholeiitic to 154 alkali volcanism is observed in most Marquesas volcanoes. In the present work, we use a coherent set of 155110 lava samples to investigate the temporal geochemical evolution of the Marquesas volcanoes, with 156 special attention to the respective features of shield-building, post-shield and rejuvenated (Ua Huka) stages 157 of volcanic activity. All samples were collected during the 2001-2009 mapping program, dated by the 
unspiked ${ }^{40} \mathrm{~K}-{ }^{40} \mathrm{Ar}$ method on groundmass at Gif-sur-Yvette laboratory and analyzed for major and trace elements by ICP-AES at Plouzané (Brest) laboratory.

\subsection{Summary of the geological and geochemical features of the northern group islands}

The four islands from the northern group (Eiao, Nuku Hiva, Ua Huka and Ua Pou) were studied

163

164 previously using the same methods (Caroff et al., 1995, 1999; Legendre et al., 2005a, 2005b, 2006; Maury et al., 2006, 2009; Blais et al., 2008; Guille et al., 2010). Their volcanic successions are shown schematically in Figure 4. Below we provide a short description of their main features.

\subsubsection{Eiao}

Eiao (Maury et al., 2009) is the northernmost (Fig. 1) and largest $\left(44 \mathrm{~km}^{2}\right)$ uninhabited island in French Polynesia. It corresponds to the northwestern crescent-shaped remains of the caldera wall and of the external upper slopes of a $20 \mathrm{~km}$ large collapsed volcano. Its coastal cliffs expose a ca $400 \mathrm{~m}$ thick pile of tholeiitic basaltic flows interbedded with less common alkali basalts and crosscut by a dense network of radial dykes. Three deep core drillings have sampled the upper 1,200 $\mathrm{m}$ thick sequence of the Eiao shield, down to $-700 \mathrm{~m}$ below sea level (Caroff et al., 1995, 1999). The base of this sequence, dated at 5.52-5.48 Ma (Fig. 2), is made up of quartz-normative tholeiitic flows overlain by olivine tholeiitic flows (Fig. 3). These are in turn overlain by a ca $250 \mathrm{~m}$ thick sequence of hawaiites and mugearites, with a single intercalated trachytic flow 5.44 Ma old (Fig. 4). The middle (dated at 5.36-5.25 Ma) and upper (4.98-4.95 Ma) parts of the drilled pile are mostly made up of olivine tholeiites intercalated with picrobasaltic and alkali basaltic flows (Caroff et al., 1995, 1999; Maury et al., 2009). The old quartz tholeiites are less enriched in incompatible elements than the overlying olivine tholeiites and alkali basalts, and their $\mathrm{Sr}, \mathrm{Nd}, \mathrm{Pb}$ isotopic composition tends towards a HIMU end-member. Hawaiites and mugearites result from open-system fractional crystallization of the latter basaltic magmas, coupled with variable extents of assimilation of materials from the underlying oceanic crust (Caroff et al., 1999).

\subsubsection{Nuku Hiva}

Nuku Hiva (Legendre et al., 2005b; Maury et al., 2006) is the largest island of the archipelago $\left(339 \mathrm{~km}^{2}\right)$. It has a semicircular shape, and its northern, western and eastern parts correspond to the northern half of a huge shield, the Tekao volcano (Fig. 4). It is exclusively made up of olivine tholeiites (Fig. 2) derived from a mantle source containing a depleted MORB mantle (DMM) component. Its upper flows were emplaced between 4.01 and $3.83 \mathrm{Ma}$ according to unspiked ${ }^{40} \mathrm{~K}-{ }^{40} \mathrm{Ar}$ data (Fig. 3), although altered flows from the lower part of the exposed pile yielded ${ }^{40} \mathrm{Ar}^{39} \mathrm{Ar}$ ages ranging from 4.52 to $4.08 \mathrm{Ma}$ (Maury et al., 2006). Between 4.00 and $3.62 \mathrm{Ma}$ (unspiked ${ }^{40} \mathrm{~K}-{ }^{40} \mathrm{Ar}$ data), the Taiohae inner (post-shield) volcano grew inside the caldera of the Tekao shield, after the southern part of the latter collapsed along a $N 75^{\circ} \mathrm{E}$ trending normal fault parallel to the MFZ. This collapse event at ca $4.0 \mathrm{Ma}$ (Fig. 4) has been attributed to the lateral spreading of a weak hydrothermal zone located in the central part of the Tekao shield over an unconfined boundary, corresponding to the lower compartment of this fault (Merle et al., 2006). Mapping relationships allow us to estimate the volume of the Taiohae post-shield volcano to $45 \pm 5 \mathrm{~km}^{3}$, i.e. $28 \%$ of the emerged volume of the edifice $\left(160 \mathrm{~km}^{3}\right)$, but only $0.6 \%$ of its total volume $\left(6,950 \mathrm{~km}^{3}\right.$, Chauvel et al., 2012). Lavas 
from the Taiohae volcano include, from bottom to top: olivine tholeiites more enriched in incompatible element than those of the Tekao shield; alkali basalts and a few basanites; and large amounts of hawaiites and mugearites, which cover $47 \%$ of its surface, together with benmoreites and trachytes $(25 \%$ of its surface). In addition, parasitic vents erupted hawaiitic (3.93 Ma) and trachytic (3.92 Ma) flows on the external slopes of the Tekao shield. All the Taiohae post-shield lavas are more radiogenic in $\mathrm{Sr}$ and $\mathrm{Nd}$ and less radiogenic in $\mathrm{Nd}$ than the Tekao ones. Hawaiites and mugearites likely derived from the fractional crystallization from mafic magmas involving separation of amphibole (Legendre et al., 2005b). The isotopic signature of benmoreites and trachytes is closer to the enriched mantle II (EM II) end-member than that of mafic lavas, a feature inconsistent with simple fractionation processes.

\subsubsection{Ua Huka}

Despite its moderate size $\left(83 \mathrm{~km}^{2}\right)$, Ua Huka Island (Legendre et al., 2006; Blais et al., 2008, Chauvel et al., 2012) displays a relatively prolonged, multi-phase geological evolution. Like Nuku Hiva, it has a semicircular shape due to the collapse of the southern half of its outer shield, the Hikitau volcano. It is made up of olivine tholeiitic flows emplaced between 3.24 and 2.94 Ma. The Hane inner (post-shield) volcano was built inside the central caldera of the Hikitau shield between 2.97 and 2.43 Ma (Fig. 4). Its alkali basaltic flows derived from a spinel Iherzolite source similar to that of the Hikitau tholeiites but having experienced smaller degrees of melting (Legendre et al., 2006). Associated benmoreitic flows and trachytic and phonolitic domes were simultaneously emplaced (between 2.93 and $2.71 \mathrm{Ma}$ ) within the Hane post-shield volcano and from parasitic vents located on the outer slopes of the Hikitau shield. Then, after a $1.3 \mathrm{Myr}$ long quiescence period (Fig. 2), volcanic activity resumed, building over the inner slopes of the Hane volcano two basanitic strombolian cones, the Teepoepo (1.15-0.96 Ma) and the Tahoatikikau (0.82-0.76 Ma). Their lavas originated from temporally decreasing melting degrees of a garnet lherzolite source deeper and isotopically more depleted than that of the older Ua Huka tholeiitic and alkali basalts (Chauvel et al., 2012). The origin of this rejuvenated volcanism (the single case identified so far in the archipelago) has been attributed to a secondary melting zone located downstream the Marquesas plume (Legendre et al., 2006), similar to that envisioned by Ribe and Christensen (1999) for the Hawaiian islands. The volumes (estimated from mapping relationships) of the Hane post-shield volcano $\left(6 \pm 1 \mathrm{~km}^{3}\right)$ and the rejuvenated cones $\left(0.6 \pm 0.1 \mathrm{~km}^{3}\right)$ correspond respectively to $21 \%$ and $2 \%$ of the total emerged volume of Ua Huka $\left(28 \mathrm{~km}^{3}\right)$, and less than $0.2 \%$ only of the bulk volume of the edifice $\left(3,250 \mathrm{~km}^{3}\right)$.

The $105 \mathrm{~km}^{2}$ diamond-shaped island of Ua Pou (Legendre et al., 2005a; Guille et al., 2010) is famous 230 spectacular phonolitic spines (Ua Pou means "The Pillars" in Marquesan). Its oldest lavas are olivine tholeiite flows derived from a young HIMU-type mantle source (Duncan et al., 1986, Vidal et al., 1987). They

232 outcrop in a very small area near Hakahau village in the northeast part of the island. The base of their ca 40 $233 \mathrm{~m}$ thick pile (Guille et al., 2010) is not accessible presently but has been dated at 5.61, 4.51 and 4.46 Ma by 
234 the ${ }^{40} \mathrm{~K}^{40} \mathrm{Ar}$ method on whole rocks (Duncan et al., 1986). Its presently exposed top flow was dated at 4.00 $235 \mathrm{Ma}$ by the unspiked ${ }^{40} \mathrm{~K}-{ }^{40} \mathrm{Ar}$ method on groundmass (Legendre et al., 2005a). These Hakahau tholeiitic 236 flows are overlain either by up to $100 \mathrm{~m}$ thick laharic deposits or by trachytic and phonolitic domes dated at 2373.86 and 3.27 Ma (Guille et al., 2010). The latter sequence is in turn overlain by a strongly silica238 undersaturated lava suite forming the bulk of the island and dated between 2.95 and $2.35 \mathrm{Ma}$ (unspiked ${ }^{40} \mathrm{~K}$ -

$239{ }^{40} \mathrm{Ar}$ ages). It includes from bottom to top: (1) basanitic and tephritic lava flows with intercalated laharic 240 deposits, (2) lower phonolitic flows and intrusions, (3) basanitic and intermediate (tephritic, tephriphonolitic 241 and benmoreitic) flows with occasional interbedded phonolites, (4) upper phonolitic flows, up to $500 \mathrm{~m}$ thick, 242 and finally (5) phonolitic domes and spines, the summit of which tower several hundred meters above the 243 older units. The basanitic magmas of this suite derived from low degrees of melting of an heterogeneous 244 mantle source intermediate between EM II and HIMU end-members, and evolved towards tephritic liquids by 245 fractional crystallization (Legendre et al., 2005a). The origin of tephriphonolitic and benmoreitic magmas was ascribed to the remelting at depth of basanitic rocks, leaving an amphibole-rich residuum (Legendre et al., 2005a). These liquids evolved by either closed-system or more commonly open-system fractionation towards phonolitic and trachytic magmas.

In contrast with the other Marquesas Islands, the main Ua Pou volcanic sequence (2.95-2.35 Ma) does not include a basaltic shield. We therefore support Duncan et al.'s (1986) suggestion that the Ua Pou shield is mainly below sea level, with only its uppermost tholeiitic part presently exposed, and that the rest of the island belongs to the post-shield phase. This interpretation is supported by the occurrence of thick laharic deposits overlying the tholeiitic flows, which indicate an erosional event. However, the temporal hiatus between the shield and post-shield phases (only between 4.00 and 3.86 Ma according to Guille et al., 2010) is much shorter than that proposed by former authors: $1.58 \mathrm{Myr}$ calculated using Duncan et al.'s (1986) data and 2.34 Myr according to Woodhead (1992).

\section{New geological, geochemical and K-Ar age data on the southern Marquesas islands.}

\subsection{Methods}

The analytical techniques are identical to those used to study the northern islands. Unspiked ${ }^{40} \mathrm{~K}$ ${ }^{40} \mathrm{Ar}$ ages were obtained at the LSCE (Laboratoire des Sciences du Climat et de l'environnement) in Gif-sur-Yvette. Fresh and well-crystallized samples were selected for dating after macroscopic and microscopic inspections allowing us to check the lack of post-magmatic mineral phases. In addition, the degree of alteration of these samples was estimated from their loss on ignition value (LOI). For 40 out of 45 dated samples (Tables 2 and 4 ) LOI ranges from -0.39 to 1.56 wt $\%$ and these samples are considered as essentially unaltered. The 5 other samples (HV81, HV99, MT11,TH35 and FH30) have LOI between 1.90 and 2.77 wt\%. Despite their higher LOI, we selected them because of their critical geological position or their unusual composition (tephriphonolitic sample TH35). The samples were crushed and sieved to $0.250-0.125 \mathrm{~mm}$ size fractions, and ultrasonically washed in acetic acid $(1 \mathrm{~N})$ during 45 minutes at a temperature of $60^{\circ} \mathrm{C}$ to remove unsuspected minute amounts of secondary mineral phases. Potassium and argon were measured on the microcrystalline groundmass, after removal of phenocrysts using heavy liquids and magnetic separations. This process removes at least 
some potential sources of systematic error due to the presence of excess ${ }^{40} \mathrm{Ar}$ in olivine and feldspar phenocrysts (Laughlin et al., 1994). The K content of the separated groundmass was measured by ICP-AES in Plouzané using the same method as for major elements while Ar analyses were performed in Gif-sur-Yvette using the procedures of Guillou et al. (2011). Ages given in Tables 1 and 3 were calculated using the constants recommended by Steiger and Jäger (1977). Unspiked K-Ar analysis of each sample involved three independent determinations of potassium and two of argon. Based on replicate analysis of material references, the potassium concentrations were determined with an uncertainty of $1 \%(1 \sigma)$. These potassium concentrations were averaged to yield a mean value. Age determinations of each sample were made using this mean value and the weighted mean of the two independent measurements of ${ }^{40} \mathrm{Ar}^{*}$ (radiogenic argon). Analytical uncertainties for the Ar data are $1 \sigma$, and consist of propagated and quadratically averaged experimental uncertainties arising from the ${ }^{40} \mathrm{Ar}$ (total) and ${ }^{40} \mathrm{Ar}{ }^{*}$ determinations (see Westaway et al., 2005 for more details). Uncertainties on the ages are given at $2 \sigma$.

Before chemical analyses, all samples were crushed using an agate mortar. Major and trace element data (Tables 2 and 4) were obtained by Inductively Coupled Plasma-Atomic Emission Spectrometry (ICPAES) at IUEM, Plouzané using the method of Cotten et al. (1995). The international standards used for calibration were ACE, BEN, JB-2, PM-S and WS-E and the relative standard deviations are $\pm 1 \%$ for $\mathrm{SiO}_{2}$, and $\pm 2 \%$ for other major elements except $\mathrm{P}_{2} \mathrm{O}_{5}$ and $\mathrm{MnO}$ (absolute precision $\pm 0.01 \%$ ). Samples were classified according to their position in the TAS diagram (Fig. 3). Within the basalt group, silica-saturated or oversaturated lavas (normative hy + ol or $h y+Q$ ) were called tholeiitic basalts while nepheline-normative samples were called alkali basalts (normative compositions given in Tables 2 and 4). Some tholeiitic basalts plot close to or even above the Macdonald and Katsura's (1964) boundary in Figure 3 and could therefore be considered as transitional basalts. We did not include the latter category in our classification chart because it has not been previously used in the Marquesas and is not defined rigorously.

\subsection{Hiva Oa}

Hiva Oa $\left(320 \mathrm{~km}^{2}\right)$, the second largest Marquesas island and the highest one (1276 $\mathrm{m}$ at Mt Temetiu), has a WSW-ENE elongated shape parallel to the MFZ (Fig. 1). New field data (Fig. 5) combined with 20 new unspiked ${ }^{40} \mathrm{~K}-{ }^{40} \mathrm{Ar}$ ages (Table 1) show that the island consists in four coalescent volcanoes whose age decreases eastwards from $2.55 \pm 0.05$ to $1.46-1.44 \pm 0.03 \mathrm{Ma}$ (Figs. 4 and 5). All of them are made up of tholeiitic basalts, some of which display a transitional affinity, and hawaiites (Table 2). Alkali basalts and basanites were not identified in our set of 87 newly collected samples (Maury et al., 2012) nor in previous samplings by R. Brousse (Chauvel et al., 2012, their Supplementary file D). Mugearites, benmoreites and trachytes (Table 2) occur only in the post-shield Ootua volcano, or as dykes and plugs crosscutting the Puamau shield.

The oldest volcano, Taaoa, is located on the western coast of Hiva Oa (Fig. 5). It represents the crescent-shaped remnants of a largely collapsed shield, which are unconformably overlain by the flows of the much bigger Temetiu shield. The Taaoa edifice is formed by a monotonous pile of meter-thick tholeiitic 
313 village, was dated at $2.55 \pm 0.05 \mathrm{Ma}$ (HV64, Table 1 and Fig. 4). Taaoa basalts have lower K contents, lower $314{ }^{87} \mathrm{Sr} /{ }^{86} \mathrm{Sr}$ and higher ${ }^{206} \mathrm{~Pb} /{ }^{204} \mathrm{~Pb}$ ratios compared to all other Hiva Oa basalts, and their trace element and 315 isotopic signatures are closer to HIMU (Chauvel et al., 2012). They plot within the "Ua Pou" trend unlike all 316 other lavas that plot in the "Ua Huka" trend. Accordingly, the $\mathrm{N} 65^{\circ} \mathrm{W}$ limit between the two isotopic stripes defined by Chauvel et al. (2012) has been set at Taaoa village.

The Temetiu shield (Fig. 5) is the largest volcano of Hiva Oa. It is made of a more than 1,200 m thick pile of meter-thick quartz or olivine normative tholeiites and hawaiites (Table 2). The construction of its exposed part started around 2.27 $\pm 0.05 \mathrm{Ma}$ (HV87, foot of Mt Temetiu) and 2.25 $\pm 0.05 \mathrm{Ma}$ (HV84, northern slopes near Hanaiapa village). Its major activity occurred between $2.13 \pm 0.05$ and $1.91 \pm 0.04 \mathrm{Ma}$, based on seven unspiked ${ }^{40} \mathrm{~K}-{ }^{40} \mathrm{Ar}$ ages (Table 1 and Fig. 4). Its well-exposed semicircular caldera facing south collapsed before $2.01 \mathrm{Ma}$. Indeed, this event was followed by landslides which generated avalanche and debris flow deposits, later crosscut by a number of dykes, including HV99 (2.01 $\pm 0.04 \mathrm{Ma})$ south of Atuona village. Volcanic activity of the Temetiu shield ended at $1.83 \pm 0.04 \mathrm{Ma}$ (sample HV81 north of Hanapaaoa village). It was almost immediately followed by the emplacement at $1.80 \pm 0.04 \mathrm{Ma}$ (sample HV65) of a thick pile of post-shield tholeitic flows (the Atuona flows) within the caldera, east and north of Atuona village. Temetiu shield and Atuona post-shield tholeiitic flows share the same isotopic signature typical of the "Ua Huka" stripe (Chauvel et al., 2012). The origin of the collapse of the southern part of these edifices is attributed to the lateral spreading of an hydrothermal zone located beneath the Temetiu caldera over an unconfined boundary corresponding to the lower compartment of a fault parallel to the MFZ (Maury et al., 2013), such as in the case of Nuku Hiva.

The Puamau shield forms the eastern part of Hiva Oa (Fig. 5). Its lower part is made up of an up to 500 $\mathrm{m}$ thick pile of meter-thick flows of quartz tholeiites, olivine tholeiites and interbedded hawaiites dipping gently towards the Temetiu shield or the southern coast. They are dated at $1.65 \pm 0.04$ (HV70) and $1.62 \pm$ $0.04 \mathrm{Ma}$ (HV62). They are overlain by a $200 \mathrm{~m}$ thick pile of tholeiitic basalts and minor interbedded hawaiites occurring as thicker (5-20 m) and usually columnar-jointed flows (Puamau shield upper flows in Fig. 5). Although this unit is younger ( $1.46 \pm 0.03 \mathrm{Ma}$, sample HV88) than the main shield, we do not consider it as belonging to the post-shield stage. Indeed, both were affected by the collapse event that led to a caldera open NE, with its center near the village of Puamau (Fig. 5). Post-caldera volcanic edifices have not been identified within this caldera, but several small benmoreitic and trachytic dykes and plugs (not shown in the simplified geologic map of Fig. 5) crosscut the Puamau shield pile. They are usually altered and therefore unsuitable for ${ }^{40} \mathrm{~K}-{ }^{40} \mathrm{Ar}$ dating.

The Ootua post-shield edifice was emplaced on the eastern slopes of the Temetiu shield. Its central unit, ca $200 \mathrm{~m}$ thick, is exclusively made up of intermediate (mugearitic, benmoreitic and phonotephritic) and silica-oversaturated trachytic flows and N-S trending dykes. It culminates at Mt Ootua, a $500 \mathrm{~m}$ wide and $200 \mathrm{~m}$ high columnar-jointed dome of quartz normative trachyte. This unit is dated at $1.73 \pm 0.04 \mathrm{Ma}$ (HV56 mugearitic flow) and $1.64 \pm 0.03 \mathrm{Ma}$ (HV54 benmoreitic dyke). Its peripherical unit consists of an up to 400 $\mathrm{m}$ thick pile of fissure erupted tholeiitic and hawaiitic flows. Most of these flows display well-developed basal

350 autoclastic breccias. They flow over either (1) the northern and southern slopes of the Temetiu shield, (2) its 351 caldera within which they overlie the Atuona post-shield flows, and finally (3) towards the topographic trough 
separating the Temetiu and Puamau shields (Fig. 5). They fill most of this trough, flowing either towards the northern coast or the southern coast where a tholeiitic basalt (HV107) yields the youngest age measured in Hiva Oa $(1.44 \pm 0.03 \mathrm{Ma})$. Another young age of $1.51 \pm 0.03 \mathrm{Ma}$ has been obtained on an hawaiitic flow (HV86) overlying the Temetiu shield.

The volumes (estimated from mapping relationships) of the Atuona and Ootua post-shield lavas (14 \pm 1 $\mathrm{km}^{3}$ ) correspond to $9.5 \%$ of the total emerged volume of Hiva Oa $\left(145 \mathrm{~km}^{3}\right)$, and $0.2 \%$ of the bulk volume of the edifice $\left(6,900 \mathrm{~km}^{3}\right.$, Chauvel et al., 2012).

\subsection{Motane and Tahuata}

Motane (Figs. 1 and 5) is a small $\left(13 \mathrm{~km}^{2}\right)$ crescent-shaped uninhabited island located southeast of Hiva $\mathrm{Oa}$ and east of Tahuata. Like Eiao, it corresponds to a sector of the caldera wall (up to $500 \mathrm{~m} \mathrm{high}$ ) and the upper external slopes of a largely collapsed shield volcano. It is made up of a monotonous pile of meterthick quartz and olivine tholeiitic flows, interbedded with picrobasalts and minor hawaiites. This pile is crosscut by a dense network of radial dykes, which include alkali basalts and basanites (Fig. 4) displaying incompatible element patterns more fractionated than those of the tholeiites. Two tholeitic flows from the middle part of the pile are dated at $1.59 \pm 0.04 \mathrm{Ma}$ (MT04, altitude $120 \mathrm{~m}$ ) and $1.53 \pm 0.03 \mathrm{Ma}$ (MT08, altitude $190 \mathrm{~m}$ ) (see Table 3). An alkali basaltic dyke collected at sea level yields an older age (1.96 \pm 0.04 $\mathrm{Ma}, \mathrm{MT11}$ in Table 3) that is barely consistent with the others and may indicate sample contamination by seawater (also consistent with its relatively high LOI of $2.53 \mathrm{wt} \%$ ). The isotopic $\mathrm{Sr}, \mathrm{Nd}, \mathrm{Pb}$ compositions of tholeiites MT04 and MT08 are typical of the "Ua Pou" stripe (Chauvel et al., 2012), as well as that of basanitic sample MT12 that is clearly more radiogenic in $\mathrm{Sr}$ and less radiogenic in $\mathrm{Nd}$ than the tholeiites.

Tahuata $\left(69 \mathrm{~km}^{2}\right)$ corresponds to the northwestern half of a large shield known as the Vaitahu shield (Maury et al., 2013). Its southern part has collapsed over an unconfined boundary. The latter probably corresponds to the SE down-faulted block, lowered by $1,000 \mathrm{~m}$, of a major $\mathrm{N} 35^{\circ} \mathrm{E}$ fault lineament wellidentified off the SE coast of the island (Maury et al., 2013). This collapse event led to the formation of an 8 km large caldera opened toward SE (Fig. 5). A small edifice, the inner Hanatetena volcano (Figs. 4 and 5) grew inside this caldera. The caldera wall was later affected by large landslides, which generated an up to $300 \mathrm{~m}$ thick pile of avalanche and debris flow deposits. The latter partly filled up the topographic trough separating the foot of the caldera wall from the Hanatetena post-shield edifice.

The $700 \mathrm{~m}$ thick lower unit of the Vaitahu shield consists of meter-thick basaltic and hawaiitic flows. The unspiked ${ }^{40} \mathrm{~K}-{ }^{40} \mathrm{Ar}$ ages (Table 3) indicate that it was emplaced rather quickly, between $2.11 \pm 0.05 \mathrm{Ma}$ (TH39 tholeiitic basalt, western coast south of Hapatoni village) and $1.81 \pm 0.04 \mathrm{Ma}$ (TH14 alkali basalt, northern coast). Three ages clustering around $1.90 \mathrm{Ma}$ (TH37, TH38 and TH18 tholeiitic basalts, central part of the island) may record the paroxysmal event. This lower unit is overlain by a pile of thick $(>10 \mathrm{~m})$ and usually columnar-jointed tholeiitic flows. This upper unit forms the central ridge of the island, and is up to 500 $\mathrm{m}$ thick. Its basal flow has an age of $1.88 \pm 0.04 \mathrm{Ma}$ (TH13). We consider it as the upper part of the Vaitahu shield, because (1) it conformably overlies the top of the lower unit, (2) its age is similar to that of the main 
building phase of the lower unit between $1.91 \pm 0.04$ and $1.88 \pm 0.04 \mathrm{Ma}$, and (3) it was obviously affected by the caldera collapse event, as it forms presently the uppermost slopes of the caldera wall (Fig. 5).

A specific feature of the Vaitahu shield is its chemical heterogeneity. It is mostly tholeiitic (18 quartz tholeiites and olivine tholeiites in our sample set), but also includes alkali basalts (2 samples), basanites (3 samples) and hawaiites ( 3 samples). Alkali basalts and basanites are more sodic and more enriched in the most incompatible elements compared to the tholeiites (Table 4), and they display consistently higher ${ }^{87} \mathrm{Sr} /{ }^{86} \mathrm{Sr}$ and lower ${ }^{143} \mathrm{Nd} /{ }^{144} \mathrm{Nd}$ and ${ }^{206} \mathrm{~Pb} /{ }^{207} \mathrm{~Pb}$ ratios according to data obtained on the same samples (Chauvel et al., 2012).

The small (less than $200 \mathrm{~m}$ high) post-caldera Hanatetena volcano is composed exclusively of tholeiitic and hawaiitic flows. The basal flows display pahoehoe and lava tube features; they are overlain by highly weathered flows of meter thickness. Their trace element and isotopic compositions plot within the range of the Vaitahu shield tholeiites (Chauvel et al., 2012). Two flows are dated at $1.80 \pm 0.04 \mathrm{Ma}$ (TH31) and $1.74 \pm$ $0.04 \mathrm{Ma}$ (TH8). The exposed volume of the Hanatetena edifice $\left(0.5 \pm 0.1 \mathrm{~km}^{3}\right)$ represents only $2 \%$ of the volume of Tahuata island $\left(25 \mathrm{~km}^{3}\right)$.

The single intermediate/evolved lava documented in Tahuata is a columnar-jointed tephriphonolitic spine, $200 \mathrm{~m}$ in diameter, which crosscuts the northern slopes of the Vaitahu shield and forms the summit of Mt Tumu Meae Ufa $(1,050 \mathrm{~m})$. Because of its young age (1.78 $\pm 0.04 \mathrm{Ma}$, sample TH35), we relate its emplacement to the post-shield stage.

\subsection{Fatu Hiva}

Fatu Hiva Island $\left(84 \mathrm{~km}^{2}\right)$ displays a typical semicircular shape. It includes an external (outer) shield, the Touaouoho volcano, truncated by a $8 \mathrm{~km}$ wide caldera opening westwards, inside which grew a smaller post-caldera edifice, the Omoa volcano (Fig. 5). As in Tahuata, the caldera wall was affected by landslides which generated avalanche and debris flow deposits up to $250 \mathrm{~m}$ thick. These deposits now outcrop within the topographic trough separating the outer shield from the inner Omoa post-shield edifice. The drowning of the western half of the island and the development of the caldera are probably related to major sector collapse events, marked in the regional bathymetry by a $15 \mathrm{~km}$ wide trough (at 2,500 m depth) located west of Fatu Hiva, downslope from the Omoa volcano.

The Touaouoho shield has an up to $1,100 \mathrm{~m}$ thick rather monotonous pile of meter-thick flows of olivine tholeiites, tholeiitic picrobasalts and minor hawaiites (Table 4), crosscut by a dense network of radial inframetric tholeiitic dykes. Their unspiked ${ }^{40} \mathrm{~K}-{ }^{40} \mathrm{Ar}$ ages (Table 3) range from $1.81 \pm 0.04 \mathrm{Ma}$ (FH13) to 1.35 $\pm 0.03 \mathrm{Ma}$ (FH18). The Omoa post-caldera edifice is composed of a $700 \mathrm{~m}$ thick pile of inframetric tholeitic flows, with lava tubes in pahoehoe composite flows. Their ages (Table 3) range from $1.43 \pm 0.03 \mathrm{Ma}$ (FH08)

422 to $1.23 \pm 0.04 \mathrm{Ma}$ (FH05). In addition, a tholeiitic dyke (FH30) crosscutting the debris flow deposits at 423 Hanavave village yielded an age of $1.41 \pm 0.03 \mathrm{Ma}$, consistent with the end of volcanic activity in Touaouoho 424 shield and the initiation of that of the post-shield Omoa edifice. These two stages led to the emplacement of 425 rather similar tholeiitic basalts and hawaiites (Table 4). Their major, trace element (Table 4) and isotopic Sr 
$\mathrm{Nd} \mathrm{Pb}$ and $\mathrm{Hf}$ compositions largely overlap, and both are typical of the predominantly EM II-HIMU sources of the southwestern trend, which has been labelled the "Fatu Hiva group" (Chauvel et al., 2012).

The youngest Fatu Hiva lavas are two well-preserved trachytic domes (Figs. 4 and 5) crosscutting and overlying the Touaouoho shield flows on the northern coast (FH16, $1.11 \pm 0.02 \mathrm{Ma}$ ) and east of Omoa village (FH06, $1.22 \pm 0.03 \mathrm{Ma}$ ). In addition, a $15 \mathrm{~m}$ wide trachytic dyke (FH12) crosscutting the basal flows of Omoa post-shield edifice is dated at $1.38 \pm 0.03 \mathrm{Ma}$, and was therefore emplaced during the post-shield stage. The volumes (estimated from mapping relationships) of the Omoa post-shield lavas $\left(5 \pm 1 \mathrm{~km}^{3}\right)$ correspond to $28 \%$ of the total emerged volume of Fatu Hiva $\left(28 \mathrm{~km}^{3}\right)$, and $0.2 \%$ only of the bulk volume of the edifice $\left(2,800 \mathrm{~km}^{3}\right)$.

\section{Discussion}

\subsection{Timing of eruptions: no gap between shield-building and post-caldeira stages}

The new unspiked ${ }^{40} \mathrm{~K}-{ }^{40} \mathrm{Ar}$ ages plotted against the distances of the islands to the MFZR along the $\mathrm{N} 65^{\circ} \mathrm{W}$ direction of movement of the Pacific plate (Fig. 2) are reasonably consistent with its local motion rate of $10.5 \mathrm{~cm} /$ year, as previously pointed out by Legendre et al. (2006). These new ages display much less scatter than the age-distance to the MFZR plots using the main $\mathrm{N} 30-40^{\circ} \mathrm{W}$ trend of the chain and all the available ${ }^{40} \mathrm{~K}-{ }^{40} \mathrm{Ar}$ ages measured on bulk rocks (Brousse et al., 1990; Desonie et al., 1993; Guille et al., 2002). The dashed line in Fig. 2, which corresponds to distances to the unexplored seamount chain located ca $50 \mathrm{~km}$ north of the MFZR (Fig. 1), provides a better fit to the start of activity in some islands. Thus, this seamount chain is a strong candidate for the present-day location of the Marquesas hotspot. Overall, Ua Huka differs from all the other islands by the fact that the emplacement of the exposed part of its shield started clearly later than predicted by the hotspot hypothesis (Fig. 2). It is also the only Marquesas Island showing a rejuvenated volcanic stage (Legendre et al., 2006).

Data plotted in Figures 2 and 4 show that there is no consistent temporal hiatus between the shieldbuilding and post-caldeira activities. Usually the two stages either slighly overlap (Nuku Hiva, Ua Huka, Fatu Hiva) or the gap between them is within the range of analytical uncertainties (Temetiu shield and Atuona post-caldeira lavas in Hiva Oa, Tahuata). In Ua Pou, a marginal hiatus (Guille et al., 2010) is observed between the youngest shield tholeiitic basalt $(4.00 \pm 0.06 \mathrm{Ma})$ and the oldest post-shield phonolite $(3.86 \pm 0.06$ Ma). However, this might be due to sampling bias because of the very small size of the emergent part of the shield that is mostly overlain by lahar deposits. Such a temporal continuity implies that the growth of postshield edifices started immediately after the main caldera collapse event, while eruptive activity was still occurring at least in some parts of the shield volcano. Another striking feature of the data shown in Figure 2 is that contemporaneous volcanism occurred in islands located more than $100 \mathrm{~km}$ away from each other (Fig. 1), e.g. around 2.5 Ma (Ua Huka, Ua Pou, Hiva Oa) or between 2.0 and $1.5 \mathrm{Ma}$ (Hiva Oa, Tahuata, Motane and Fatu Hiva). This feature is consistent with a "classical" plume model involving a $200 \mathrm{~km}$ large summital melting zone (Farnetani and Hoffmann, 2010), and it is also observed in other hotspot-related islands such as the Hawaiian chain (Clague and Dalrymple, 1987), the Society archipelago (Guillou et al., 2005) and the Canaries (Carracedo et al., 1998). However, rejuvenated volcanism is much less common in 
the Marquesas (Ua Huka) than in the Hawaiian chain, the Canaries, Mauritius (Paul et al., 2005) and Samoa (Konter and Jackson, 2012).

\subsection{Evidence for post-shield emplacement of nearly all the intermediate and evolved lavas}

The TAS diagram (Fig. 3) and the age versus $\mathrm{SiO}_{2}$ plot (Fig. 6) show that nearly all the dated lavas more evolved than tholeiitic and alkali basalts, basanites and hawaiites were erupted during the post-shield stage of Marquesan volcanoes. These include rare tephrites (Ua Pou), mugearites (Hiva Oa), benmoreites (Nuku Hiva, Ua Pou, Hiva Oa) and tephriphonolites (Ua Pou, Tahuata), and more abundant trachytes (Nuku Hiva, Ua Huka, Ua Pou, Hiva Oa, Fatu Hiva) and phonolites (Ua Pou, Ua Huka). The only exception is Eiao, in which coring has recovered a $10 \mathrm{~m}$ thick trachytic flow in the Dominique drill hole (Caroff et al., 1995; Maury et al., 2009), at depths of 462 to $472 \mathrm{~m}$ below sea level. It has been dated at $5.44 \pm 0.04 \mathrm{Ma}$, an age perfectly consistent with its position within the Eiao shield pile. This trachyte represents only a very small fraction of the 2,100 $\mathrm{m}$ long cored volcanic sequences recovered from the three Eiao deep drillings. However, mugearites (undated) also occur in the three cored sequences, in which they have a total thickness of ca 70 $\mathrm{m}$ (Maury et al., 2009). The origin of Eiao mugearites and trachytes has been ascribed to open-system fractional crystallization of associated alkali basaltic magmas, coupled with assimilation of the oceanic crust underlying the shield (Caroff et al., 1999).

In the other islands, the intermediate and evolved lavas erupted within the post-shield volcanoes (Nuku Hiva, Ua Huka, Ua Pou, Ootua edifice in Hiva Oa). However, some of them outcrop as parasitic domes, spines, plugs or dykes crosscutting the older (outer) volcanic shields: trachytes in Nuku Hiva, Ua Huka, Hiva Oa (within the Puamau shield) and Fatu Hiva, and the tephriphonolitic spine of Mt Tumu Meae Ufa in Tahuata. In Nuku Hiva, Ua Huka and Ua Pou, these trachytes or phonolites and the associated intermediate lavas outcrop together with alkali basalts and/or basanites. Their ${ }^{40} \mathrm{~K}-{ }^{40} \mathrm{Ar}$ ages fall within the range of those of the latter or are slightly younger. In the case of Nuku Hiva, petrogenetic studies (Legendre et al., 2005b) led to the conclusion that trachytes derived from open system fractional crystallization of alkali basalt magmas coupled with assimilation of enriched oceanic crust with an EM II signature. The origin of the unusually abundant phonolites from Ua Pou is thought to result from the fractionation of tephriphonolitic and benmoreitic magmas derived from the remelting of basanitic rocks (Legendre et al., 2005a). In Fatu Hiva, the emplacement of trachytes was contemporaneous with or post-dated that of post-caldera tholeiitic basalts, but the possible petrogenetic relationships between them have not been investigated. The same situation pertains to the Ootua post-shield volcano in Hiva Oa, where a spatial and temporal association of tholeiitic basalts (some of which display a transitional affinity), hawaiites, mugearites, benmoreites and trachytes is exposed (Maury et al., 2013). Evolved lavas were emplaced during the known entire history of the archipelago (Fig. 6): Eiao trachyte is one of the oldest lavas of our set of data and Fatu Hiva ones count among the youngest. Nuku Hiva and Ua Huka trachytes as well as the very abundant Ua Pou phonolites were emplaced between ca 4.0 and $2.5 \mathrm{Ma}$ (Fig. 6).

\subsection{Chemical diversity of shield and post-shield basaltic lavas}

In the Hawaiian model, basaltic magmas derive from temporally decreasing melt fractions of the mantle sources: the emplacement of tholeiitic shield basalts is followed by that of post-shield alkali basalts and then 
503 by rejuvenated basanites or nephelinites, and $\mathrm{Sr}$ isotopic ratios decrease during this evolution (Garcia et al., 504 2010; Hanano et al., 2010). In the Marquesas, Ua Huka island volcanism followed this trend, with the 505 successive emplacement of Hikitau shield tholeiites, Hane post-shield alkali basalts and associated 506 benmoreites, trachytes and phonolites, and finally Teepoepo and Tahoatikikau rejuvenated basanitic cones. 507 However, Hikitau and Hane basalts display similar radiogenic $\mathrm{Sr}$ isotopic compositions, and only the 508 basanites from the rejuvenated cones are less radiogenic (Chauvel et al., 2012). In Ua Pou, the small 509 emergent remnants of an HIMU-type tholeiitic shield are overlain by a thick post-shield pile of basanites, 510 phonolites and other silica-undersaturated lavas more radiogenic in $\mathrm{Sr}$, with a dominant EM II signature 511 (Duncan et al., 1986; Vidal et al., 1987; Legendre et al., 2005a).

512 The temporal petrologic evolution of other islands is more complex. Most shield lavas are tholeiitic, but 513 minor amounts of alkali basalts and basanites displaying higher enrichments in incompatible elements and 514 more radiogenic $\mathrm{Sr}$ isotopic ratios are interbedded with them in the shields of Eiao and Tahuata, or occur as 515 dykes crosscutting them in the Motane shield. In Nuku Hiva, the large post-shield Taiohae volcano includes 516 olivine tholeiites, alkali basalts and basanites more radiogenic in Sr than the Tekao shield tholeiites 517 (Legendre et al., 2005b). Post-shield basaltic lavas are exclusively tholeiitic or transitional in Hiva Oa 518 (Atuona and Ootua units), Tahuata (Hanatetena) and Fatu Hiva (Omoa). Although displaying a rather large 519 isotopic variability, they fall within the range of shield tholeiites from the same islands (Chauvel et al., 2012).

520 As a whole, the claim by Woodhead (1992) and Castillo et al. (2007) that Marquesas shield lavas have 521 systematically lower ${ }^{87} \mathrm{Sr} /{ }^{86} \mathrm{Sr}$ ratios than post-shield lavas is not supported by isotopic studies conducted on 522 our sample set (Chauvel et al., 2012). This conclusion applies to islands from the two isotopic groups, e.g. to 523 Eiao and Ua Huka in the "Ua Huka group" and Hiva Oa, Tahuata and Fatu Hiva in the "Fatu Hiva group" 524 (Chauvel et al., 2012). The isotopic features of the sources of the Marquesas lavas are therefore not related 525 to the temporal pattern of volcanism (shield/post-shield activities) in a given island. The mafic lavas from the 526 two groups display similar La/Yb ratios (Fig. 7), while the Ua Huka rejuvenated basanites exhibit higher 527 ones. Post-shield intermediate and evolved lavas are more scattered in Fig. 7, probably because of their 528 complex petrogenesis (open-system fractionation or remelting of mafic magmas). In a similar La/Yb versus 529 La plot in which samples are sorted by petrographic type, alkali basalts display La/Yb ratios higher than 530 those of tholeiites (Chauvel et al., 2012, their Figure 6).

\section{$531 \quad$ 4.4. Implications for Marquesas plume heterogeneity and hotspot models}

$532 \quad$ Hotspot models previously proposed for the Marquesas (Duncan et al., 1986; Woodhead, 1992; Desonie 533 et al., 1993; Castillo et al., 2007) involved melting of a heterogeneous zoned mantle plume and of the 534 overlying oceanic lithosphere, or interactions between ascending plume-derived melts and this lithosphere. 535 These models were based on the assumption that the archipelago followed an "Hawaiian-type" temporal 536 evolution, the main difference being that in the Marquesas shield tholeitic basalts were less radiogenic in $\mathrm{Sr}$ 537 (closer to DMM and/or HIMU) than the post-shield alkalic lavas (closer to EM end-members). In addition, 538 some authors used the tholeitic or alkalic compositions of the basalts (Woodhead, 1992) or even their Sr 539 isotopic ratios (Castillo et al., 2007) to classify them as shield or post-shield, which led to additional 540 confusion. 
In the present study and in the Chauvel et al. paper (2012), we used exclusively geological (field relationships determined from detailed mapping) and chronological (unspiked ${ }^{40} \mathrm{~K}-{ }^{40} \mathrm{Ar}$ ages) data to determine the shield or post-shield position of the samples. Our results show that: (1) there was usually no temporal gap between shield and post-shield activities at a given island;

(2) eruptions occurred simultaneously in islands distant as much as $100 \mathrm{~km}$ one from another; (3) although most shields are tholeiitic, several of them (Eiao, Tahuata) contain interbedded alkali basaltic and basanitic flows; (4) while post-shield intermediate and evolved lavas derive usually from alkali basaltic or basanitic magmas, several post-shield volcanoes are tholeiitic (Hiva Oa, Tahuata, Fatu Hiva); (5) the trace element and isotopic compositions of shield and post-shield tholeiites display large variations, but the two groups overlap in most diagrams (Chauvel et al., 2012); and finally (6) the "Ua Huka" and "Fatu Hiva" isotopic groups involve mixtures of different mantle components, all of them likely located within the plume itself (Chauvel et al., 2012) as also envisioned for Hawaii (Frey et al., 2005; Fekiacova et al., 2007; Garcia et al., 2010; Hanano et al., 2011).

The $\mathrm{Sr}$ and $\mathrm{Nd}$ isotopic differences between tholeiitic basalts and alkali basalts/basanites from Marquesas Islands are shown in Figure 8. This plot shows all the data from the GEOROC database on basaltic lavas whose major element and isotopic data were available. The sources of alkali basalts and basanites are generally more enriched than those of the tholeiites at the scale of the archipelago. This is also true within a given island, although the isotopic contrasts range from huge at Ua Pou to large at Tahuata, Nuku Hiva, and Motane and small at Eiao and Ua Huka. These contrasts are consistent with the hypothesis of an extremely heterogeneous character of the Marquesas plume. The nearly contemporaneous emplacement of tholeiites and alkali basalts with different isotopic compositions in Tahuata (Chauvel et al., 2012) suggests the occurrence of heterogenous mantle domains $10 \mathrm{~km}$ or less in diameter, as envisioned for several other plumes including Hawaii (Marske et al., 2007; Hanano et al., 2010), Mauritius (Paul et al., 2005) and the Galápagos (Gibson et al., 2012). When affected by the same high thermal regime in the central part of a plume, domains with contrasted lithologies could experience variable degrees of melting, generating the observed diversity of basaltic magmas. Especially, low-degree melts might sample preferentially fertile (and isotopically enriched) pyroxenite while the signature of the more depleted peridotitic source dominates in high-degree melts (Sobolev et al., 2005, 2007; Jackson and Dasgupta, 2008; Day et al., 2009; Dasgupta et al., 2010; White, 2010; Davis et al., 2011; Herzberg, 2011).

The occurrence of tholeiitic post-shield basalts in several islands is not surprising given the temporal continuity between the shield and post-shield stages and the usually short period of emplacement of these post-shield tholeiites ( $<0.1 \mathrm{Ma}$ in Tahuata, Nuku Hiva and for Ootua basaltic flows in Hiva Oa; 0.2 Ma in Fatu Hiva, Fig. 5 and Tables 1 and 3). It is likely that during such short time spans the extent of melting of the plume at depth did not change significantly, while the volcano structure was considerably modified after the caldera collapse event. Longer post-shield activities might record a decrease of melting and possible preferential sampling of enriched materials. In the Taiohae inner edifice (Nuku Hiva) where post-shield activity lasted ca $0.4 \mathrm{Ma}$ (from 4.00 to $3.62 \mathrm{Ma}$; Maury et al., 2006), a brief tholeiitic episode was followed by the emplacement of alkali basalts and basanites, and then by that of mugearites, benmoreites and trachytes derived from an enriched mantle source. A rather similar evolution has been documented in the post-shield volcanism of Mauna Kea, Hawaii (Frey et al., 1990), where the initial emplacement of tholeiites and alkali 
basalts (basaltic substage) was followed by that of intermediate and evolved lavas (hawaiitic substage). Finally, the emplacement of the rejuvenated basanitic strombolian cones in Ua Huka after a 1.3 Myr long quiescence period (Fig. 2) was accompanied by major petrogenetic changes, involving very low melting degrees of a garnet Iherzolite source deeper and isotopically more depleted than that of the older tholeitic and alkali basalts (Legendre et al., 2006).

The petrologic and geochemical diversity of Marquesas lavas is rather exceptional given the modest size of the archipelago, as appreciated since the pioneer works of A. Lacroix (1928) and L.J. Chubb (1930). It can be related to the "weak" character of the Marquesas plume (McNutt et al., 1989), which produced "only" 7,700 km $\mathrm{km}^{3}$ of magma per Myr in the Marquesas (Chauvel et al., 2012), compared to $213,000 \mathrm{~km}^{3}$ for the Big Island of Hawaii (Robinson and Eakins, 2006). Indeed, low degrees of partial melting resulted in the preservation in the Marquesas basaltic magmas of geochemical features inherited from small-size source heterogeneities, while high degrees of partial melting and resulting high magma production rate tend to blend these features. The complex petrogenesis (open-system processes or remelting of mafic precursors) of post-shield intermediate and evolved lavas contributed further to increase this diversity.

\section{Conclusions}

The study of 110 Marquesas lavas located on detailed geological maps and dated by the unspiked ${ }^{40} \mathrm{~K}$ ${ }^{40} \mathrm{Ar}$ method on separated groundmass allows us to demonstrate that the temporal evolution of the archipelago is rather different with respect to that of Hawaii and many other hotspot-related chains. There is usually no temporal gap between shield and post-shield activities in a given island, and rejuvenated volcanism is uncommon. Although most shields are tholeiitic, several of them (Eiao, Tahuata) contain interbedded alkali basaltic and basanitic flows. The occurrence of intermediate and evolved lavas is restricted to the post-shield stage, with one exception (Eiao). Although these lavas are usually associated with alkali basaltic or basanitic magmas, several post-shield volcanoes are tholeiitic (Hiva Oa, Tahuata, Fatu Hiva) or include tholeiites (Nuku Hiva). In a given island, the trace element and isotopic compositions of shield and post-shield tholeiites overlap although both display large variations (Chauvel et al., 2012).

These features are inconsistent with former models (Duncan et al., 1986; Woodhead, 1992; Desonie et al., 1993; Castillo et al., 2007) that postulated that the Marquesas followed a "Hawaiian-type" evolution. They are consistent with the hypothesis of an extremely heterogeneous character of the Marquesas plume. The "weak" character of this plume led to low degrees of partial melting, which in turn resulted in the preservation in the basaltic magmas of geochemical features inherited from such small-size source heterogeneities.

\section{Acknowledgements}

This study has been funded by CNRS (INSU and UMR 8212, 6538, 5275, 6518), BRGM and CEADASE-DSM. We thank two anonymous reviewers for their very constructive comments that helped us to improve the overall content of the manuscript. We also thank Mayors Guy Rauzy and Etienne Tehaamoana (Hiva Oa), Henri Tuieinui (Fatu Hiva) and Félix Barsinas (Tahuata) who provided logistic support during

617 fieldwork. We are very grateful to Andy Teiki Richmond and the team of the Service du Développement 618 Rural of Atuona-Hiva Oa for their considerable help in the field, especially during coastal sampling and work 
in densely forested areas. Joseph Cotten's contribution to analytical work is greatly appreciated. Jean François Tannau and Vincent Scao provided helpful technical assistance. This is LSCE contribution N5115.

\section{References}

Blais, S., Legendre, C., Maury, R.C., Guille, G., Guillou, H., Rossi, P., Chauvel, C., 2008.

Notice explicative, carte géologique de France, feuille de Ua Huka, Polynésie française, 102 pp, scale 1: 50,000 , Bureau de Recherches Géologiques et Minières, Orléans, France.

Brousse, R., Barsczus, H.G., Bellon, H., Cantagrel, J.M., Diraison, C., Guillou, H., Léotot, C., 1990. Les Marquises (Polynésie française): volcanologie, géochronologie, discussion d'un modèle de point chaud [The Marquesas alignment (French Polynesia) - Volcanology, geochronology, a hotspot model]. Bulletin de la Société géologique de France 6, 933-949.

Cadio, C., Panet, I., Davaille, A., Diament, M., Métivier, L., de Viron, O., 2011. Pacific geoid anomalies revisited in light of thermochemical oscillating domes in the lower mantle. Earth Planetary Science Letters 306, 123-135.

Caress, D.V., McNutt, M.K., Detrick, R.S., Mutter, J.C., 1995. Seismic imaging of hotspot related crustal underplating beneath the Marquesas Islands. Nature 373, 600-603.

Caroff, M., Maury, R.C., Vidal, P., Guille, G., Dupuy, C., Cotten, J., Guillou, H., Gillot, P.Y., 1995. Rapid temporal changes in ocean island basalt composition - evidence from an $800 \mathrm{~m}$ deep drill hole in Eiao shield (Marquesas). Journal of Petrology 36, 1333-1365.

Caroff, M., Guillou, H., Lamiaux, M.I., Maury, R.C., Guille, G., Cotten, J., 1999.

Assimilation of ocean crust by hawaiitic and mugearitic magmas: an example from Eiao (Marquesas). Lithos 46, 235-258.

Carracedo, J.C., Day, S., Guillou, H., Badiola, E.R., Canas, J.A., Pérez Torrado, F.J., 1998. Hotspot volcanism close to a passive continental margin: The Canary Islands. Geological Magazine 135, 591-604.

Castillo, P.R., Scarsi, P., Craig, H., 2007. He, Sr, Nd and Pb isotopic constraints on the origin of the Marquesas and other linear volcanic chains. Chemical Geology 240, 205-221.

Chauvel, C., Maury, R.C., Blais, S., Lewin, E., Guillou, H., Guille, G., Rossi, P., Gutscher, M.-A., 2012. The size of plume heterogeneities constrained by Marquesas isotopic stripes. Geochemistry Geophysics Geosystems 13(1), Q07005, doi: 10.129/2012GC004123.

Chubb, L.J., 1930. The geology of the Marquesas islands. Bernice P. Bishop Museum Bulletin, 68, 1-71.

Clague, D.A., 1987. Hawaiian xenolith populations, magma supply rates, and development of magma chambers. Bulletin of Volcanology 49, 577-587.

Clague, D.A., Dalrymple, G.B., 1987. The Hawaiian-Emperor volcanic chain. Part 1. Geological evolution. United States Geological Survey Professional Paper 1350, 5-54.

Cotten, J., Le Dez, A., Bau, M., Caroff, M., Maury, R.C., Dulski, P., Fourcade, S., Bohn, M., Brousse, R., 1995. Origin of anomalous rare-earth element and yttrium enrichments in subaerially exposed basalts: Evidence form French Polynesia. Chemical Geology 119, 115-138.

Courtillot, V., Davaille, A., Besse, J., Stock, J., 2003. Three distinct types of hotspots in the Earth's mantle. Earth and Planetary Science Letters 205, 295-308.

Crough, S.T., Jarrard, R.D., 1981. The Marquesas-line swell. Journal of Geophysical Research 86, 17631771.

Dasgupta, R., Jackson, M.G., Lee, C.T.A., 2010. Major element chemistry of ocean island 
basalts - Conditions of mantle melting and heterogeneity of mantle source. Earth and Planetary Science Letters 289, 377-392.

Davaille, A., Girard, F., Le Bars, M., 2002. How to anchor hotspots in a convecting mantle ? Earth and Planetary Science Letters 203, 621-634.

Davis, F.A., Hirschmann, M.M., Humayun, M., 2011. The composition of the incipient partial melt of garnet peridotite at $3 \mathrm{GPa}$ and the origin of OIB. Earth and Planetary Science Letters 308, 380-390.

Day, J.M.D., Pearson, D.G., Macpherson, C.G., Lowry, D., Carracedo, J.C., 2009.

Pyroxenite-rich mantle formed by recycled oceanic lithosphere: Oxygen-osmium isotope evidence from Canary Island lavas. Geology 37, 555-558.

Desonie, D.L., Duncan, R.A., Natland, J.H., 1993. Temporal and geochemical variability of volcanic products of the Marquesas hotspot. Journal of Geophysical Research 98, 17649-17665.

Devey, C.W., Haase, K.M., 2003. The sources for hotspot volcanism in the South Pacific Ocean, in: R. Hékinian, P.S., J.L. Cheminée (Ed.), Oceanic hotspots: intraplate submarine magmatism and tectonism. Springer Verlag, Berlin, pp. 253-284.

Duncan, R.A., 1975. Linear volcanism in French Polynesia. Unpublished PhD Thesis, Australian National University.

Duncan, R.A., McDougall, I., 1974. Migration of volcanism with time in the Marquesas Islands, French Polynesia. Earth and Planetary Science Letters 21, 414-420.

Duncan, R.A., McCulloch, M.T., Barczus, H.G., Nelson, D.R., 1986. Plume versus lithospheric sources for the melts at Ua Pou, Marquesas Island. Nature 303, 142-146.

Farnetani, C.G., Hofmann, A.W., 2010. Dynamics and internal structure of the Hawaiian plume. Earth and Planetary Science Letters 295, 231-240.

Fekiacova, Z., Abouchami, W., Galer, S.J.G., Garcia, M.O., Hofmann, A.W., 2007. Origin and temporal evolution of Ko'olau Volcano, Hawai'i: Inferences from isotope data on the Ko'olau Scientific Drilling Project (KSDP), the Honolulu Volcanics and ODP Site 843. Earth and Planetary Science Letters 261, 65-83.

Filmer, P.E., McNutt, M.K., Wolfe, C.J., 1993. Elastic thickness of the lithosphere in the Marquesas and Society Islands. Journal of Geophysical Research 98, 1956519577.

Frey, F.A., Wise, W.S., Garcia, M.O.,West, H., Kwon, S.-T., Kennedy, A., 1990. Evolution of Mauna Kea volcano, Hawaii: petrologic and geochemical constraints on postshield volcanism. Journal of Geophysical Research 95, 1271-1300.

Frey, F.A., Huang, J., Blichert-Toft, J., Regelous, M., Boyet, M., 2005. Origin of depleted components in basalt related to the Hawaiian hot spot: Evidence from isotopic and incompatible element ratios. Geochemistry Geophysics Geosystems 6, Q02107, doi:10.129/2004GC000757.

Garcia, M.O., Swinnard, L., Weis, D., Greene, A.R., Tagami, T., Sano, H., Gandy, C.E., 2010. Petrology, geochemistry and geochronology of Kaua'i lavas over 4.5 Myr: implications for the origin of rejuvenated volcanism and the evolution of the Hawaiian plume. Journal of Petrology 51, 1507-1540.

Gibson, S.A., Geist, D.G., Day, J.A., Dale, C.W., 2012. Short wavelength heterogeneity in the Galápagos plume: evidence from compositionally diverse basalts on Isla Santiago.. Geochemistry Geophysics Geosystems 13(1), Q09007, doi: 10.129/2012GC004244.

Guille, G., Legendre, C., Maury, R.C., Caroff, M., Munschy, M., Blais, S., Chauvel, C., 
Cotten, J., Guillou, H., 2002. Les Marquises (Polynésie française): un archipel intraocéanique

Guille, G., Legendre, C., Maury, R.C., Guillou, H., Rossi, P., Blais, S., 2010. Notice explicative, carte géologique de France, feuille de Ua Pou, Polynésie française, 133 pp, scale 1: 30,000, Bureau de Recherches Géologiques et Minières, Orléans, France, in press.

Guille, G., Maury, R.C., (coordinators), 2013. Carte géologique de la feuille Groupe Sud de l'archipel des Iles Marquises (Hiva Oa - Tahuata - Motane et Fatu Hiva), Polynésie française, scale 1: 100,000, Bureau de Recherches Géologiques et Minières, Orléans, France, in press.

Guillou, H, Maury, R.C., Blais, S., Cotten, J., Legendre, C., Guille, G., Caroff, M., 2005. Age progression along the Society hot spot chain (French Polynesia) based on new unspiked K-Ar ages. Bulletin de la Société géologique Française 176, 135-150.

Guillou, H., Nomade, S., Carracedo, J.C., Kissel, C., Laj, C., Perez Torrado, F.J., Wandres, C., 2011. Effectiveness of combined unspiked $\mathrm{K}-\mathrm{Ar}$ and $40 \mathrm{Ar} / 39 \mathrm{Ar}$ dating methods in the $14 \mathrm{C}$ age range. Quaternary Geochronology 6, 530-538.

Gutscher, M.A., Olivet, J.L., Aslanian, D., Eissen, J.P., Maury, R., 1999. The "lost Inca Plateau": cause of flat subduction beneath Peru? Earth and Planetary Science Letters 171, 335-341.

Hanano, D., Weis, D., Scoates, J.S., Aciego, S., DePaolo, D.J., 2010. Horizontal and vertical zoning of heterogeneities in the Hawaiian mantle plume from the geochemistry of consecutive postshield volcano pairs: Kohala-Mahukona and Mauna Kea-Hualalai. Geochemistry Geophysics Geosystems 11, Q01004, doi:10.129/2009GC002782.

Herzberg, C., 2011. Identification of Source Lithology in the Hawaiian and Canary Islands: Implications for Origins. Journal of Petrology 52, 113-146.

Jackson, M.G., Dasgupta, R., 2008. Compositions of HIMU, EM1, and EM2 from global trends between radiogenic isotopes and major elements in ocean island basalts. Earth Planetary Science Letters 276, 175-186.

Jordahl, K.A., McNutt, M.K., Webb, H.F., Kruse, S.E., Kuykendall, M.G., 1995. Why there are no earthquakes on the Marquesas Fracture Zone. Journal of Geophysical Research 100, 24431-24447.

Konter, J.G., Jackson, M.G., 2012. Large volumes of rejuvenated volcanism in Samoa: evidence supporting a tectonic influence on late-stage volcanism. Geochemistry Geophysics Geosystems 13, Q0AM04, doi:10.129/2011GC003974.

Lacroix, A., 1928. Nouvelles observations sur les laves des îles Marquises et de l'île Tubuai (Polynésie australe). Comptes Rendus de l'Académie des Sciences Paris 187, 365-369.

Laughlin, A.W., Poths, J., Healey, H.A., Reneau, S., Woldegabriel, G., 1994. Dating of Quaternary basalts using the cosmogenic He-3 and C-14 methods with implications for excess Ar-40. Geology 22, $135-138$.

Le Bas, M.J., Le Maitre, R.W., Streckeisen, A., Zanettin, B., 1986. A chemical classification of volcanic rocks based on the total-alkali-silica diagram. Journal of Petrology 27, 745-750.

Legendre, C., Maury, R.C., Caroff, M., Guillou, H., Cotten, J., Chauvel, C., Bollinger, C., Hémond, C., Guille, G., Blais, S., Rossi, P., Savanier, D., 2005a. Origin of exceptionally abundant phonolites on Ua Pou island (Marquesas, french Polynesia): partial melting of basanites followed by crustal contamination. Journal of Petrology 46, 1925-1962.

Legendre, C., Maury, R.C., Savanier, D., Cotten, J., Chauvel, C., Hémond, C., Bollinger, C., Guille, G., Blais, S., Rossi, P., 2005b. The origin of intermediate and evolved lavas in the Marquesas archipelago: an example from Nuku Hiva island (French Polynesia). Journal of Volcanology and Geothermal Research 143, 293-317. 
Legendre, C., Maury, R.C., Blais, S., Guillou, H., Cotten, J., 2006. Atypical hotspot chains: evidence for a secondary melting zone below the Marquesas (French Polynesia). Terra Nova $18,210-216$.

Macdonald, G.A., Katsura, T., 1964. Chemical composition of Hawaiian lavas. Journal of Petrology 5, 82133.

Marske, J.P., Pietruszka, A.J., Weis, D., Garcia, M.O., Rhodes, J.M., 2007. Rapid passage of a small-scale mantle heterogeneity though the melting regions of Kilauea and Mauna Loa volcanoes. Earth and Planetary Science Letters 259, 34-50.

Maury, R.C., Guille, G., Legendre, C., Savanier, D., Guillou, H., Rossi, P., Blais, S., 2006. Notice explicative, carte géologique de France, feuille de Nuku Hiva, Polynésie française. 116 pp, scale 1: 50,000, Bureau de Recherches Géologiques et Minières, Orléans, France.

Maury, R.C., Legendre, C., Guille, G., Demange, J., Caroff, M., 2009.Notice explicative, carte géologique de France, feuille d'Eiao, Polynésie française, 89 pp, scale 1: 25,000, Bureau de Recherches Géologiques et Minières, Orléans, France.

Maury, R.C., Guille, G., Guillou, H., Rossi, P., Legendre, C., Chauvel, C., Blais, S., Ottino, P., Meyer, J.-Y., Deroussi, S., Tegyey, M., Cabioch, G., 2013. Notice explicative, carte géologique de France, feuille Groupe Sud de l'archipel des lles Marquises (Hiva Oa - Tahuata - Motane et Fatu Hiva), Polynésie française, XX pp, scale 1: 100,000, Bureau de Recherches Géologiques et Minières, Orléans, France, in press.

McDougall, I., Duncan, R.A., 1980. Libnear volcanic chains: recording plate motions? Tectonophysics 63, 275-295.

McNutt, M., Bonneville, A., 2000. A shallow, chemical origin for the Marquesas Swell. Geochemistry Geophysics Geosystems 1, 1999GC000028.

McNutt, M., Fischer, K., Kruse, S., Natland, J., 1989. The origin of the Marquesas fracture zone ridge and its implications for the nature of hot spots. Earth and Planetary Science Letters 91, 381-393.

Merle, O., Barde-Cabusson, S., Maury, R.C., Legendre, C., Guille, G., Blais, S., 2006. Volcano core collapse triggered by regional faulting. Journal of Volcanology and Geothermal Research 158, 269-280.

Paul, D., White, W.M., Blichert-Toft, J, 2005. Geochemistry of Mauritius and the origin of rejuvenescent volcanism on oceanic island volcanoes. Geochemistry Geophysics Geosystems 6, Q06007, doi: 10.129/2004GC000883.

Pautot, G., Dupont, J., 1974. La zone de fracture des Marquises. Comptes Rendus de l'Académie des Sciences Paris 279, 1519-1523.

Ribe N.M, Christensen U.R., 1999. The dynamical origin of Hawaiian volcanism. Earth and Planetary Science Letters 171, 517-531.

Shafer, J.T., Neal, C.R., Regelous, M. 2005. Petrogenesis of Hawaiian postshield lavas: evidence from Nintoku Seamount, Emperor Seamount Chain. Geochemistry Geophysics Geosystems 6, Q05L09, doi: 10.129/2004GC000875.

Smith, W.H.F., Sandwell, D.T., 1997. Global sea floor topography from satellite altimetry and ship depth soundings. Science 277, 1956-1962.

Sobolev, A.V., Hofmann, A.W., Sobolev, S.V., Nikogosian, I.K., 2005. An olivine-free mantle source of Hawaiian shield basalts. Nature 434, 590-597.

Sobolev, A.V., Hofmann, A.W., Kuzmin, D.V.,Yaxley, G.M., Arndt, N.T., Chung, S.-L., Danyushevsky, L.V., Elliott, T., Frey, F.A., Garcia, M.O., Gurenko, A.A., Kamenetsky, V.S., Kerr, A.C., Krivolutskaya, N.A., 
Matvienkov, V.V., Nikogosian, I.K., Rocholl, A., Sigurdsson, I.A., Sushchevskaya, N.M., Teklay, M., 2007. The Amount of Recycled Crust in Sources of Mantle-Derived Melts. Science 316, 412-417.

Stearns, H.T., 1966. Geology of the State of Hawaii: Palo Alto. Pacific Books, 266 p.

Steiger, R.H., Jäger, E., 1977. Subcommission on geochronology: convention on the use of

862

863

864

865

866

867

868

869

870 decay constants in geo-and cosmochronology. Earth and Planetary Science Letters 36, 359-362.

Vidal, P., Chauvel, C., Brousse, R., 1984. Large mantle heterogeneity beneath French Polynesia. Nature 307, 536-538.

Vidal, P., Dupuy, C., Barsczus, H.G., Chauvel, C., 1987. Hétérogénéités du manteau et origine des basaltes des Marquises (Polynésie). Bulletin de la Société géologique de France 4, 633-642.

Westaway, R., Guillou, H., Yurtmen, S., Demir, T., Scaillet, S., Rowbotham, G., 2005. Constraints on the timing and regional conditions at the start of the present phase of crustal extension in western Turkey, from observations in and around the Denizli region. Geodinamica Acta. 18/3-4, 209-238.

White, W.M., 2010. Oceanic Island Basalts and Mantle Plumes: The Geochemical Perspective, in: Jeanloz, R., Freeman, K.H. (Eds.), Annual Review of Earth and Planetary Sciences, Vol 38. Annual Reviews, Palo Alto, pp. 133-160.

Woodhead, J.D., 1992. Temporal geochemical evolution in oceanic intra-plate volcanics: a case study from the Marquesas (French Polynesia) and comparison with other hotspots. 
Fig. 1. Location map of Marquesas Islands. The bathymetry comes from the global altimetry data set of Smith and Sandwell (1997). The main trend of the Marquesas chain is $\mathrm{N} 40^{\circ} \mathrm{W}$. Current Pacific plate motion is $10.5 \mathrm{~cm} / \mathrm{yr}$ at $\mathrm{N} 65^{\circ} \mathrm{W}$, corresponding to the line shown in white. The names of the southern islands are in large print. MFZ: Marquesas Fracture Zone.

Fig. 2. Age versus distance plot for the Marquesas. The distances to the MFZ Ridge (MFZR) along $\mathrm{N} 65^{\circ} \mathrm{W}$ trend corresponding to the $10.5 \mathrm{~cm} / \mathrm{yr}$ motion of the Pacific plate are from Chauvel et al. (2012). The dashed line starts from the unexplored chain of seamounts located $50 \mathrm{~km}$ NW of the MFZR. Shield ages are denoted by open symbols, post-shield ages by filled symbols and rejuvenated ages by grey symbols. Sources of unspiked ${ }^{40} \mathrm{~K}-{ }^{40} \mathrm{Ar}$ ages on groundmass: Tables 1 and 3 for southern islands; Caroff et al. (1995) and Maury et al. (2009) for Eiao; Maury et al. (2006) for Nuku Hiva; Legendre et al. (2006) and Blais et al. (2008) for Ua Huka; Legendre et al. (2005a) and Guille et al. (2010) for Ua Pou.

Fig. 3. Total-Alkali-Silica (TAS) diagram (Le Bas et al., 1986) for the dated Marquesas lavas. The dashed line separating the fields of tholeiitic (Thol.) and alkali (Alk.) basalts is from Macdonald and Katsura 902 (1964). Shield ages are denoted by open symbols, post-shield ages by filled symbols and rejuvenated ages by grey symbols. Sources of major and trace element analyses: Tables 2 and 4 for southern islands; Caroff et al. (1995) and Maury et al. (2009) for Eiao; Maury et al. (2006) for Nuku Hiva; Legendre et al. (2006) and Blais et al. (2008) for Ua Huka; Legendre et al. (2005a) and Guille et al. (2010) for Ua Pou.

Fig. 4. Sketches of the Marquesas volcanic successions, showing caldera collapse events (red dashed lines) and simplified distributions of tholeiitic basalts, alkali basalts and basanites, and felsic lavas (trachytes and phonolites). Intermediate lavas have been omitted for clarity. Vertical scales are arbitrary. Abbreviated volcano names: Ha: Hane; Hi: Hikitau; Hk: Hakahau; Hn: Hanatetena; Om: Omoa; Oo: Ootua; Pu: Puamau; Ta: Taaoa; Te: Temetiu; Th: Taiohae; Tk: Tekao; To: Touaouoho; Va: Vaitahu. In Ua Huka, a temporal gap separates the end of building of the Hane volcano from the rejuvenated volcanic phase which emplaced the Teepoepo (1.15-0.96 Ma) and Tahoatikikau (0.82-0.76 Ma) basanitic cones. In Tahuata, the horizontal line below the red dashed line separates the upper from the lower tholeiitic flows of Vaitahu shield.

Fig. 5. Geological sketch maps of the southern Marquesas islands, simplified from Guille and Maury (2013) and Maury et al. (2013). The locations of the dated samples are shown by small red crosses (corresponding ages in Ma from Tables 1 and 3). Most flow dips range from 8 to $12^{\circ}$. See text for explanations.

Fig. 6. Plot of unspiked ${ }^{40} \mathrm{~K}-{ }^{40} \mathrm{Ar}$ ages against $\mathrm{SiO}_{2}$ for dated samples. Symbols and sources of data as in Figs. 2 and 3.

Fig. 7. Plot of $L a / Y b$ against $L a(p p m)$ for dated samples. Symbols and sources of data as in Fig. 3. 
Fig. $8 .{ }^{87} \mathrm{Sr} /{ }^{86} \mathrm{Sr}$ versus ${ }^{143} \mathrm{Nd} /{ }^{144} \mathrm{Nd}$ diagram showing the differences between tholeiitic basalts and alkali basalts/basanites from Marquesas islands. Data from the GEOROC database and Chauvel et al. (2012). The Fatu Hiva sample plotting away from the main trend $\left(l o w^{143} \mathrm{Nd} /{ }^{144} \mathrm{Nd}\right)$ is from Woodhead $(1992)$.

\section{Table captions}

Table 1. Unspiked ${ }^{40} \mathrm{~K}-{ }^{40} \mathrm{Ar}$ ages measured on groundmass for Hiva Oa lavas. See text for analytical methods and Fig. 4 for sample locations. SH: shield; PS: post-shield. Mugear.: mugearite; benmor.: benmoreite. *: ages already given in Chauvel et al. (2012) but without details.

Table 2. Major and trace element ICP-AES analyses of dated lavas from Hiva Oa. Major element oxides in wt\%, trace elements in ppm. $\mathrm{Fe}_{2} \mathrm{O}_{3}{ }^{*}$ : total iron as $\mathrm{Fe}_{2} \mathrm{O}_{3}$. See text for analytical methods, Table 1 for ages and Fig. 4 for sample locations. Samples are ranked by order of decreasing ages. SH: shield; PS: postshield. Thol: tholeiite; haw: hawaiite; mug: mugearite; ben: benmoreite; tra: trachyte. The rare earth element and $\mathrm{Y}$ concentrations of sample HV54 have been modified by supergene alteration involving crystallization of rhabdophane (Cotten et al., 1995), and therefore this sample has not been plotted in Fig. 6. *: Major element analyses given in Chauvel et al. (2012) together with ICP-MS trace element analyses.

Table 3. Unspiked ${ }^{40} \mathrm{~K}-{ }^{40} \mathrm{Ar}$ ages measured on groundmass for Motane, Tahuata and Fatu Hiva lavas. See text for analytical methods and Fig. 4 for sample locations. SH: shield; PS: post-shield. Alk. bas.: alkali basalt. *: ages already given in Chauvel et al. (2012) but without details.

Table 4. Major and trace element ICP-AES analyses of dated lavas from Motane, Tahuata and Fatu Hiva. Major element oxides in wt\%, trace elements in ppm. $\mathrm{Fe}_{2} \mathrm{O}_{3}{ }^{*}$ : total iron as $\mathrm{Fe}_{2} \mathrm{O}_{3}$. See text for analytical methods, Table 3 for ages and Fig. 4 for sample locations. For each island, samples are ranked by order of decreasing ages. SH: shield; PS: post-shield. Thol: tholeiite; alb: alkali basalt; bas: basanite; haw: hawaiite; teph: tephriphonolite; tra: trachyte. *: Major element analyses given in Chauvel et al. (2012) together with ICP-MS trace element analyses. 


\section{Volcanic successions in Marquesas eruptive centers: A departure} from the Hawaiian model

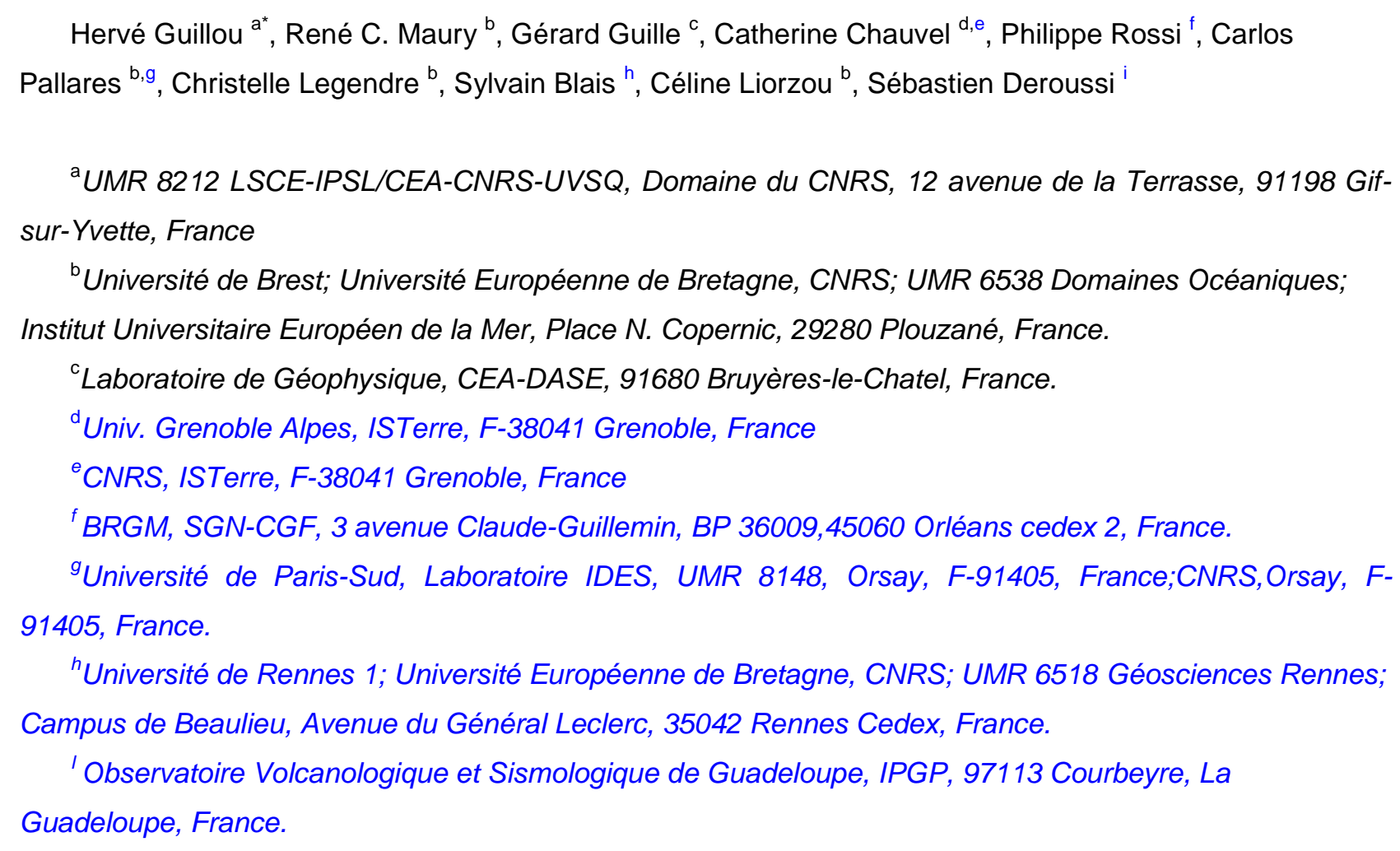

${ }^{a}$ UMR 8212 LSCE-IPSL/CEA-CNRS-UVSQ, Domaine du CNRS, 12 avenue de la Terrasse, 91198 Gifsur-Yvette, France

' Université de Brest; Université Européenne de Bretagne, CNRS; UMR 6538 Domaines Océaniques; Institut Universitaire Européen de la Mer, Place N. Copernic, 29280 Plouzané, France.

${ }^{\mathrm{C}}$ Laboratoire de Géophysique, CEA-DASE, 91680 Bruyères-le-Chatel, France.

'Univ. Grenoble Alpes, ISTerre, F-38041 Grenoble, France

${ }^{e}$ CNRS, ISTerre, F-38041 Grenoble, France

${ }^{\dagger}$ BRGM, SGN-CGF, 3 avenue Claude-Guillemin, BP 36009,45060 Orléans cedex 2, France.

${ }^{9}$ Université de Paris-Sud, Laboratoire IDES, UMR 8148, Orsay, F-91405, France;CNRS,Orsay, F91405, France.

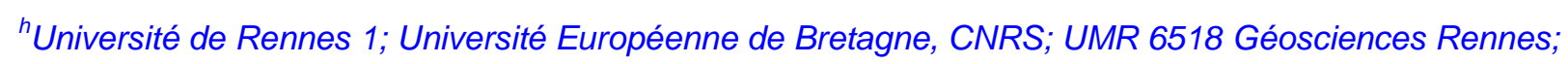
Campus de Beaulieu, Avenue du Général Leclerc, 35042 Rennes Cedex, France.

'Observatoire Volcanologique et Sismologique de Guadeloupe, IPGP, 97113 Courbeyre, La Guadeloupe, France.

* Corresponding author. Tel.: + 33169823556; fax: +33169823568

E-mail address: herve.guillou@lsce.ispl.fr

\section{Abstract}

The temporal and geochemical evolution of Marquesas hotspot volcanoes have often been interpreted with reference to the Hawaiian model, where a tholeiitic shield-building stage is followed by an alkali basaltic post-shield stage, followed after a 0.4 to $2.5 \mathrm{Myr}$ long quiescence period, by a rejuvenated basanitic/nephelinitic stage. Here we discuss geochemical data on 110 Marquesas lavas also dated using the unspiked ${ }^{40} \mathrm{~K}-{ }^{40} \mathrm{Ar}$ method on separated groundmass (including 45 new ages measured on the southern islands of Hiva Oa, Motane, Tahuata and Fatu Hiva). Sample locations were positioned on detailed geological maps to determine their shield or post-shield position with respect to the caldera collapse event(s), without taking into account their geochemical features. A rather regular decrease of the ages towards SE, consistent with the Pacific plate motion, is observed from Eiao (5.52 Ma) to Fatu Hiva (1.11 $\mathrm{Ma}$ ), and rejuvenated basanitic volcanism occurs only in Ua Huka (1.15-0.76 Ma). The occurrence of intermediate and evolved lavas is restricted to the post-caldera stage, with the exception of Eiao island. However, many other features of the Marquesas chain are rather atypical with respect to those of Hawaii. 
Although Marquesas shields are tholeiitic, several of them (Eiao, Tahuata) contain interbedded alkali basaltic and basanitic flows. Moreover, post-shield volcanoes are either alkali basalts (Ua Huka), tholeiites (Hiva Oa, Tahuata, Fatu Hiva) or both (Nuku Hiva). This feature is consistent with the temporal continuity of the two stages and the usually short length of the post-shield period $(<0.2 \mathrm{Myr})$. In a given island, the trace element and isotopic compositions of shield and post-shield lavas overlap, although both display large variations. The sources of alkali basalts and basanites are more enriched than those of the contemporaneous tholeiites. These specific features support the hypothesis of an extremely heterogeneous Marquesas plume. The "weak" character of this plume led to low partial melting degrees, which in turn resulted in the preservation in the basaltic magmas of geochemical features inherited from small-size source heterogeneities.

Keywords: Shield, Post-shield, Tholeiite, Alkali basalt, Trachyte, ${ }^{40} \mathrm{~K}-{ }^{40} \mathrm{Ar}$ age, Hotspot, Marquesas.

(1)

5

\section{Introduction}

The temporal evolution of plume-related oceanic intraplate volcanoes has often been investigated with reference to the classical Hawaiian model, in which four successive growth stages are distinguished (Clague and Dalrymple, 1987; Clague, 1987; Hanano et al., 2010): (1) a small volume (ca. 3\%) alkalic pre-shield stage, emplacing mostly submarine alkali basalts and basanites; (2) the main shield-building stage, during which the majority (95-98\%) of the volcano is rapidly constructed, culminating in subaerial flows of tholeiitic basalts; (3) the alkalic post-shield phase, during which small volumes (1-2\%) of alkali basalts and related intermediate/evolved lavas (hawaiites, mugearites, benmoreites and trachytes) are erupted; and finally (4) the alkalic rejuvenated stage, during which very small volumes $(<<1 \%)$ of basanites, alkali basalts and nephelinites are emplaced after a quiescence period. In the Hawaiian chain, shield tholeiitic basalts are less enriched in incompatible elements and derive from larger melting rates than the post-shield and rejuvenated alkalic lavas; in addition, the mantle sources of the latter are isotopically depleted with respect to those of the tholeiites (lower ${ }^{87} \mathrm{Sr} /{ }^{86} \mathrm{Sr}$ and ${ }^{206} \mathrm{~Pb} /{ }^{204} \mathrm{~Pb}$, higher ${ }^{143} \mathrm{Nd} /{ }^{144} \mathrm{Nd}$ : Frey et al., 1990, 2005; Shafer et al., 2005; Fekiacova et al., 2007; Garcia et al., 2010; Hanano et al., 2010).

For Hawaiian volcanoes, the main criterion used for the distinction between the shield-building and postshield stages is the change from tholeiites to alkali basalts. Indeed, Clague and Dalrymple (1987) stated (their page 7) that "the shield stage usually includes caldera collapse and eruptions of caldera-filling tholeiitic basalt. During the next stage, the alkalic postshield stage, alkalic basalt also may fill the caldera and form a thin cap of alkalic basalt and associated differentiated lava that covers the main shield". They also mentioned (their page 8) that "we have omitted the main caldera-collapse stage of Stearns (1966) from the eruption sequence because it can occur either during the shield stage or near the beginning of the alkalic postshield stage. The lava erupted may therefore be tholeiitic or alkali basalt, or of both types". 
Large major, trace element and isotopic variations in Marquesas lavas have been known for decades (Vidal et al., 1984, 1987; Duncan et al., 1986). They have been interpreted with reference to the shield/postshield Hawaiian model by several authors (Duncan et al., 1986; Woodhead, 1992; Desonie et al., 1993; Castillo et al., 2007). However, most of these works were based on the pioneer (and hence limited) sampling of Marquesas Islands made during the 1970's by R.A. Duncan (Duncan and McDougall, 1974; Duncan,

84 1975; McDougall and Duncan, 1980) and R. Brousse (Vidal et al., 1984; Brousse et al., 1990). No geological maps of the islands were available at that time, and therefore the distinction between shield and post-shield lavas was usually made using geochemical criteria. For instance, the observation that the oldest lavas from Nuku Hiva, Ua Pou and Hiva Oa are tholeiitic basalts (Duncan, 1975; Duncan et al., 1986) led Woodhead (1992) to classify hypersthene-normative Marquesas lavas as shield-related and alkali basalts/basanites as post-shield. Later, Castillo et al. (2007) studied samples collected by $\mathrm{H}$. Craig, and used ${ }^{87} \mathrm{Sr} /{ }^{86} \mathrm{Sr}(>0.7041)$ and ${ }^{143} \mathrm{Nd} /{ }^{144} \mathrm{Nd}(<0.51285)$ ratios to characterize post-shield lavas, based on the isotopic data of Woodhead (1992) obtained on R.A. Duncan's samples.

A mapping program of the Marquesas archipelago (2001-2009) led us to collect a number of new samples and draw detailed geological maps of the islands. The trace element and $\mathrm{Sr}, \mathrm{Nd}, \mathrm{Pb}$ and $\mathrm{Hf}$ isotopic features of these samples (Chauvel et al., 2012) point towards relationships between shield and post-shield lavas more complex than previously thought. Here, we use geological settings combined with unspiked ${ }^{40} \mathrm{~K}$ ${ }^{40} \mathrm{Ar}$ ages measured on groundmass and petrologic/geochemical features of this new sample set to demonstrate that the temporal evolution of the Marquesas volcanoes is rather different from that of Hawaiian volcanoes. We also discuss the constraints that they set on the corresponding plume/hotspot model.

\section{Geological setting and previous work}

\subsection{The Marquesas archipelago}

The ca. 350 km-long Marquesas archipelago, located in northern French Polynesia, includes eight main islands (Fig. 1) that cluster into a northern group (Eiao, Nuku Hiva, Ua Huka and Ua Pou) and a southern group (Hiva Oa, Tahuata, Motane, Fatu Hiva); few islets ("motu”), banks and seamounts also exist (Fig. 1). The age of the islands decreases towards the SE (Duncan and McDougall, 1974; Brousse et al., 1990) from 5.5 Ma in Eiao to 0.6-0.35 Ma on the DH12 seamount south of Fatu Hiva (Desonie et al., 1993). However, no active volcanoes are known at the southeastern edge of the chain. ${ }^{40} \mathrm{~K}-{ }^{40} \mathrm{Ar}$ ages younger than $1 \mathrm{Ma}$ have been obtained only on $\mathrm{DH} 12$ and on the Teepoepo (1.15-0.96 Ma) and Tahoatikikau (0.82-0.76 Ma) strombolian cones on Ua Huka (Legendre et al., 2006; Blais et al., 2008). These cones were emplaced after a 1.3 Myr quiescence period, and are considered as the only example of rejuvenated volcanism in the Marquesas (Legendre et al., 2006; Chauvel et al., 2012). Most authors believe that the Marquesas Fracture Zone (MFZ; Pautot and Dupont, 1974) overlies the present position of the hotspot activity (McNutt et al., 1989; Brousse et al., 1990; Guille et al., 2002). However, the MFZ is aseismic (Jordahl et al., 1995) and no young volcanic rock has been recovered from the adjacent Marquesas Fracture Zone Ridge (MFZR; Fig. 1). The seamount chain parallel to the MFZ ridge ca. $50 \mathrm{~km}$ to the north (Fig. 1) has not yet been dredged and it could possibly mark the present location of Marquesas hotspot activity. 
The Marquesas archipelago is atypical in many respects (Brousse et al., 1990; Guille et al., 2002; Devey and Haase, 2003). It lies on an anomalously shallow (less than 4,000 m deep) 53-49 Ma old oceanic crust generated at the axis of the Pacific-Farallon ridge (Crough and Jarrard, 1981), and its crustal thickness reaches 15-20 km below the central part of the chain (Filmer et al., 1993; Caress et al., 1995). This abnormally thick crust is attributed either to underplating of plume magmas below the Moho (Caress et al., 1995; McNutt and Bonneville, 2000) or to the construction of the archipelago over a small 50-45 Ma old oceanic plateau that formed near the axis of the Pacific-Farallon ridge (Gutscher et al., 1999). In addition, the N30-40 $\mathrm{W}$ direction of the archipelago is oblique to that of the current $\mathrm{N} 65^{\circ} \mathrm{W}$ motion of the Pacific plate (Fig. 1), but parallel to the spreading axis of the Pacific-Farallon ridge prior to the current orientation of accretion along the East Pacific Rise. This feature suggests that zones of weakness in the underlying Pacific-Farallon plate might have controlled the emplacement of the Marquesas magmas (Crough and Jarrard, 1981; McNutt et al., 1989). Age-distance to the MFZR plots using the main N30-40 $\mathrm{W}$ trend of the chain and all available ${ }^{40} \mathrm{~K}-{ }^{40} \mathrm{Ar}$ ages display considerable scatter (Brousse et al., 1990; Desonie et al., 1993; Guille et al., 2002). Similar plots using the N65 W trend give better fits (Legendre et al., 2006; Chauvel et al., 2012), especially when considering only unspiked ${ }^{40} \mathrm{~K}-{ }^{40} \mathrm{Ar}$ ages measured on separated groundmass (Fig. 2), which are more accurate and reliable than conventional ${ }^{40} \mathrm{~K}-{ }^{40} \mathrm{Ar}$ data on whole rocks. Recently, Chauvel et al. (2012) showed that the chain is made of two adjacent rows of islands with distinct $\mathrm{Sr}, \mathrm{Nd}, \mathrm{Pb}$ isotopic features, delineating two isotopic stripes. At any given ${ }^{143} \mathrm{Nd} /{ }^{144} \mathrm{Nd}$ value, the northeastern row (the "Ua Huka group") has systematically higher ${ }^{87} \mathrm{Sr} /{ }^{86} \mathrm{Sr}$ and lower ${ }^{206} \mathrm{~Pb} /{ }^{204} \mathrm{~Pb}$ ratios than the southwestern row (the "Fatu Hiva group"). These rows are thought to originate from the partial melting of two adjacent filaments contained in an elongated ascending plumelet or secondary plume, rooted in a larger dome located at the base of the upper mantle (Davaille et al., 2002; Courtillot et al., 2003; Cadio et al., 2011).

The common occurrence of nested volcanoes in the Marquesas was first reported by L.J. Chubb (1930). Half of the islands (Nuku Hiva, Ua Huka, Tahuata, Fatu Hiva) are made up of a large external (outer) shield volcano with a central caldera. A younger and smaller internal (inner) post-shield volcanic edifice has grown inside this caldera. Hiva Oa comprises three adjacent shields: the larger one is unconformably overlain by post-shield flows, which also filled up part of its caldera. Ua Pou is rather unusual, because this island lacks a well-exposed outer shield and is mostly made up of phonolitic flows interbedded with basanitic and tephritic flows (Fig. 3), and crosscut by huge phonolitic spines (Legendre et al., 2005a). The two smallest islands, Eiao and Motane, represent crescent-shaped remnants of the caldera wall and external upper slopes of much larger collapsed shield volcanoes (Brousse et al., 1990; Guille et al., 2002). Therefore, the shield-building or post-shield character of a given Marquesan sample with respect to caldera collapse events

151 (see Stearns, 1966, for the case of Hawaii) can be determined using only its geological position deduced 152 from field relationships and its ${ }^{40} \mathrm{~K}-{ }^{40} \mathrm{Ar}$ age, without making any assumption based on its petrologic and 153 geochemical features. We choose this approach because no well-defined temporal change from tholeiitic to 154 alkali volcanism is observed in most Marquesas volcanoes. In the present work, we use a coherent set of 155110 lava samples to investigate the temporal geochemical evolution of the Marquesas volcanoes, with 156 special attention to the respective features of shield-building, post-shield and rejuvenated (Ua Huka) stages 157 of volcanic activity. All samples were collected during the 2001-2009 mapping program, dated by the 
unspiked ${ }^{40} \mathrm{~K}-{ }^{40} \mathrm{Ar}$ method on groundmass at Gif-sur-Yvette laboratory and analyzed for major and trace elements by ICP-AES at Plouzané (Brest) laboratory.

\subsection{Summary of the geological and geochemical features of the northern group islands}

The four islands from the northern group (Eiao, Nuku Hiva, Ua Huka and Ua Pou) were studied

163

164 previously using the same methods (Caroff et al., 1995, 1999; Legendre et al., 2005a, 2005b, 2006; Maury et al., 2006, 2009; Blais et al., 2008; Guille et al., 2010). Their volcanic successions are shown schematically in Figure 4. Below we provide a short description of their main features.

\subsubsection{Eiao}

Eiao (Maury et al., 2009) is the northernmost (Fig. 1) and largest $\left(44 \mathrm{~km}^{2}\right)$ uninhabited island in French Polynesia. It corresponds to the northwestern crescent-shaped remains of the caldera wall and of the external upper slopes of a $20 \mathrm{~km}$ large collapsed volcano. Its coastal cliffs expose a ca $400 \mathrm{~m}$ thick pile of tholeiitic basaltic flows interbedded with less common alkali basalts and crosscut by a dense network of radial dykes. Three deep core drillings have sampled the upper 1,200 $\mathrm{m}$ thick sequence of the Eiao shield, down to $-700 \mathrm{~m}$ below sea level (Caroff et al., 1995, 1999). The base of this sequence, dated at 5.52-5.48 Ma (Fig. 2), is made up of quartz-normative tholeiitic flows overlain by olivine tholeiitic flows (Fig. 3). These are in turn overlain by a ca $250 \mathrm{~m}$ thick sequence of hawaiites and mugearites, with a single intercalated trachytic flow 5.44 Ma old (Fig. 4). The middle (dated at 5.36-5.25 Ma) and upper (4.98-4.95 Ma) parts of the drilled pile are mostly made up of olivine tholeiites intercalated with picrobasaltic and alkali basaltic flows (Caroff et al., 1995, 1999; Maury et al., 2009). The old quartz tholeiites are less enriched in incompatible elements than the overlying olivine tholeiites and alkali basalts, and their $\mathrm{Sr}, \mathrm{Nd}, \mathrm{Pb}$ isotopic composition tends towards a HIMU end-member. Hawaiites and mugearites result from open-system fractional crystallization of the latter basaltic magmas, coupled with variable extents of assimilation of materials from the underlying oceanic crust (Caroff et al., 1999).

\subsubsection{Nuku Hiva}

Nuku Hiva (Legendre et al., 2005b; Maury et al., 2006) is the largest island of the archipelago $\left(339 \mathrm{~km}^{2}\right)$. It has a semicircular shape, and its northern, western and eastern parts correspond to the northern half of a huge shield, the Tekao volcano (Fig. 4). It is exclusively made up of olivine tholeiites (Fig. 2) derived from a mantle source containing a depleted MORB mantle (DMM) component. Its upper flows were emplaced between 4.01 and $3.83 \mathrm{Ma}$ according to unspiked ${ }^{40} \mathrm{~K}-{ }^{40} \mathrm{Ar}$ data (Fig. 3), although altered flows from the lower part of the exposed pile yielded ${ }^{40} \mathrm{Ar}^{39} \mathrm{Ar}$ ages ranging from 4.52 to $4.08 \mathrm{Ma}$ (Maury et al., 2006). Between 4.00 and $3.62 \mathrm{Ma}$ (unspiked ${ }^{40} \mathrm{~K}-{ }^{40} \mathrm{Ar}$ data), the Taiohae inner (post-shield) volcano grew inside the caldera of the Tekao shield, after the southern part of the latter collapsed along a $N 75^{\circ} \mathrm{E}$ trending normal fault parallel to the MFZ. This collapse event at ca $4.0 \mathrm{Ma}$ (Fig. 4) has been attributed to the lateral spreading of a weak hydrothermal zone located in the central part of the Tekao shield over an unconfined boundary, corresponding to the lower compartment of this fault (Merle et al., 2006). Mapping relationships allow us to estimate the volume of the Taiohae post-shield volcano to $45 \pm 5 \mathrm{~km}^{3}$, i.e. $28 \%$ of the emerged volume of the edifice $\left(160 \mathrm{~km}^{3}\right)$, but only $0.6 \%$ of its total volume $\left(6,950 \mathrm{~km}^{3}\right.$, Chauvel et al., 2012). Lavas 
from the Taiohae volcano include, from bottom to top: olivine tholeiites more enriched in incompatible element than those of the Tekao shield; alkali basalts and a few basanites; and large amounts of hawaiites and mugearites, which cover $47 \%$ of its surface, together with benmoreites and trachytes $(25 \%$ of its surface). In addition, parasitic vents erupted hawaiitic (3.93 Ma) and trachytic (3.92 Ma) flows on the external slopes of the Tekao shield. All the Taiohae post-shield lavas are more radiogenic in $\mathrm{Sr}$ and $\mathrm{Nd}$ and less radiogenic in $\mathrm{Nd}$ than the Tekao ones. Hawaiites and mugearites likely derived from the fractional crystallization from mafic magmas involving separation of amphibole (Legendre et al., 2005b). The isotopic signature of benmoreites and trachytes is closer to the enriched mantle II (EM II) end-member than that of mafic lavas, a feature inconsistent with simple fractionation processes.

\subsubsection{Ua Huka}

Despite its moderate size $\left(83 \mathrm{~km}^{2}\right)$, Ua Huka Island (Legendre et al., 2006; Blais et al., 2008, Chauvel et al., 2012) displays a relatively prolonged, multi-phase geological evolution. Like Nuku Hiva, it has a semicircular shape due to the collapse of the southern half of its outer shield, the Hikitau volcano. It is made up of olivine tholeiitic flows emplaced between 3.24 and 2.94 Ma. The Hane inner (post-shield) volcano was built inside the central caldera of the Hikitau shield between 2.97 and 2.43 Ma (Fig. 4). Its alkali basaltic flows derived from a spinel Iherzolite source similar to that of the Hikitau tholeiites but having experienced smaller degrees of melting (Legendre et al., 2006). Associated benmoreitic flows and trachytic and phonolitic domes were simultaneously emplaced (between 2.93 and $2.71 \mathrm{Ma}$ ) within the Hane post-shield volcano and from parasitic vents located on the outer slopes of the Hikitau shield. Then, after a $1.3 \mathrm{Myr}$ long quiescence period (Fig. 2), volcanic activity resumed, building over the inner slopes of the Hane volcano two basanitic strombolian cones, the Teepoepo (1.15-0.96 Ma) and the Tahoatikikau (0.82-0.76 Ma). Their lavas originated from temporally decreasing melting degrees of a garnet lherzolite source deeper and isotopically more depleted than that of the older Ua Huka tholeiitic and alkali basalts (Chauvel et al., 2012). The origin of this rejuvenated volcanism (the single case identified so far in the archipelago) has been attributed to a secondary melting zone located downstream the Marquesas plume (Legendre et al., 2006), similar to that envisioned by Ribe and Christensen (1999) for the Hawaiian islands. The volumes (estimated from mapping relationships) of the Hane post-shield volcano $\left(6 \pm 1 \mathrm{~km}^{3}\right)$ and the rejuvenated cones $\left(0.6 \pm 0.1 \mathrm{~km}^{3}\right)$ correspond respectively to $21 \%$ and $2 \%$ of the total emerged volume of Ua Huka $\left(28 \mathrm{~km}^{3}\right)$, and less than $0.2 \%$ only of the bulk volume of the edifice $\left(3,250 \mathrm{~km}^{3}\right)$.

The $105 \mathrm{~km}^{2}$ diamond-shaped island of Ua Pou (Legendre et al., 2005a; Guille et al., 2010) is famous 230 spectacular phonolitic spines (Ua Pou means "The Pillars" in Marquesan). Its oldest lavas are olivine tholeiite flows derived from a young HIMU-type mantle source (Duncan et al., 1986, Vidal et al., 1987). They

232 outcrop in a very small area near Hakahau village in the northeast part of the island. The base of their ca 40 $233 \mathrm{~m}$ thick pile (Guille et al., 2010) is not accessible presently but has been dated at 5.61, 4.51 and 4.46 Ma by 
234 the ${ }^{40} \mathrm{~K}-{ }^{40} \mathrm{Ar}$ method on whole rocks (Duncan et al., 1986). Its presently exposed top flow was dated at 4.00 $235 \mathrm{Ma}$ by the unspiked ${ }^{40} \mathrm{~K}-{ }^{40} \mathrm{Ar}$ method on groundmass (Legendre et al., 2005a). These Hakahau tholeiitic 236 flows are overlain either by up to $100 \mathrm{~m}$ thick laharic deposits or by trachytic and phonolitic domes dated at 2373.86 and 3.27 Ma (Guille et al., 2010). The latter sequence is in turn overlain by a strongly silica238 undersaturated lava suite forming the bulk of the island and dated between 2.95 and $2.35 \mathrm{Ma}$ (unspiked ${ }^{40} \mathrm{~K}$ -

$239{ }^{40} \mathrm{Ar}$ ages). It includes from bottom to top: (1) basanitic and tephritic lava flows with intercalated laharic 240 deposits, (2) lower phonolitic flows and intrusions, (3) basanitic and intermediate (tephritic, tephriphonolitic 241 and benmoreitic) flows with occasional interbedded phonolites, (4) upper phonolitic flows, up to $500 \mathrm{~m}$ thick, 242 and finally (5) phonolitic domes and spines, the summit of which tower several hundred meters above the 243 older units. The basanitic magmas of this suite derived from low degrees of melting of an heterogeneous 244 mantle source intermediate between EM II and HIMU end-members, and evolved towards tephritic liquids by 245 fractional crystallization (Legendre et al., 2005a). The origin of tephriphonolitic and benmoreitic magmas was ascribed to the remelting at depth of basanitic rocks, leaving an amphibole-rich residuum (Legendre et al., 2005a). These liquids evolved by either closed-system or more commonly open-system fractionation towards phonolitic and trachytic magmas.

In contrast with the other Marquesas Islands, the main Ua Pou volcanic sequence (2.95-2.35 Ma) does not include a basaltic shield. We therefore support Duncan et al.'s (1986) suggestion that the Ua Pou shield is mainly below sea level, with only its uppermost tholeiitic part presently exposed, and that the rest of the island belongs to the post-shield phase. This interpretation is supported by the occurrence of thick laharic deposits overlying the tholeiitic flows, which indicate an erosional event. However, the temporal hiatus between the shield and post-shield phases (only between 4.00 and 3.86 Ma according to Guille et al., 2010) is much shorter than that proposed by former authors: $1.58 \mathrm{Myr}$ calculated using Duncan et al.'s (1986) data and 2.34 Myr according to Woodhead (1992).

\section{New geological, geochemical and K-Ar age data on the southern Marquesas islands.}

\subsection{Methods}

The analytical techniques are identical to those used to study the northern islands. Unspiked ${ }^{40} \mathrm{~K}$ ${ }^{40} \mathrm{Ar}$ ages were obtained at the LSCE (Laboratoire des Sciences du Climat et de l'environnement) in Gif-sur-Yvette. Fresh and well-crystallized samples were selected for dating after macroscopic and microscopic inspections allowing us to check the lack of post-magmatic mineral phases. In addition, the degree of alteration of these samples was estimated from their loss on ignition value (LOI). For 40 out of 45 dated samples (Tables 2 and 4 ) LOI ranges from -0.39 to 1.56 wt $\%$ and these samples are considered as essentially unaltered. The 5 other samples (HV81, HV99, MT11,TH35 and FH30) have LOI between 1.90 and 2.77 wt\%. Despite their higher LOI, we selected them because of their critical geological position or their unusual composition (tephriphonolitic sample TH35). The samples were crushed and sieved to $0.250-0.125 \mathrm{~mm}$ size fractions, and ultrasonically washed in acetic acid $(1 \mathrm{~N})$ during 45 minutes at a temperature of $60^{\circ} \mathrm{C}$ to remove unsuspected minute amounts of secondary mineral phases. Potassium and argon were measured on the microcrystalline groundmass, after removal of phenocrysts using heavy liquids and magnetic separations. This process removes at least 
some potential sources of systematic error due to the presence of excess ${ }^{40} \mathrm{Ar}$ in olivine and feldspar phenocrysts (Laughlin et al., 1994). The K content of the separated groundmass was measured by ICP-AES in Plouzané using the same method as for major elements while Ar analyses were performed in Gif-sur-Yvette using the procedures of Guillou et al. (2011). Ages given in Tables 1 and 3 were calculated using the constants recommended by Steiger and Jäger (1977). Unspiked K-Ar analysis of each sample involved three independent determinations of potassium and two of argon. Based on replicate analysis of material references, the potassium concentrations were determined with an uncertainty of $1 \%(1 \sigma)$. These potassium concentrations were averaged to yield a mean value. Age determinations of each sample were made using this mean value and the weighted mean of the two independent measurements of ${ }^{40} \mathrm{Ar}^{*}$ (radiogenic argon). Analytical uncertainties for the Ar data are $1 \sigma$, and consist of propagated and quadratically averaged experimental uncertainties arising from the ${ }^{40} \mathrm{Ar}$ (total) and ${ }^{40} \mathrm{Ar}{ }^{*}$ determinations (see Westaway et al., 2005 for more details). Uncertainties on the ages are given at $2 \sigma$.

Before chemical analyses, all samples were crushed using an agate mortar. Major and trace element data (Tables 2 and 4) were obtained by Inductively Coupled Plasma-Atomic Emission Spectrometry (ICPAES) at IUEM, Plouzané using the method of Cotten et al. (1995). The international standards used for calibration were ACE, BEN, JB-2, PM-S and WS-E and the relative standard deviations are $\pm 1 \%$ for $\mathrm{SiO}_{2}$, and $\pm 2 \%$ for other major elements except $\mathrm{P}_{2} \mathrm{O}_{5}$ and $\mathrm{MnO}$ (absolute precision $\pm 0.01 \%$ ). Samples were classified according to their position in the TAS diagram (Fig. 3). Within the basalt group, silica-saturated or oversaturated lavas (normative hy + ol or $h y+Q$ ) were called tholeiitic basalts while nepheline-normative samples were called alkali basalts (normative compositions given in Tables 2 and 4). Some tholeiitic basalts plot close to or even above the Macdonald and Katsura's (1964) boundary in Figure 3 and could therefore be considered as transitional basalts. We did not include the latter category in our classification chart because it has not been previously used in the Marquesas and is not defined rigorously.

\subsection{Hiva Oa}

Hiva Oa $\left(320 \mathrm{~km}^{2}\right)$, the second largest Marquesas island and the highest one (1276 $\mathrm{m}$ at Mt Temetiu), has a WSW-ENE elongated shape parallel to the MFZ (Fig. 1). New field data (Fig. 5) combined with 20 new unspiked ${ }^{40} \mathrm{~K}-{ }^{40} \mathrm{Ar}$ ages (Table 1) show that the island consists in four coalescent volcanoes whose age decreases eastwards from $2.55 \pm 0.05$ to $1.46-1.44 \pm 0.03 \mathrm{Ma}$ (Figs. 4 and 5). All of them are made up of tholeiitic basalts, some of which display a transitional affinity, and hawaiites (Table 2). Alkali basalts and basanites were not identified in our set of 87 newly collected samples (Maury et al., 2012) nor in previous samplings by R. Brousse (Chauvel et al., 2012, their Supplementary file D). Mugearites, benmoreites and trachytes (Table 2) occur only in the post-shield Ootua volcano, or as dykes and plugs crosscutting the Puamau shield.

The oldest volcano, Taaoa, is located on the western coast of Hiva Oa (Fig. 5). It represents the crescent-shaped remnants of a largely collapsed shield, which are unconformably overlain by the flows of the much bigger Temetiu shield. The Taaoa edifice is formed by a monotonous pile of meter-thick tholeiitic 
313 village, was dated at $2.55 \pm 0.05 \mathrm{Ma}$ (HV64, Table 1 and Fig. 4). Taaoa basalts have lower $\mathrm{K}$ contents, lower $314{ }^{87} \mathrm{Sr} /{ }^{86} \mathrm{Sr}$ and higher ${ }^{206} \mathrm{~Pb} /{ }^{204} \mathrm{~Pb}$ ratios compared to all other Hiva Oa basalts, and their trace element and 315 isotopic signatures are closer to HIMU (Chauvel et al., 2012). They plot within the "Ua Pou" trend unlike all 316 other lavas that plot in the "Ua Huka" trend. Accordingly, the $\mathrm{N} 65^{\circ} \mathrm{W}$ limit between the two isotopic stripes defined by Chauvel et al. (2012) has been set at Taaoa village.

The Temetiu shield (Fig. 5) is the largest volcano of Hiva Oa. It is made of a more than 1,200 m thick pile of meter-thick quartz or olivine normative tholeiites and hawaiites (Table 2). The construction of its exposed part started around 2.27 $\pm 0.05 \mathrm{Ma}$ (HV87, foot of Mt Temetiu) and 2.25 $\pm 0.05 \mathrm{Ma}$ (HV84, northern slopes near Hanaiapa village). Its major activity occurred between $2.13 \pm 0.05$ and $1.91 \pm 0.04 \mathrm{Ma}$, based on seven unspiked ${ }^{40} \mathrm{~K}-{ }^{40} \mathrm{Ar}$ ages (Table 1 and Fig. 4). Its well-exposed semicircular caldera facing south collapsed before $2.01 \mathrm{Ma}$. Indeed, this event was followed by landslides which generated avalanche and debris flow deposits, later crosscut by a number of dykes, including HV99 (2.01 $\pm 0.04 \mathrm{Ma})$ south of Atuona village. Volcanic activity of the Temetiu shield ended at $1.83 \pm 0.04 \mathrm{Ma}$ (sample HV81 north of Hanapaaoa village). It was almost immediately followed by the emplacement at $1.80 \pm 0.04 \mathrm{Ma}$ (sample HV65) of a thick pile of post-shield tholeitic flows (the Atuona flows) within the caldera, east and north of Atuona village. Temetiu shield and Atuona post-shield tholeiitic flows share the same isotopic signature typical of the "Ua Huka" stripe (Chauvel et al., 2012). The origin of the collapse of the southern part of these edifices is attributed to the lateral spreading of an hydrothermal zone located beneath the Temetiu caldera over an unconfined boundary corresponding to the lower compartment of a fault parallel to the MFZ (Maury et al., 2013), such as in the case of Nuku Hiva.

The Puamau shield forms the eastern part of Hiva Oa (Fig. 5). Its lower part is made up of an up to 500 $\mathrm{m}$ thick pile of meter-thick flows of quartz tholeiites, olivine tholeiites and interbedded hawaiites dipping gently towards the Temetiu shield or the southern coast. They are dated at $1.65 \pm 0.04$ (HV70) and $1.62 \pm$ $0.04 \mathrm{Ma}$ (HV62). They are overlain by a $200 \mathrm{~m}$ thick pile of tholeiitic basalts and minor interbedded hawaiites occurring as thicker (5-20 m) and usually columnar-jointed flows (Puamau shield upper flows in Fig. 5). Although this unit is younger ( $1.46 \pm 0.03 \mathrm{Ma}$, sample HV88) than the main shield, we do not consider it as belonging to the post-shield stage. Indeed, both were affected by the collapse event that led to a caldera open NE, with its center near the village of Puamau (Fig. 5). Post-caldera volcanic edifices have not been identified within this caldera, but several small benmoreitic and trachytic dykes and plugs (not shown in the simplified geologic map of Fig. 5) crosscut the Puamau shield pile. They are usually altered and therefore unsuitable for ${ }^{40} \mathrm{~K}-{ }^{40} \mathrm{Ar}$ dating.

The Ootua post-shield edifice was emplaced on the eastern slopes of the Temetiu shield. Its central unit, ca $200 \mathrm{~m}$ thick, is exclusively made up of intermediate (mugearitic, benmoreitic and phonotephritic) and silica-oversaturated trachytic flows and N-S trending dykes. It culminates at Mt Ootua, a $500 \mathrm{~m}$ wide and $200 \mathrm{~m}$ high columnar-jointed dome of quartz normative trachyte. This unit is dated at $1.73 \pm 0.04 \mathrm{Ma}$ (HV56 mugearitic flow) and $1.64 \pm 0.03 \mathrm{Ma}$ (HV54 benmoreitic dyke). Its peripherical unit consists of an up to 400 $\mathrm{m}$ thick pile of fissure erupted tholeiitic and hawaiitic flows. Most of these flows display well-developed basal

350 autoclastic breccias. They flow over either (1) the northern and southern slopes of the Temetiu shield, (2) its 351 caldera within which they overlie the Atuona post-shield flows, and finally (3) towards the topographic trough 
separating the Temetiu and Puamau shields (Fig. 5). They fill most of this trough, flowing either towards the northern coast or the southern coast where a tholeiitic basalt (HV107) yields the youngest age measured in Hiva Oa $(1.44 \pm 0.03 \mathrm{Ma})$. Another young age of $1.51 \pm 0.03 \mathrm{Ma}$ has been obtained on an hawaiitic flow (HV86) overlying the Temetiu shield.

The volumes (estimated from mapping relationships) of the Atuona and Ootua post-shield lavas (14 \pm 1 $\mathrm{km}^{3}$ ) correspond to $9.5 \%$ of the total emerged volume of Hiva Oa $\left(145 \mathrm{~km}^{3}\right.$ ), and $0.2 \%$ of the bulk volume of the edifice $\left(6,900 \mathrm{~km}^{3}\right.$, Chauvel et al., 2012).

\subsection{Motane and Tahuata}

Motane (Figs. 1 and 5) is a small $\left(13 \mathrm{~km}^{2}\right)$ crescent-shaped uninhabited island located southeast of Hiva $\mathrm{Oa}$ and east of Tahuata. Like Eiao, it corresponds to a sector of the caldera wall (up to $500 \mathrm{~m} \mathrm{high}$ ) and the upper external slopes of a largely collapsed shield volcano. It is made up of a monotonous pile of meterthick quartz and olivine tholeiitic flows, interbedded with picrobasalts and minor hawaiites. This pile is crosscut by a dense network of radial dykes, which include alkali basalts and basanites (Fig. 4) displaying incompatible element patterns more fractionated than those of the tholeiites. Two tholeitic flows from the middle part of the pile are dated at $1.59 \pm 0.04 \mathrm{Ma}$ (MT04, altitude $120 \mathrm{~m}$ ) and $1.53 \pm 0.03 \mathrm{Ma}$ (MT08, altitude $190 \mathrm{~m}$ ) (see Table 3). An alkali basaltic dyke collected at sea level yields an older age (1.96 \pm 0.04 $\mathrm{Ma}, \mathrm{MT11}$ in Table 3) that is barely consistent with the others and may indicate sample contamination by seawater (also consistent with its relatively high LOI of 2.53 wt\%). The isotopic $\mathrm{Sr}, \mathrm{Nd}, \mathrm{Pb}$ compositions of tholeiites MT04 and MT08 are typical of the "Ua Pou" stripe (Chauvel et al., 2012), as well as that of basanitic sample MT12 that is clearly more radiogenic in $\mathrm{Sr}$ and less radiogenic in $\mathrm{Nd}$ than the tholeiites.

Tahuata $\left(69 \mathrm{~km}^{2}\right)$ corresponds to the northwestern half of a large shield known as the Vaitahu shield (Maury et al., 2013). Its southern part has collapsed over an unconfined boundary. The latter probably corresponds to the SE down-faulted block, lowered by $1,000 \mathrm{~m}$, of a major $\mathrm{N} 35^{\circ} \mathrm{E}$ fault lineament wellidentified off the SE coast of the island (Maury et al., 2013). This collapse event led to the formation of an 8 km large caldera opened toward SE (Fig. 5). A small edifice, the inner Hanatetena volcano (Figs. 4 and 5) grew inside this caldera. The caldera wall was later affected by large landslides, which generated an up to $300 \mathrm{~m}$ thick pile of avalanche and debris flow deposits. The latter partly filled up the topographic trough separating the foot of the caldera wall from the Hanatetena post-shield edifice.

The $700 \mathrm{~m}$ thick lower unit of the Vaitahu shield consists of meter-thick basaltic and hawaiitic flows. The unspiked ${ }^{40} \mathrm{~K}-{ }^{40} \mathrm{Ar}$ ages (Table 3) indicate that it was emplaced rather quickly, between $2.11 \pm 0.05 \mathrm{Ma}$ (TH39 tholeiitic basalt, western coast south of Hapatoni village) and $1.81 \pm 0.04 \mathrm{Ma}$ (TH14 alkali basalt, northern coast). Three ages clustering around $1.90 \mathrm{Ma}$ (TH37, TH38 and TH18 tholeiitic basalts, central part of the island) may record the paroxysmal event. This lower unit is overlain by a pile of thick $(>10 \mathrm{~m})$ and usually columnar-jointed tholeiitic flows. This upper unit forms the central ridge of the island, and is up to 500 $\mathrm{m}$ thick. Its basal flow has an age of $1.88 \pm 0.04 \mathrm{Ma}$ (TH13). We consider it as the upper part of the Vaitahu shield, because (1) it conformably overlies the top of the lower unit, (2) its age is similar to that of the main 
building phase of the lower unit between $1.91 \pm 0.04$ and $1.88 \pm 0.04 \mathrm{Ma}$, and (3) it was obviously affected by the caldera collapse event, as it forms presently the uppermost slopes of the caldera wall (Fig. 5).

A specific feature of the Vaitahu shield is its chemical heterogeneity. It is mostly tholeiitic (18 quartz tholeiites and olivine tholeiites in our sample set), but also includes alkali basalts (2 samples), basanites (3 samples) and hawaiites ( 3 samples). Alkali basalts and basanites are more sodic and more enriched in the most incompatible elements compared to the tholeiites (Table 4), and they display consistently higher ${ }^{87} \mathrm{Sr} /{ }^{86} \mathrm{Sr}$ and lower ${ }^{143} \mathrm{Nd} /{ }^{144} \mathrm{Nd}$ and ${ }^{206} \mathrm{~Pb} /{ }^{207} \mathrm{~Pb}$ ratios according to data obtained on the same samples (Chauvel et al., 2012).

The small (less than $200 \mathrm{~m}$ high) post-caldera Hanatetena volcano is composed exclusively of tholeitic and hawaiitic flows. The basal flows display pahoehoe and lava tube features; they are overlain by highly weathered flows of meter thickness. Their trace element and isotopic compositions plot within the range of the Vaitahu shield tholeiites (Chauvel et al., 2012). Two flows are dated at $1.80 \pm 0.04 \mathrm{Ma}$ (TH31) and $1.74 \pm$ $0.04 \mathrm{Ma}$ (TH8). The exposed volume of the Hanatetena edifice $\left(0.5 \pm 0.1 \mathrm{~km}^{3}\right)$ represents only $2 \%$ of the volume of Tahuata island $\left(25 \mathrm{~km}^{3}\right)$.

The single intermediate/evolved lava documented in Tahuata is a columnar-jointed tephriphonolitic spine, $200 \mathrm{~m}$ in diameter, which crosscuts the northern slopes of the Vaitahu shield and forms the summit of Mt Tumu Meae Ufa $(1,050 \mathrm{~m})$. Because of its young age (1.78 $\pm 0.04 \mathrm{Ma}$, sample TH35), we relate its emplacement to the post-shield stage.

\subsection{Fatu Hiva}

Fatu Hiva Island $\left(84 \mathrm{~km}^{2}\right)$ displays a typical semicircular shape. It includes an external (outer) shield, the Touaouoho volcano, truncated by a $8 \mathrm{~km}$ wide caldera opening westwards, inside which grew a smaller post-caldera edifice, the Omoa volcano (Fig. 5). As in Tahuata, the caldera wall was affected by landslides which generated avalanche and debris flow deposits up to $250 \mathrm{~m}$ thick. These deposits now outcrop within the topographic trough separating the outer shield from the inner Omoa post-shield edifice. The drowning of the western half of the island and the development of the caldera are probably related to major sector collapse events, marked in the regional bathymetry by a $15 \mathrm{~km}$ wide trough (at 2,500 m depth) located west of Fatu Hiva, downslope from the Omoa volcano.

The Touaouoho shield has an up to $1,100 \mathrm{~m}$ thick rather monotonous pile of meter-thick flows of olivine tholeiites, tholeiitic picrobasalts and minor hawaiites (Table 4), crosscut by a dense network of radial inframetric tholeiitic dykes. Their unspiked ${ }^{40} \mathrm{~K}-{ }^{40} \mathrm{Ar}$ ages (Table 3) range from $1.81 \pm 0.04 \mathrm{Ma}$ (FH13) to 1.35 $\pm 0.03 \mathrm{Ma}$ (FH18). The Omoa post-caldera edifice is composed of a $700 \mathrm{~m}$ thick pile of inframetric tholeitic flows, with lava tubes in pahoehoe composite flows. Their ages (Table 3) range from $1.43 \pm 0.03 \mathrm{Ma}$ (FH08)

422 to $1.23 \pm 0.04 \mathrm{Ma}$ (FH05). In addition, a tholeiitic dyke (FH30) crosscutting the debris flow deposits at 423 Hanavave village yielded an age of $1.41 \pm 0.03 \mathrm{Ma}$, consistent with the end of volcanic activity in Touaouoho 424 shield and the initiation of that of the post-shield Omoa edifice. These two stages led to the emplacement of 425 rather similar tholeiitic basalts and hawaiites (Table 4). Their major, trace element (Table 4) and isotopic Sr 
$\mathrm{Nd} \mathrm{Pb}$ and $\mathrm{Hf}$ compositions largely overlap, and both are typical of the predominantly EM II-HIMU sources of the southwestern trend, which has been labelled the "Fatu Hiva group" (Chauvel et al., 2012).

The youngest Fatu Hiva lavas are two well-preserved trachytic domes (Figs. 4 and 5) crosscutting and overlying the Touaouoho shield flows on the northern coast (FH16, $1.11 \pm 0.02 \mathrm{Ma})$ and east of Omoa village (FH06, $1.22 \pm 0.03 \mathrm{Ma}$ ). In addition, a $15 \mathrm{~m}$ wide trachytic dyke (FH12) crosscutting the basal flows of Omoa post-shield edifice is dated at $1.38 \pm 0.03 \mathrm{Ma}$, and was therefore emplaced during the post-shield stage. The volumes (estimated from mapping relationships) of the Omoa post-shield lavas $\left(5 \pm 1 \mathrm{~km}^{3}\right)$ correspond to $28 \%$ of the total emerged volume of Fatu Hiva $\left(28 \mathrm{~km}^{3}\right)$, and $0.2 \%$ only of the bulk volume of the edifice $\left(2,800 \mathrm{~km}^{3}\right)$.

\section{Discussion}

\subsection{Timing of eruptions: no gap between shield-building and post-caldeira stages}

The new unspiked ${ }^{40} \mathrm{~K}-{ }^{40} \mathrm{Ar}$ ages plotted against the distances of the islands to the MFZR along the $\mathrm{N} 65^{\circ} \mathrm{W}$ direction of movement of the Pacific plate (Fig. 2) are reasonably consistent with its local motion rate of $10.5 \mathrm{~cm} /$ year, as previously pointed out by Legendre et al. (2006). These new ages display much less scatter than the age-distance to the MFZR plots using the main $\mathrm{N} 30-40^{\circ} \mathrm{W}$ trend of the chain and all the available ${ }^{40} \mathrm{~K}-{ }^{40} \mathrm{Ar}$ ages measured on bulk rocks (Brousse et al., 1990; Desonie et al., 1993; Guille et al., 2002). The dashed line in Fig. 2, which corresponds to distances to the unexplored seamount chain located ca $50 \mathrm{~km}$ north of the MFZR (Fig. 1), provides a better fit to the start of activity in some islands. Thus, this seamount chain is a strong candidate for the present-day location of the Marquesas hotspot. Overall, Ua Huka differs from all the other islands by the fact that the emplacement of the exposed part of its shield started clearly later than predicted by the hotspot hypothesis (Fig. 2). It is also the only Marquesas Island showing a rejuvenated volcanic stage (Legendre et al., 2006).

Data plotted in Figures 2 and 4 show that there is no consistent temporal hiatus between the shieldbuilding and post-caldeira activities. Usually the two stages either slighly overlap (Nuku Hiva, Ua Huka, Fatu Hiva) or the gap between them is within the range of analytical uncertainties (Temetiu shield and Atuona post-caldeira lavas in Hiva Oa, Tahuata). In Ua Pou, a marginal hiatus (Guille et al., 2010) is observed between the youngest shield tholeiitic basalt $(4.00 \pm 0.06 \mathrm{Ma})$ and the oldest post-shield phonolite $(3.86 \pm 0.06$ Ma). However, this might be due to sampling bias because of the very small size of the emergent part of the shield that is mostly overlain by lahar deposits. Such a temporal continuity implies that the growth of postshield edifices started immediately after the main caldera collapse event, while eruptive activity was still occurring at least in some parts of the shield volcano. Another striking feature of the data shown in Figure 2 is that contemporaneous volcanism occurred in islands located more than $100 \mathrm{~km}$ away from each other (Fig. 1), e.g. around 2.5 Ma (Ua Huka, Ua Pou, Hiva Oa) or between 2.0 and $1.5 \mathrm{Ma}$ (Hiva Oa, Tahuata, Motane and Fatu Hiva). This feature is consistent with a "classical" plume model involving a $200 \mathrm{~km}$ large summital melting zone (Farnetani and Hoffmann, 2010), and it is also observed in other hotspot-related islands such as the Hawaiian chain (Clague and Dalrymple, 1987), the Society archipelago (Guillou et al., 2005) and the Canaries (Carracedo et al., 1998). However, rejuvenated volcanism is much less common in 
464

465

466

467

468

469

470

471

472

473

474

475

476

477

478

479

480

481

482

483

484

485

486

487

488

489

490

491

492

493

494

495

496

497

498

499

500

501

502

the Marquesas (Ua Huka) than in the Hawaiian chain, the Canaries, Mauritius (Paul et al., 2005) and Samoa (Konter and Jackson, 2012).

\subsection{Evidence for post-shield emplacement of nearly all the intermediate and evolved lavas}

The TAS diagram (Fig. 3) and the age versus $\mathrm{SiO}_{2}$ plot (Fig. 6) show that nearly all the dated lavas more evolved than tholeiitic and alkali basalts, basanites and hawaiites were erupted during the post-shield stage of Marquesan volcanoes. These include rare tephrites (Ua Pou), mugearites (Hiva Oa), benmoreites (Nuku Hiva, Ua Pou, Hiva Oa) and tephriphonolites (Ua Pou, Tahuata), and more abundant trachytes (Nuku Hiva, Ua Huka, Ua Pou, Hiva Oa, Fatu Hiva) and phonolites (Ua Pou, Ua Huka). The only exception is Eiao, in which coring has recovered a $10 \mathrm{~m}$ thick trachytic flow in the Dominique drill hole (Caroff et al., 1995; Maury et al., 2009), at depths of 462 to $472 \mathrm{~m}$ below sea level. It has been dated at $5.44 \pm 0.04 \mathrm{Ma}$, an age perfectly consistent with its position within the Eiao shield pile. This trachyte represents only a very small fraction of the 2,100 m long cored volcanic sequences recovered from the three Eiao deep drillings. However, mugearites (undated) also occur in the three cored sequences, in which they have a total thickness of ca 70 $\mathrm{m}$ (Maury et al., 2009). The origin of Eiao mugearites and trachytes has been ascribed to open-system fractional crystallization of associated alkali basaltic magmas, coupled with assimilation of the oceanic crust underlying the shield (Caroff et al., 1999).

In the other islands, the intermediate and evolved lavas erupted within the post-shield volcanoes (Nuku Hiva, Ua Huka, Ua Pou, Ootua edifice in Hiva Oa). However, some of them outcrop as parasitic domes, spines, plugs or dykes crosscutting the older (outer) volcanic shields: trachytes in Nuku Hiva, Ua Huka, Hiva Oa (within the Puamau shield) and Fatu Hiva, and the tephriphonolitic spine of Mt Tumu Meae Ufa in Tahuata. In Nuku Hiva, Ua Huka and Ua Pou, these trachytes or phonolites and the associated intermediate lavas outcrop together with alkali basalts and/or basanites. Their ${ }^{40} \mathrm{~K}-{ }^{40} \mathrm{Ar}$ ages fall within the range of those of the latter or are slightly younger. In the case of Nuku Hiva, petrogenetic studies (Legendre et al., 2005b) led to the conclusion that trachytes derived from open system fractional crystallization of alkali basalt magmas coupled with assimilation of enriched oceanic crust with an EM II signature. The origin of the unusually abundant phonolites from Ua Pou is thought to result from the fractionation of tephriphonolitic and benmoreitic magmas derived from the remelting of basanitic rocks (Legendre et al., 2005a). In Fatu Hiva, the emplacement of trachytes was contemporaneous with or post-dated that of post-caldera tholeiitic basalts, but the possible petrogenetic relationships between them have not been investigated. The same situation pertains to the Ootua post-shield volcano in Hiva Oa, where a spatial and temporal association of tholeiitic basalts (some of which display a transitional affinity), hawaiites, mugearites, benmoreites and trachytes is exposed (Maury et al., 2013). Evolved lavas were emplaced during the known entire history of the archipelago (Fig. 6): Eiao trachyte is one of the oldest lavas of our set of data and Fatu Hiva ones count among the youngest. Nuku Hiva and Ua Huka trachytes as well as the very abundant Ua Pou phonolites were emplaced between ca 4.0 and $2.5 \mathrm{Ma}$ (Fig. 6).

\subsection{Chemical diversity of shield and post-shield basaltic lavas}

In the Hawaiian model, basaltic magmas derive from temporally decreasing melt fractions of the mantle sources: the emplacement of tholeiitic shield basalts is followed by that of post-shield alkali basalts and then 
503 by rejuvenated basanites or nephelinites, and $\mathrm{Sr}$ isotopic ratios decrease during this evolution (Garcia et al., 504 2010; Hanano et al., 2010). In the Marquesas, Ua Huka island volcanism followed this trend, with the 505 successive emplacement of Hikitau shield tholeiites, Hane post-shield alkali basalts and associated 506 benmoreites, trachytes and phonolites, and finally Teepoepo and Tahoatikikau rejuvenated basanitic cones. 507 However, Hikitau and Hane basalts display similar radiogenic $\mathrm{Sr}$ isotopic compositions, and only the 508 basanites from the rejuvenated cones are less radiogenic (Chauvel et al., 2012). In Ua Pou, the small 509 emergent remnants of an HIMU-type tholeiitic shield are overlain by a thick post-shield pile of basanites, 510 phonolites and other silica-undersaturated lavas more radiogenic in $\mathrm{Sr}$, with a dominant EM II signature 511 (Duncan et al., 1986; Vidal et al., 1987; Legendre et al., 2005a).

512 The temporal petrologic evolution of other islands is more complex. Most shield lavas are tholeiitic, but 513 minor amounts of alkali basalts and basanites displaying higher enrichments in incompatible elements and 514 more radiogenic Sr isotopic ratios are interbedded with them in the shields of Eiao and Tahuata, or occur as 515 dykes crosscutting them in the Motane shield. In Nuku Hiva, the large post-shield Taiohae volcano includes 516 olivine tholeiites, alkali basalts and basanites more radiogenic in $\mathrm{Sr}$ than the Tekao shield tholeiites 517 (Legendre et al., 2005b). Post-shield basaltic lavas are exclusively tholeiitic or transitional in Hiva Oa 518 (Atuona and Ootua units), Tahuata (Hanatetena) and Fatu Hiva (Omoa). Although displaying a rather large 519 isotopic variability, they fall within the range of shield tholeiites from the same islands (Chauvel et al., 2012).

520 As a whole, the claim by Woodhead (1992) and Castillo et al. (2007) that Marquesas shield lavas have 521 systematically lower ${ }^{87} \mathrm{Sr}{ }^{86} \mathrm{Sr}$ ratios than post-shield lavas is not supported by isotopic studies conducted on 522 our sample set (Chauvel et al., 2012). This conclusion applies to islands from the two isotopic groups, e.g. to 523 Eiao and Ua Huka in the "Ua Huka group" and Hiva Oa, Tahuata and Fatu Hiva in the "Fatu Hiva group" 524 (Chauvel et al., 2012). The isotopic features of the sources of the Marquesas lavas are therefore not related 525 to the temporal pattern of volcanism (shield/post-shield activities) in a given island. The mafic lavas from the 526 two groups display similar La/Yb ratios (Fig. 7), while the Ua Huka rejuvenated basanites exhibit higher 527 ones. Post-shield intermediate and evolved lavas are more scattered in Fig. 7, probably because of their 528 complex petrogenesis (open-system fractionation or remelting of mafic magmas). In a similar La/Yb versus 529 La plot in which samples are sorted by petrographic type, alkali basalts display La/Yb ratios higher than 530 those of tholeiites (Chauvel et al., 2012, their Figure 6).

\section{$531 \quad$ 4.4. Implications for Marquesas plume heterogeneity and hotspot models}

$532 \quad$ Hotspot models previously proposed for the Marquesas (Duncan et al., 1986; Woodhead, 1992; Desonie 533 et al., 1993; Castillo et al., 2007) involved melting of a heterogeneous zoned mantle plume and of the 534 overlying oceanic lithosphere, or interactions between ascending plume-derived melts and this lithosphere. 535 These models were based on the assumption that the archipelago followed an "Hawaiian-type" temporal 536 evolution, the main difference being that in the Marquesas shield tholeitic basalts were less radiogenic in $\mathrm{Sr}$ 537 (closer to DMM and/or HIMU) than the post-shield alkalic lavas (closer to EM end-members). In addition, 538 some authors used the tholeitic or alkalic compositions of the basalts (Woodhead, 1992) or even their Sr 539 isotopic ratios (Castillo et al., 2007) to classify them as shield or post-shield, which led to additional 540 confusion. 
In the present study and in the Chauvel et al. paper (2012), we used exclusively geological (field relationships determined from detailed mapping) and chronological (unspiked ${ }^{40} \mathrm{~K}-{ }^{40} \mathrm{Ar}$ ages) data to determine the shield or post-shield position of the samples. Our results show that: (1) there was usually no temporal gap between shield and post-shield activities at a given island;

(2) eruptions occurred simultaneously in islands distant as much as $100 \mathrm{~km}$ one from another; (3) although most shields are tholeiitic, several of them (Eiao, Tahuata) contain interbedded alkali basaltic and basanitic flows; (4) while post-shield intermediate and evolved lavas derive usually from alkali basaltic or basanitic magmas, several post-shield volcanoes are tholeiitic (Hiva Oa, Tahuata, Fatu Hiva); (5) the trace element and isotopic compositions of shield and post-shield tholeiites display large variations, but the two groups overlap in most diagrams (Chauvel et al., 2012); and finally (6) the "Ua Huka" and "Fatu Hiva" isotopic groups involve mixtures of different mantle components, all of them likely located within the plume itself (Chauvel et al., 2012) as also envisioned for Hawaii (Frey et al., 2005; Fekiacova et al., 2007; Garcia et al., 2010; Hanano et al., 2011).

The $\mathrm{Sr}$ and $\mathrm{Nd}$ isotopic differences between tholeiitic basalts and alkali basalts/basanites from Marquesas Islands are shown in Figure 8. This plot shows all the data from the GEOROC database on basaltic lavas whose major element and isotopic data were available. The sources of alkali basalts and basanites are generally more enriched than those of the tholeiites at the scale of the archipelago. This is also true within a given island, although the isotopic contrasts range from huge at Ua Pou to large at Tahuata, Nuku Hiva, and Motane and small at Eiao and Ua Huka. These contrasts are consistent with the hypothesis of an extremely heterogeneous character of the Marquesas plume. The nearly contemporaneous emplacement of tholeiites and alkali basalts with different isotopic compositions in Tahuata (Chauvel et al., 2012) suggests the occurrence of heterogenous mantle domains $10 \mathrm{~km}$ or less in diameter, as envisioned for several other plumes including Hawaii (Marske et al., 2007; Hanano et al., 2010), Mauritius (Paul et al., 2005) and the Galápagos (Gibson et al., 2012). When affected by the same high thermal regime in the central part of a plume, domains with contrasted lithologies could experience variable degrees of melting, generating the observed diversity of basaltic magmas. Especially, low-degree melts might sample preferentially fertile (and isotopically enriched) pyroxenite while the signature of the more depleted peridotitic source dominates in high-degree melts (Sobolev et al., 2005, 2007; Jackson and Dasgupta, 2008; Day et al., 2009; Dasgupta et al., 2010; White, 2010; Davis et al., 2011; Herzberg, 2011).

The occurrence of tholeiitic post-shield basalts in several islands is not surprising given the temporal continuity between the shield and post-shield stages and the usually short period of emplacement of these post-shield tholeiites ( $<0.1 \mathrm{Ma}$ in Tahuata, Nuku Hiva and for Ootua basaltic flows in Hiva Oa; $0.2 \mathrm{Ma}$ in Fatu Hiva, Fig. 5 and Tables 1 and 3). It is likely that during such short time spans the extent of melting of the plume at depth did not change significantly, while the volcano structure was considerably modified after the caldera collapse event. Longer post-shield activities might record a decrease of melting and possible preferential sampling of enriched materials. In the Taiohae inner edifice (Nuku Hiva) where post-shield activity lasted ca $0.4 \mathrm{Ma}$ (from 4.00 to $3.62 \mathrm{Ma}$; Maury et al., 2006), a brief tholeiitic episode was followed by the emplacement of alkali basalts and basanites, and then by that of mugearites, benmoreites and trachytes derived from an enriched mantle source. A rather similar evolution has been documented in the post-shield volcanism of Mauna Kea, Hawaii (Frey et al., 1990), where the initial emplacement of tholeiites and alkali 
basalts (basaltic substage) was followed by that of intermediate and evolved lavas (hawaiitic substage). Finally, the emplacement of the rejuvenated basanitic strombolian cones in Ua Huka after a 1.3 Myr long quiescence period (Fig. 2) was accompanied by major petrogenetic changes, involving very low melting degrees of a garnet Iherzolite source deeper and isotopically more depleted than that of the older tholeitic and alkali basalts (Legendre et al., 2006).

The petrologic and geochemical diversity of Marquesas lavas is rather exceptional given the modest size of the archipelago, as appreciated since the pioneer works of A. Lacroix (1928) and L.J. Chubb (1930). It can be related to the "weak" character of the Marquesas plume (McNutt et al., 1989), which produced "only" 7,700 km $\mathrm{km}^{3}$ of magma per Myr in the Marquesas (Chauvel et al., 2012), compared to $213,000 \mathrm{~km}^{3}$ for the Big Island of Hawaii (Robinson and Eakins, 2006). Indeed, low degrees of partial melting resulted in the preservation in the Marquesas basaltic magmas of geochemical features inherited from small-size source heterogeneities, while high degrees of partial melting and resulting high magma production rate tend to blend these features. The complex petrogenesis (open-system processes or remelting of mafic precursors) of post-shield intermediate and evolved lavas contributed further to increase this diversity.

\section{Conclusions}

The study of 110 Marquesas lavas located on detailed geological maps and dated by the unspiked ${ }^{40} \mathrm{~K}$ ${ }^{40} \mathrm{Ar}$ method on separated groundmass allows us to demonstrate that the temporal evolution of the archipelago is rather different with respect to that of Hawaii and many other hotspot-related chains. There is usually no temporal gap between shield and post-shield activities in a given island, and rejuvenated volcanism is uncommon. Although most shields are tholeiitic, several of them (Eiao, Tahuata) contain interbedded alkali basaltic and basanitic flows. The occurrence of intermediate and evolved lavas is restricted to the post-shield stage, with one exception (Eiao). Although these lavas are usually associated with alkali basaltic or basanitic magmas, several post-shield volcanoes are tholeiitic (Hiva Oa, Tahuata, Fatu Hiva) or include tholeiites (Nuku Hiva). In a given island, the trace element and isotopic compositions of shield and post-shield tholeiites overlap although both display large variations (Chauvel et al., 2012).

These features are inconsistent with former models (Duncan et al., 1986; Woodhead, 1992; Desonie et al., 1993; Castillo et al., 2007) that postulated that the Marquesas followed a "Hawaiian-type" evolution. They are consistent with the hypothesis of an extremely heterogeneous character of the Marquesas plume. The "weak" character of this plume led to low degrees of partial melting, which in turn resulted in the preservation in the basaltic magmas of geochemical features inherited from such small-size source heterogeneities.

\section{Acknowledgements}

This study has been funded by CNRS (INSU and UMR 8212, 6538, 5275, 6518), BRGM and CEADASE-DSM. We thank two anonymous reviewers for their very constructive comments that helped us to improve the overall content of the manuscript. We also thank Mayors Guy Rauzy and Etienne Tehaamoana (Hiva Oa), Henri Tuieinui (Fatu Hiva) and Félix Barsinas (Tahuata) who provided logistic support during

617 fieldwork. We are very grateful to Andy Teiki Richmond and the team of the Service du Développement 618 Rural of Atuona-Hiva Oa for their considerable help in the field, especially during coastal sampling and work 
in densely forested areas. Joseph Cotten's contribution to analytical work is greatly appreciated. Jean François Tannau and Vincent Scao provided helpful technical assistance. This is LSCE contribution N5115.

\section{References}

Blais, S., Legendre, C., Maury, R.C., Guille, G., Guillou, H., Rossi, P., Chauvel, C., 2008.

Notice explicative, carte géologique de France, feuille de Ua Huka, Polynésie française, 102 pp, scale 1: 50,000 , Bureau de Recherches Géologiques et Minières, Orléans, France.

Brousse, R., Barsczus, H.G., Bellon, H., Cantagrel, J.M., Diraison, C., Guillou, H., Léotot, C., 1990. Les Marquises (Polynésie française): volcanologie, géochronologie, discussion d'un modèle de point chaud [The Marquesas alignment (French Polynesia) - Volcanology, geochronology, a hotspot model]. Bulletin de la Société géologique de France 6, 933-949.

Cadio, C., Panet, I., Davaille, A., Diament, M., Métivier, L., de Viron, O., 2011. Pacific geoid anomalies revisited in light of thermochemical oscillating domes in the lower mantle. Earth Planetary Science Letters 306, 123-135.

Caress, D.V., McNutt, M.K., Detrick, R.S., Mutter, J.C., 1995. Seismic imaging of hotspot related crustal underplating beneath the Marquesas Islands. Nature 373, 600-603.

Caroff, M., Maury, R.C., Vidal, P., Guille, G., Dupuy, C., Cotten, J., Guillou, H., Gillot, P.Y., 1995. Rapid temporal changes in ocean island basalt composition - evidence from an $800 \mathrm{~m}$ deep drill hole in Eiao shield (Marquesas). Journal of Petrology 36, 1333-1365.

Caroff, M., Guillou, H., Lamiaux, M.I., Maury, R.C., Guille, G., Cotten, J., 1999.

Assimilation of ocean crust by hawaiitic and mugearitic magmas: an example from Eiao (Marquesas). Lithos 46, 235-258.

Carracedo, J.C., Day, S., Guillou, H., Badiola, E.R., Canas, J.A., Pérez Torrado, F.J., 1998. Hotspot volcanism close to a passive continental margin: The Canary Islands. Geological Magazine 135, 591-604.

Castillo, P.R., Scarsi, P., Craig, H., 2007. He, Sr, Nd and Pb isotopic constraints on the origin of the Marquesas and other linear volcanic chains. Chemical Geology 240, 205-221.

Chauvel, C., Maury, R.C., Blais, S., Lewin, E., Guillou, H., Guille, G., Rossi, P., Gutscher, M.-A., 2012. The size of plume heterogeneities constrained by Marquesas isotopic stripes. Geochemistry Geophysics Geosystems 13(1), Q07005, doi: 10.129/2012GC004123.

Chubb, L.J., 1930. The geology of the Marquesas islands. Bernice P. Bishop Museum Bulletin, 68, 1-71.

Clague, D.A., 1987. Hawaiian xenolith populations, magma supply rates, and development of magma chambers. Bulletin of Volcanology 49, 577-587.

Clague, D.A., Dalrymple, G.B., 1987. The Hawaiian-Emperor volcanic chain. Part 1. Geological evolution. United States Geological Survey Professional Paper 1350, 5-54.

Cotten, J., Le Dez, A., Bau, M., Caroff, M., Maury, R.C., Dulski, P., Fourcade, S., Bohn, M., Brousse, R., 1995. Origin of anomalous rare-earth element and yttrium enrichments in subaerially exposed basalts: Evidence form French Polynesia. Chemical Geology 119, 115-138.

Courtillot, V., Davaille, A., Besse, J., Stock, J., 2003. Three distinct types of hotspots in the Earth's mantle. Earth and Planetary Science Letters 205, 295-308.

Crough, S.T., Jarrard, R.D., 1981. The Marquesas-line swell. Journal of Geophysical Research 86, 17631771.

Dasgupta, R., Jackson, M.G., Lee, C.T.A., 2010. Major element chemistry of ocean island 
basalts - Conditions of mantle melting and heterogeneity of mantle source. Earth and Planetary Science Letters 289, 377-392.

Davaille, A., Girard, F., Le Bars, M., 2002. How to anchor hotspots in a convecting mantle ? Earth and Planetary Science Letters 203, 621-634.

Davis, F.A., Hirschmann, M.M., Humayun, M., 2011. The composition of the incipient partial melt of garnet peridotite at $3 \mathrm{GPa}$ and the origin of OIB. Earth and Planetary Science Letters 308, 380-390.

Day, J.M.D., Pearson, D.G., Macpherson, C.G., Lowry, D., Carracedo, J.C., 2009.

Pyroxenite-rich mantle formed by recycled oceanic lithosphere: Oxygen-osmium isotope evidence from Canary Island lavas. Geology 37, 555-558.

Desonie, D.L., Duncan, R.A., Natland, J.H., 1993. Temporal and geochemical variability of volcanic products of the Marquesas hotspot. Journal of Geophysical Research 98, 17649-17665.

Devey, C.W., Haase, K.M., 2003. The sources for hotspot volcanism in the South Pacific Ocean, in: R. Hékinian, P.S., J.L. Cheminée (Ed.), Oceanic hotspots: intraplate submarine magmatism and tectonism. Springer Verlag, Berlin, pp. 253-284.

Duncan, R.A., 1975. Linear volcanism in French Polynesia. Unpublished PhD Thesis, Australian National University.

Duncan, R.A., McDougall, I., 1974. Migration of volcanism with time in the Marquesas Islands, French Polynesia. Earth and Planetary Science Letters 21, 414-420.

Duncan, R.A., McCulloch, M.T., Barczus, H.G., Nelson, D.R., 1986. Plume versus lithospheric sources for the melts at Ua Pou, Marquesas Island. Nature 303, 142-146.

Farnetani, C.G., Hofmann, A.W., 2010. Dynamics and internal structure of the Hawaiian plume. Earth and Planetary Science Letters 295, 231-240.

Fekiacova, Z., Abouchami, W., Galer, S.J.G., Garcia, M.O., Hofmann, A.W., 2007. Origin and temporal evolution of Ko'olau Volcano, Hawai'i: Inferences from isotope data on the Ko'olau Scientific Drilling Project (KSDP), the Honolulu Volcanics and ODP Site 843. Earth and Planetary Science Letters 261, 65-83.

Filmer, P.E., McNutt, M.K., Wolfe, C.J., 1993. Elastic thickness of the lithosphere in the Marquesas and Society Islands. Journal of Geophysical Research 98, 1956519577.

Frey, F.A., Wise, W.S., Garcia, M.O.,West, H., Kwon, S.-T., Kennedy, A., 1990. Evolution of Mauna Kea volcano, Hawaii: petrologic and geochemical constraints on postshield volcanism. Journal of Geophysical Research 95, 1271-1300.

Frey, F.A., Huang, J., Blichert-Toft, J., Regelous, M., Boyet, M., 2005. Origin of depleted components in basalt related to the Hawaiian hot spot: Evidence from isotopic and incompatible element ratios. Geochemistry Geophysics Geosystems 6, Q02107, doi:10.129/2004GC000757.

Garcia, M.O., Swinnard, L., Weis, D., Greene, A.R., Tagami, T., Sano, H., Gandy, C.E., 2010. Petrology, geochemistry and geochronology of Kaua'i lavas over 4.5 Myr: implications for the origin of rejuvenated volcanism and the evolution of the Hawaiian plume. Journal of Petrology 51, 1507-1540.

Gibson, S.A., Geist, D.G., Day, J.A., Dale, C.W., 2012. Short wavelength heterogeneity in the Galápagos plume: evidence from compositionally diverse basalts on Isla Santiago.. Geochemistry Geophysics Geosystems 13(1), Q09007, doi: 10.129/2012GC004244.

Guille, G., Legendre, C., Maury, R.C., Caroff, M., Munschy, M., Blais, S., Chauvel, C., 
Cotten, J., Guillou, H., 2002. Les Marquises (Polynésie française): un archipel intraocéanique

Guille, G., Legendre, C., Maury, R.C., Guillou, H., Rossi, P., Blais, S., 2010. Notice explicative, carte géologique de France, feuille de Ua Pou, Polynésie française, 133 pp, scale 1: 30,000, Bureau de Recherches Géologiques et Minières, Orléans, France, in press.

Guille, G., Maury, R.C., (coordinators), 2013. Carte géologique de la feuille Groupe Sud de l'archipel des Iles Marquises (Hiva Oa - Tahuata - Motane et Fatu Hiva), Polynésie française, scale 1: 100,000, Bureau de Recherches Géologiques et Minières, Orléans, France, in press.

Guillou, H, Maury, R.C., Blais, S., Cotten, J., Legendre, C., Guille, G., Caroff, M., 2005. Age progression along the Society hot spot chain (French Polynesia) based on new unspiked K-Ar ages. Bulletin de la Société géologique Française 176, 135-150.

Guillou, H., Nomade, S., Carracedo, J.C., Kissel, C., Laj, C., Perez Torrado, F.J., Wandres, C., 2011. Effectiveness of combined unspiked $\mathrm{K}-\mathrm{Ar}$ and $40 \mathrm{Ar} / 39 \mathrm{Ar}$ dating methods in the $14 \mathrm{C}$ age range. Quaternary Geochronology 6, 530-538.

Gutscher, M.A., Olivet, J.L., Aslanian, D., Eissen, J.P., Maury, R., 1999. The "lost Inca Plateau": cause of flat subduction beneath Peru? Earth and Planetary Science Letters 171, 335-341.

Hanano, D., Weis, D., Scoates, J.S., Aciego, S., DePaolo, D.J., 2010. Horizontal and vertical zoning of heterogeneities in the Hawaiian mantle plume from the geochemistry of consecutive postshield volcano pairs: Kohala-Mahukona and Mauna Kea-Hualalai. Geochemistry Geophysics Geosystems 11, Q01004, doi:10.129/2009GC002782.

Herzberg, C., 2011. Identification of Source Lithology in the Hawaiian and Canary Islands: Implications for Origins. Journal of Petrology 52, 113-146.

Jackson, M.G., Dasgupta, R., 2008. Compositions of HIMU, EM1, and EM2 from global trends between radiogenic isotopes and major elements in ocean island basalts. Earth Planetary Science Letters 276, 175-186.

Jordahl, K.A., McNutt, M.K., Webb, H.F., Kruse, S.E., Kuykendall, M.G., 1995. Why there are no earthquakes on the Marquesas Fracture Zone. Journal of Geophysical Research 100, 24431-24447.

Konter, J.G., Jackson, M.G., 2012. Large volumes of rejuvenated volcanism in Samoa: evidence supporting a tectonic influence on late-stage volcanism. Geochemistry Geophysics Geosystems 13, Q0AM04, doi:10.129/2011GC003974.

Lacroix, A., 1928. Nouvelles observations sur les laves des îles Marquises et de l'île Tubuai (Polynésie australe). Comptes Rendus de l'Académie des Sciences Paris 187, 365-369.

Laughlin, A.W., Poths, J., Healey, H.A., Reneau, S., Woldegabriel, G., 1994. Dating of Quaternary basalts using the cosmogenic He-3 and C-14 methods with implications for excess Ar-40. Geology 22, $135-138$.

Le Bas, M.J., Le Maitre, R.W., Streckeisen, A., Zanettin, B., 1986. A chemical classification of volcanic rocks based on the total-alkali-silica diagram. Journal of Petrology 27, 745-750.

Legendre, C., Maury, R.C., Caroff, M., Guillou, H., Cotten, J., Chauvel, C., Bollinger, C., Hémond, C., Guille, G., Blais, S., Rossi, P., Savanier, D., 2005a. Origin of exceptionally abundant phonolites on Ua Pou island (Marquesas, french Polynesia): partial melting of basanites followed by crustal contamination. Journal of Petrology 46, 1925-1962.

Legendre, C., Maury, R.C., Savanier, D., Cotten, J., Chauvel, C., Hémond, C., Bollinger, C., Guille, G., Blais, S., Rossi, P., 2005b. The origin of intermediate and evolved lavas in the Marquesas archipelago: an example from Nuku Hiva island (French Polynesia). Journal of Volcanology and Geothermal Research 143, 293-317. 
Legendre, C., Maury, R.C., Blais, S., Guillou, H., Cotten, J., 2006. Atypical hotspot chains: evidence for a secondary melting zone below the Marquesas (French Polynesia). Terra Nova $18,210-216$.

Macdonald, G.A., Katsura, T., 1964. Chemical composition of Hawaiian lavas. Journal of Petrology 5, 82133.

Marske, J.P., Pietruszka, A.J., Weis, D., Garcia, M.O., Rhodes, J.M., 2007. Rapid passage of a small-scale mantle heterogeneity though the melting regions of Kilauea and Mauna Loa volcanoes. Earth and Planetary Science Letters 259, 34-50.

Maury, R.C., Guille, G., Legendre, C., Savanier, D., Guillou, H., Rossi, P., Blais, S., 2006. Notice explicative, carte géologique de France, feuille de Nuku Hiva, Polynésie française. 116 pp, scale 1: 50,000, Bureau de Recherches Géologiques et Minières, Orléans, France.

Maury, R.C., Legendre, C., Guille, G., Demange, J., Caroff, M., 2009.Notice explicative, carte géologique de France, feuille d'Eiao, Polynésie française,89 pp, scale 1:25,000, Bureau de Recherches Géologiques et Minières, Orléans, France.

Maury, R.C., Guille, G., Guillou, H., Rossi, P., Legendre, C., Chauvel, C., Blais, S., Ottino, P., Meyer, J.-Y., Deroussi, S., Tegyey, M., Cabioch, G., 2013. Notice explicative, carte géologique de France, feuille Groupe Sud de l'archipel des lles Marquises (Hiva Oa - Tahuata - Motane et Fatu Hiva), Polynésie française, XX pp, scale 1: 100,000, Bureau de Recherches Géologiques et Minières, Orléans, France, in press.

McDougall, I., Duncan, R.A., 1980. Libnear volcanic chains: recording plate motions? Tectonophysics 63, 275-295.

McNutt, M., Bonneville, A., 2000. A shallow, chemical origin for the Marquesas Swell. Geochemistry Geophysics Geosystems 1, 1999GC000028.

McNutt, M., Fischer, K., Kruse, S., Natland, J., 1989. The origin of the Marquesas fracture zone ridge and its implications for the nature of hot spots. Earth and Planetary Science Letters 91, 381-393.

Merle, O., Barde-Cabusson, S., Maury, R.C., Legendre, C., Guille, G., Blais, S., 2006. Volcano core collapse triggered by regional faulting. Journal of Volcanology and Geothermal Research 158, 269-280.

Paul, D., White, W.M., Blichert-Toft, J, 2005. Geochemistry of Mauritius and the origin of rejuvenescent volcanism on oceanic island volcanoes. Geochemistry Geophysics Geosystems 6, Q06007, doi: 10.129/2004GC000883.

Pautot, G., Dupont, J., 1974. La zone de fracture des Marquises. Comptes Rendus de l'Académie des Sciences Paris 279, 1519-1523.

Ribe N.M, Christensen U.R., 1999. The dynamical origin of Hawaiian volcanism. Earth and Planetary Science Letters 171, 517-531.

Shafer, J.T., Neal, C.R., Regelous, M. 2005. Petrogenesis of Hawaiian postshield lavas: evidence from Nintoku Seamount, Emperor Seamount Chain. Geochemistry Geophysics Geosystems 6, Q05L09, doi: 10.129/2004GC000875.

Smith, W.H.F., Sandwell, D.T., 1997. Global sea floor topography from satellite altimetry and ship depth soundings. Science 277, 1956-1962.

Sobolev, A.V., Hofmann, A.W., Sobolev, S.V., Nikogosian, I.K., 2005. An olivine-free mantle source of Hawaiian shield basalts. Nature 434, 590-597.

Sobolev, A.V., Hofmann, A.W., Kuzmin, D.V.,Yaxley, G.M., Arndt, N.T., Chung, S.-L., Danyushevsky, L.V., Elliott, T., Frey, F.A., Garcia, M.O., Gurenko, A.A., Kamenetsky, V.S., Kerr, A.C., Krivolutskaya, N.A., 
Matvienkov, V.V., Nikogosian, I.K., Rocholl, A., Sigurdsson, I.A., Sushchevskaya, N.M., Teklay, M., 2007. The Amount of Recycled Crust in Sources of Mantle-Derived Melts. Science 316, 412-417.

Stearns, H.T., 1966. Geology of the State of Hawaii: Palo Alto. Pacific Books, 266 p.

862

863

864

865

866

867

868

869

870

Steiger, R.H., Jäger, E., 1977. Subcommission on geochronology: convention on the use of decay constants in geo-and cosmochronology. Earth and Planetary Science Letters 36, 359-362.

Vidal, P., Chauvel, C., Brousse, R., 1984. Large mantle heterogeneity beneath French Polynesia. Nature 307, 536-538.

Vidal, P., Dupuy, C., Barsczus, H.G., Chauvel, C., 1987. Hétérogénéités du manteau et origine des basaltes des Marquises (Polynésie). Bulletin de la Société géologique de France 4, 633-642.

Westaway, R., Guillou, H., Yurtmen, S., Demir, T., Scaillet, S., Rowbotham, G., 2005. Constraints on the timing and regional conditions at the start of the present phase of crustal extension in western Turkey, from observations in and around the Denizli region. Geodinamica Acta. 18/3-4, 209-238.

881

882

883

884

White, W.M., 2010. Oceanic Island Basalts and Mantle Plumes: The Geochemical Perspective, in: Jeanloz, R., Freeman, K.H. (Eds.), Annual Review of Earth and Planetary Sciences, Vol 38. Annual Reviews, Palo Alto, pp. 133-160.

Woodhead, J.D., 1992. Temporal geochemical evolution in oceanic intra-plate volcanics: a case study from the Marquesas (French Polynesia) and comparison with other hotspots. Contributions to Mineralogy and Petrology 111, 458-467. 
Fig. 1. Location map of Marquesas Islands. The bathymetry comes from the global altimetry data set of Smith and Sandwell (1997). The main trend of the Marquesas chain is $\mathrm{N} 40^{\circ} \mathrm{W}$. Current Pacific plate motion is $10.5 \mathrm{~cm} / \mathrm{yr}$ at $\mathrm{N} 65^{\circ} \mathrm{W}$, corresponding to the line shown in white. The names of the southern islands are in large print. MFZ: Marquesas Fracture Zone.

Fig. 2. Age versus distance plot for the Marquesas. The distances to the MFZ Ridge (MFZR) along $\mathrm{N} 65^{\circ} \mathrm{W}$ trend corresponding to the $10.5 \mathrm{~cm} / \mathrm{yr}$ motion of the Pacific plate are from Chauvel et al. (2012). The dashed line starts from the unexplored chain of seamounts located $50 \mathrm{~km}$ NW of the MFZR. Shield ages are denoted by open symbols, post-shield ages by filled symbols and rejuvenated ages by grey symbols. Sources of unspiked ${ }^{40} \mathrm{~K}-{ }^{40} \mathrm{Ar}$ ages on groundmass: Tables 1 and 3 for southern islands; Caroff et al. (1995) and Maury et al. (2009) for Eiao; Maury et al. (2006) for Nuku Hiva; Legendre et al. (2006) and Blais et al. (2008) for Ua Huka; Legendre et al. (2005a) and Guille et al. (2010) for Ua Pou.

Fig. 3. Total-Alkali-Silica (TAS) diagram (Le Bas et al., 1986) for the dated Marquesas lavas. The dashed line separating the fields of tholeiitic (Thol.) and alkali (Alk.) basalts is from Macdonald and Katsura 902 (1964). Shield ages are denoted by open symbols, post-shield ages by filled symbols and rejuvenated ages by grey symbols. Sources of major and trace element analyses: Tables 2 and 4 for southern islands; Caroff et al. (1995) and Maury et al. (2009) for Eiao; Maury et al. (2006) for Nuku Hiva; Legendre et al. (2006) and Blais et al. (2008) for Ua Huka; Legendre et al. (2005a) and Guille et al. (2010) for Ua Pou.

Fig. 4. Sketches of the Marquesas volcanic successions, showing caldera collapse events (red dashed lines) and simplified distributions of tholeiitic basalts, alkali basalts and basanites, and felsic lavas (trachytes and phonolites). Intermediate lavas have been omitted for clarity. Vertical scales are arbitrary. Abbreviated volcano names: Ha: Hane; Hi: Hikitau; Hk: Hakahau; Hn: Hanatetena; Om: Omoa; Oo: Ootua; Pu: Puamau; Ta: Taaoa; Te: Temetiu; Th: Taiohae; Tk: Tekao; To: Touaouoho; Va: Vaitahu. In Ua Huka, a temporal gap separates the end of building of the Hane volcano from the rejuvenated volcanic phase which emplaced the Teepoepo (1.15-0.96 Ma) and Tahoatikikau (0.82-0.76 Ma) basanitic cones. In Tahuata, the horizontal line below the red dashed line separates the upper from the lower tholeiitic flows of Vaitahu shield.

Fig. 5. Geological sketch maps of the southern Marquesas islands, simplified from Guille and Maury (2013) and Maury et al. (2013). The locations of the dated samples are shown by small red crosses (corresponding ages in Ma from Tables 1 and 3). Most flow dips range from 8 to $12^{\circ}$. See text for explanations.

Fig. 6. Plot of unspiked ${ }^{40} \mathrm{~K}-{ }^{40} \mathrm{Ar}$ ages against $\mathrm{SiO}_{2}$ for dated samples. Symbols and sources of data as in Figs. 2 and 3.

Fig. 7. Plot of $L a / Y b$ against $L a(p p m)$ for dated samples. Symbols and sources of data as in Fig. 3. 
Fig. $8 .{ }^{87} \mathrm{Sr} /{ }^{86} \mathrm{Sr}$ versus ${ }^{143} \mathrm{Nd} /{ }^{144} \mathrm{Nd}$ diagram showing the differences between tholeiitic basalts and alkali basalts/basanites from Marquesas islands. Data from the GEOROC database and Chauvel et al. (2012). The Fatu Hiva sample plotting away from the main trend (low $\left.{ }^{143} \mathrm{Nd} /{ }^{144} \mathrm{Nd}\right)$ is from Woodhead $(1992)$.

\section{Table captions}

Table 1. Unspiked ${ }^{40} \mathrm{~K}-{ }^{40} \mathrm{Ar}$ ages measured on groundmass for Hiva Oa lavas. See text for analytical methods and Fig. 4 for sample locations. SH: shield; PS: post-shield. Mugear.: mugearite; benmor.: benmoreite. *: ages already given in Chauvel et al. (2012) but without details.

Table 2. Major and trace element ICP-AES analyses of dated lavas from Hiva Oa. Major element oxides in wt\%, trace elements in ppm. $\mathrm{Fe}_{2} \mathrm{O}_{3}{ }^{*}$ : total iron as $\mathrm{Fe}_{2} \mathrm{O}_{3}$. See text for analytical methods, Table 1 for ages and Fig. 4 for sample locations. Samples are ranked by order of decreasing ages. SH: shield; PS: postshield. Thol: tholeiite; haw: hawaiite; mug: mugearite; ben: benmoreite; tra: trachyte. The rare earth element and $\mathrm{Y}$ concentrations of sample HV54 have been modified by supergene alteration involving crystallization of rhabdophane (Cotten et al., 1995), and therefore this sample has not been plotted in Fig. 6. *: Major element analyses given in Chauvel et al. (2012) together with ICP-MS trace element analyses.

Table 3. Unspiked ${ }^{40} \mathrm{~K}-{ }^{40} \mathrm{Ar}$ ages measured on groundmass for Motane, Tahuata and Fatu Hiva lavas. See text for analytical methods and Fig. 4 for sample locations. SH: shield; PS: post-shield. Alk. bas.: alkali basalt. *: ages already given in Chauvel et al. (2012) but without details.

Table 4. Major and trace element ICP-AES analyses of dated lavas from Motane, Tahuata and Fatu Hiva. Major element oxides in wt\%, trace elements in ppm. $\mathrm{Fe}_{2} \mathrm{O}_{3}{ }^{*}$ : total iron as $\mathrm{Fe}_{2} \mathrm{O}_{3}$. See text for analytical methods, Table 3 for ages and Fig. 4 for sample locations. For each island, samples are ranked by order of decreasing ages. SH: shield; PS: post-shield. Thol: tholeiite; alb: alkali basalt; bas: basanite; haw: hawaiite; teph: tephriphonolite; tra: trachyte. *: Major element analyses given in Chauvel et al. (2012) together with ICP-MS trace element analyses. 
Click here to download Table: Table 1 Guillou et al.doc

\begin{tabular}{|c|c|c|c|c|c|c|c|}
\hline $\begin{array}{c}\text { Sample \& } \\
\text { Experiment }\end{array}$ & $\begin{array}{l}\text { Occurrence } \\
\text { \& Type }\end{array}$ & $\begin{array}{c}K(w t \%) \\
\pm 1 \sigma\end{array}$ & $\begin{array}{l}\text { Mass } \\
\text { molten } \\
(\mathrm{g})\end{array}$ & $\begin{array}{c}{ }^{40} \mathrm{Ar}^{*} \\
(\%)\end{array}$ & $\begin{array}{c}40 \mathrm{Ar}^{\star} \\
\left(10^{-12} \mathrm{~mol} . / \mathrm{g}\right) \\
\pm 1 \sigma\end{array}$ & $\begin{array}{c}\text { Weighted mean } \\
\begin{array}{c}40 \mathrm{Ar}^{*}\left(10^{-12} \mathrm{~mol} . / \mathrm{g}\right) \\
\pm 1 \sigma\end{array}\end{array}$ & $\begin{array}{l}\text { Age } \\
(\mathrm{Ma}) \\
\pm 2 \sigma\end{array}$ \\
\hline $\begin{array}{l}\text { HV107 } \\
7378\end{array}$ & $\begin{array}{l}\text { PS tholeiite } \\
\text { flow }\end{array}$ & $1.978 \pm 0.020$ & 1.43274 & 36.482 & $4.935 \pm 0.026$ & & \\
\hline 7394 & Ootua & « ........... » & 1.64660 & 49.561 & $4.925 \pm 0.025$ & $4.930 \pm 0.018$ & $1.44 \pm 0.03$ \\
\hline HV88 & SH hawaiite & & & & & & \\
\hline 7347 & upper flow & $1.695 \pm 0.017$ & 1.35898 & 47.011 & $4.273 \pm 0.022$ & & \\
\hline 7361 & Puamau & « $\ldots \ldots \ldots \ldots \ldots, »$ & 1.50413 & 60.993 & $4.311 \pm 0.022$ & $4.292 \pm 0.016$ & $1.46 \pm 0.03$ \\
\hline HV86 & PS hawaiite & & & & & & \\
\hline 7308 & flow & $1.501 \pm 0.015$ & 1.03777 & 20.778 & $4.077 \pm 0.023$ & & \\
\hline 7324 & Ootua & « $\ldots \ldots \ldots \ldots \ldots »$ & 1.69426 & 56.220 & $3.823 \pm 0.020$ & $3.932 \pm 0.015$ & $1.51 \pm 0.03$ \\
\hline HV62 & SH tholeiite & & & & & & \\
\hline 7323 & flow & $1.507 \pm 0.015$ & 1.21717 & 21.901 & $4.185 \pm 0.023$ & & \\
\hline 7339 & Puamau & « $\ldots \ldots \ldots \ldots .$, & 1.08625 & 33.020 & $4.300 \pm 0.023$ & $4.241 \pm 0.016$ & $1.62 \pm 0.04$ \\
\hline HV54 & PS benmor. & & & & & & \\
\hline 7548 & dyke & $2.638 \pm 0.026$ & 1.00103 & 55.652 & $7.369 \pm 0.037$ & & \\
\hline 7564 & Ootua & « $\ldots \ldots \ldots \ldots \ldots »$ & 2.07615 & 63.800 & $7.640 \pm 0.038$ & $7.500 \pm 0.027$ & $1.64 \pm 0.03$ \\
\hline HV70 & SH tholeiite & & & & & & \\
\hline 7302 & flow & $1.509 \pm 0.015$ & 1.06608 & 33.920 & $4.227 \pm 0.023$ & & \\
\hline 7316 & Puamau & $« \ldots \ldots \ldots \ldots ., »$ & 1.07234 & 19.444 & $4.418 \pm 0.025$ & $4.315 \pm 0.017$ & $1.65 \pm 0.04$ \\
\hline HV56 & PS mugear. & & & & & & \\
\hline 7541 & flow & $1.991 \pm 0.020$ & 1.13733 & 16.494 & $5.993 \pm 0.032$ & & \\
\hline 7557 & Ootua & $\langle\ldots \ldots \ldots \ldots\rangle$, & 1.17474 & 30.860 & $5.981 \pm 0.033$ & $5.987 \pm 0.023$ & $1.73 \pm 0.04$ \\
\hline HV65 & PS tholeiite & & & & & & \\
\hline 7293 & flow & $1.181 \pm 0.012$ & 1.16980 & 27.526 & $3.676 \pm 0.020$ & & \\
\hline 7309 & Atuona & « . ........... & 1.27950 & 21.735 & $3.715 \pm 0.020$ & $3.695 \pm 0.014$ & $1.80 \pm 0.04$ \\
\hline HV81 & SH hawaiite & & & & & & \\
\hline 7332 & flow & $1.976 \pm 0.020$ & 1.08717 & 18.778 & $6.232 \pm 0.033$ & & \\
\hline 7348 & Temetiu & $« \ldots \ldots \ldots \ldots .$, & 1.35792 & 17.642 & $6.316 \pm 0.033$ & $6.275 \pm 0.023$ & $1.83 \pm 0.04$ \\
\hline HV82 & SH tholeiite & & & & & & \\
\hline 7315 & flow & $1.137 \pm 0.011$ & 1.10367 & 19.184 & $3.821 \pm 0.022$ & & \\
\hline 7331 & Temetiu & $« \ldots \ldots \ldots \ldots, »$ & 1.27970 & 21.827 & $3.736 \pm 0.021$ & $3.777 \pm 0.015$ & $1.91 \pm 0.04$ \\
\hline HV99 & SH tholeiite & & & & & & \\
\hline 7472 & dyke & $1.869 \pm 0.020$ & 0.56437 & 36.823 & $6.539 \pm 0.033$ & & \\
\hline 7587 & Temetiu & « $\ldots \ldots \ldots \ldots ., »$ & 0.61803 & 6.398 & $6.525 \pm 0.033$ & $6.533 \pm 0.024$ & $2.01 \pm 0.04$ \\
\hline HV76* & SH tholeiite & & & & & & \\
\hline 7301 & flow & $1.254 \pm 0.013$ & 1.02679 & 29.743 & $4.477 \pm 0.025$ & & \\
\hline 7320 & Temetiu & $« \ldots \ldots \ldots \ldots .$, & 1.12163 & 24.685 & $4.338 \pm 0.024$ & $4.406 \pm 0.017$ & $2.02 \pm 0.04$ \\
\hline HV11 & $\mathrm{SH}$ tholeiite & & & & & & \\
\hline 7543 & flow & $1.459 \pm 0.015$ & 1.38244 & 33.999 & $5.325 \pm 0.027$ & & \\
\hline 7559 & Temetiu & $« \ldots \ldots \ldots \ldots, »$ & 1.26070 & 4.831 & $5.157 \pm 0.033$ & $5.258 \pm 0.021$ & $2.08 \pm 0.04$ \\
\hline HV38 & SH hawaiite & & & & & & \\
\hline 7549 & flow & $1.870 \pm 0.019$ & 0.93187 & 32.635 & $6.598 \pm 0.034$ & & \\
\hline 7565 & Temetiu & « $\ldots \ldots \ldots \ldots \ldots, »$ & 0.95534 & 22.934 & $6.904 \pm 0.036$ & $6.744 \pm 0.025$ & $2.08 \pm 0.04$ \\
\hline HV112 & SH hawaiite & & & & & & \\
\hline 7379 & flow & $1.824 \pm 0.018$ & 1.13791 & 42.865 & $6.701 \pm 0.035$ & & \\
\hline 7395 & Temetiu & « $\ldots \ldots \ldots \ldots \ldots »$ & 1.49233 & 23.887 & $6.762 \pm 0.035$ & $6.731 \pm 0.024$ & $2.13 \pm 0.05$ \\
\hline HV78 & SH tholeiite & & & & & & \\
\hline 7456 & flow & $1.322 \pm 0.013$ & 0.99687 & 25.760 & $4.916 \pm 0.026$ & & \\
\hline 7472 & Temetiu & $« \ldots \ldots \ldots \ldots\rangle$, & 1.50904 & 23.970 & $4.865 \pm 0.025$ & $4.890 \pm 0.018$ & $2.13 \pm 0.05$ \\
\hline HV77 & SH hawaiite & & & & & & \\
\hline 7325 & flow & $1.848 \pm 0.018$ & 1.39336 & 22.254 & $7.005 \pm 0.037$ & & \\
\hline 7340 & Temetiu & « ........... & 1.04261 & 35.918 & $6.934 \pm 0.036$ & $6.969 \pm 0.026$ & $2.17 \pm 0.05$ \\
\hline $\begin{array}{l}\text { HV84 } \\
7618\end{array}$ & $\begin{array}{l}\text { SH tholeiite } \\
\text { flow }\end{array}$ & $1.150 \pm 0.015$ & 1.03595 & 27.021 & $4.456 \pm 0.023$ & & \\
\hline 7634 & Temetiu & « $\ldots \ldots \ldots \ldots »$ & 1.56657 & 48.619 & $4.521 \pm 0.023$ & $4.489 \pm 0.016$ & $2.25 \pm 0.05$ \\
\hline
\end{tabular}




\begin{tabular}{lccccccc} 
HV87 & SH tholeiite & & & & & \\
7455 & flow & $1.403 \pm 0.014$ & 1.01446 & 32.032 & $5.532 \pm 0.029$ & & \\
7471 & Temetiu & $« \ldots \ldots \ldots \ldots »$ & 1.50142 & 24.886 & $5.505 \pm 0.028$ & $5.518 \pm 0.020$ & $2.27 \pm 0.05$ \\
& & & & & & & \\
HV64* & SH tholeiite & & & & & \\
7341 & flow & $0.913 \pm 0.009$ & 1.23639 & 24.869 & $4.046 \pm 0.022$ & & \\
7357 & Taaoa & $\ll \ldots \ldots \ldots \ldots »$ & 1.12964 & 25.818 & $4.036 \pm 0.022$ & $4.041 \pm 0.016$ & $2.55 \pm 0.05$ \\
\hline
\end{tabular}

* Age in Chauvel et al. (2012) but no details. 


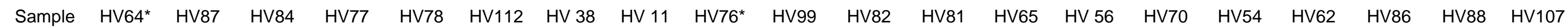
Volcano Taaoa Temetiu Temetiu Temetiu Temetiu Temetiu Temetiu Temetiu Temetiu Temetiu Temetiu Temetiu Atuona Ootua Puamau Ootua Puamau Ootua Puamau Ootua type SH thol SH thol SH thol SH haw SH thol SH haw SH haw SH thol SH thol SH thol SH thol SH haw PS thol PS mug SH thol PS ben SH thol PS haw SH haw PS thol

\begin{tabular}{|c|c|c|c|c|c|c|c|c|c|c|c|c|c|c|c|c|c|c|c|c|}
\hline $\mathrm{SiO} 2$ & 46.60 & 46.20 & 48.40 & 48.00 & 48.00 & 48.40 & 48.75 & 47.10 & 48.50 & 47.00 & 48.60 & 48.00 & 46.00 & 50.70 & 46.75 & 54.50 & 48.40 & 48.60 & 48.20 & 47.60 \\
\hline $\mathrm{TiO} 2$ & 3.55 & 3.26 & 3.34 & 3.52 & 3.22 & 3.71 & 3.72 & 3.61 & 3.84 & 2.99 & 3.78 & 3.67 & 3.65 & 3.12 & 4.05 & 2.17 & 3.01 & 3.92 & 3.69 & 2.85 \\
\hline $\mathrm{Al} 2 \mathrm{O} 3$ & 13.40 & 11.50 & 13.55 & 14.42 & 13.60 & 15.54 & 15.90 & 13.80 & 14.65 & 12.94 & 14.15 & 15.35 & 13.75 & 15.83 & 13.15 & 16.34 & 13.25 & 16.00 & 14.20 & 12.35 \\
\hline $\mathrm{Fe} 2 \mathrm{O}^{*}$ & 13.00 & 13.60 & 12.40 & 11.88 & 12.80 & 11.58 & 11.60 & 12.35 & 12.85 & 11.70 & 13.00 & 11.58 & 13.15 & 11.10 & 12.80 & 8.45 & 11.90 & 11.90 & 12.20 & 12.40 \\
\hline $\mathrm{MnO}$ & 0.15 & 0.17 & 0.15 & 0.16 & 0.17 & 0.18 & 0.15 & 0.16 & 0.15 & 0.15 & 0.16 & 0.15 & 0.16 & 0.17 & 0.16 & 0.18 & 0.14 & 0.19 & 0.16 & 0.16 \\
\hline $\mathrm{MgO}$ & 8.00 & 11.40 & 8.44 & 7.18 & 7.86 & 4.32 & 3.55 & 6.20 & 5.14 & 9.20 & 6.12 & 4.14 & 8.85 & 3.70 & 8.75 & 2.36 & 8.95 & 4.58 & 6.85 & 10.67 \\
\hline $\mathrm{CaO}$ & 9.00 & 8.30 & 8.56 & 8.60 & 9.75 & 9.07 & 8.00 & 9.75 & 9.63 & 7.95 & 9.00 & 8.60 & 10.28 & 7.50 & 9.40 & 5.52 & 8.40 & 9.25 & 8.58 & 8.90 \\
\hline $\mathrm{Na} 2 \mathrm{O}$ & 3.18 & 2.37 & 3.18 & 3.30 & 2.68 & 3.32 & 3.85 & 2.75 & 2.91 & 2.63 & 2.95 & 3.16 & 2.60 & 4.00 & 2.70 & 4.91 & 2.75 & 3.27 & 3.20 & 2.50 \\
\hline K2O & 1.08 & 1.22 & 1.33 & 2.08 & 1.18 & 2.08 & 2.26 & 1.69 & 1.49 & 1.94 & 1.23 & 2.27 & 1.45 & 2.42 & 1.63 & 3.19 & 1.69 & 1.77 & 1.94 & 1.70 \\
\hline P2O5 & 0.50 & 0.41 & 0.53 & 0.49 & 0.38 & 0.56 & 0.62 & 0.48 & 0.43 & 0.47 & 0.47 & 0.63 & 0.43 & 0.66 & 0.50 & 0.86 & 0.42 & 0.49 & 0.58 & 0.41 \\
\hline LOI & 1.29 & 0.86 & 0.22 & 0.19 & 0.43 & 0.87 & 1.07 & 1.56 & 0.32 & 2.77 & 0.32 & 1.90 & -0.39 & 0.61 & -0.05 & 1.33 & 0.61 & 0.28 & -0.08 & 0.08 \\
\hline Total & 99.75 & 99.29 & 99.92 & 99.44 & 100.07 & 99.63 & 99.47 & 99.45 & 99.91 & 99.74 & 99.78 & 99.45 & 99.93 & 99.81 & 99.84 & 99.81 & 99.52 & 100.25 & 99.52 & 99.62 \\
\hline $\mathrm{Rb}$ & 18.3 & 28.4 & 27.5 & 51.0 & 26.5 & 62.0 & 53.5 & 42.5 & 51.5 & 48.0 & 17.6 & 62.0 & 34.0 & 61.0 & 36.5 & 80.0 & 35.0 & 42.5 & 50.0 & 42.0 \\
\hline $\mathrm{Ba}$ & 217 & 238 & 282 & 410 & 224 & 412 & 404 & 334 & 278 & 350 & 325 & 465 & 295 & 485 & 345 & 730 & 295 & 375 & 385 & 332 \\
\hline Th & 3.85 & 3.55 & 4.90 & 5.90 & 2.90 & 5.80 & 6.10 & 4.60 & 3.20 & 4.90 & 4.10 & 5.40 & 3.30 & 6.20 & 3.75 & 7.60 & 3.50 & 3.90 & 5.15 & 3.65 \\
\hline $\mathrm{Nb}$ & 41.0 & 34.0 & 43.0 & 44.0 & 29.5 & 43.0 & 49.0 & 38.5 & 31.0 & 36.0 & 35.0 & 47.5 & 33.5 & 48.0 & 39.0 & 63.0 & 30.5 & 36.0 & 44.5 & 32.0 \\
\hline $\mathrm{La}$ & 33.0 & 30.5 & 38.0 & 40.5 & 25.0 & 42.0 & 44.0 & 37.0 & 30.5 & 35.5 & 33.0 & 47.5 & 28.0 & 47.0 & 32.0 & 78.0 & 28.0 & 38.0 & 39.5 & 31.0 \\
\hline $\mathrm{Ce}$ & 72.0 & 66.0 & 83.0 & 86.0 & 57.0 & 88.0 & 98.0 & 81.0 & 65.5 & 77.0 & 68.5 & 100 & 61.5 & 102 & 73.0 & 154.0 & 60.0 & 99.0 & 88.0 & 63.0 \\
\hline $\mathrm{Sr}$ & 599 & 435 & 650 & 682 & 485 & 670 & 660 & 570 & 586 & 479 & 482 & 746 & 637 & 668 & 635 & 780 & 473 & 625 & 626 & 510 \\
\hline $\mathrm{Nd}$ & 42.0 & 36.0 & 45.0 & 43.0 & 33.0 & 47.0 & 55.0 & 45.0 & 40.0 & 40.5 & 44.5 & 52.0 & 34.0 & 56.0 & 43.0 & 98.0 & 36.0 & 61.0 & 48.0 & 35.5 \\
\hline Sm & 9.40 & 8.15 & 9.90 & 8.75 & 7.60 & 10.1 & 11.0 & 9.45 & 9.05 & 8.75 & 10.0 & 10.6 & 7.70 & 11.5 & 9.35 & 20.0 & 8.15 & 15.9 & 10.2 & 7.85 \\
\hline $\mathrm{Zr}$ & 315 & 262 & 352 & 322 & 245 & 342 & 400 & 292 & 278 & 315 & 305 & 375 & 240 & 375 & 315 & 510 & 260 & 297 & 376 & 249 \\
\hline $\mathrm{Eu}$ & 2.97 & 2.53 & 3.05 & 2.66 & 2.38 & 2.98 & 3.43 & 2.80 & 2.77 & 2.60 & 3.13 & 3.16 & 2.40 & 3.46 & 2.87 & 5.80 & 2.48 & 5.74 & 3.17 & 2.32 \\
\hline $\mathrm{Gd}$ & 8.60 & 7.70 & 8.10 & 7.90 & 7.10 & 9.00 & 10.7 & 9.15 & 8.30 & 7.80 & 9.55 & 9.05 & 6.80 & 11.1 & 9.20 & 21.50 & 7.50 & 23.70 & 9.45 & 7.20 \\
\hline Dy & 6.65 & 6.15 & 6.30 & 6.20 & 6.10 & 7.20 & 8.10 & 7.00 & 7.20 & 6.15 & 8.40 & 7.40 & 5.55 & 8.70 & 6.90 & 18.40 & 6.05 & 24.00 & 7.55 & 5.80 \\
\hline Y & 32.5 & 31.0 & 30.0 & 31.5 & 31.0 & 36.0 & 41.0 & 34.5 & 35.5 & 30.0 & 43.0 & 38.5 & 27.5 & 46.0 & 33.0 & 116.0 & 31.5 & 21.0 & 38.0 & 29.0 \\
\hline Er & 2.80 & 2.60 & 2.40 & 2.60 & 2.60 & 3.00 & 3.60 & 3.10 & 3.00 & 2.60 & 3.50 & 3.20 & 2.20 & 4.00 & 2.90 & 9.40 & 2.60 & 14.50 & 3.20 & 2.50 \\
\hline $\mathrm{Yb}$ & 2.16 & 2.19 & 1.92 & 2.10 & 2.14 & 2.50 & 2.72 & 2.35 & 2.54 & 2.07 & 3.01 & 2.69 & 1.86 & 3.10 & 2.09 & 7.16 & 2.22 & 13.70 & 2.60 & 2.02 \\
\hline Sc & 23.0 & 23.0 & 19.5 & 21.0 & 25.5 & 19. & 18.5 & 24.0 & 24.0 & 21.5 & 23.0 & 19.3 & 25.0 & 15.0 & 23.0 & 9.5 & 23.0 & 22.0 & 19.5 & 22.5 \\
\hline V & 300 & 286 & 265 & 295 & 300 & 328 & 314 & 332 & 341 & 256 & 348 & 329 & 352 & 290 & 325 & 128 & 284 & 337 & 314 & 270 \\
\hline $\mathrm{Cr}$ & 428 & 386 & 335 & 258 & 326 & 49.0 & 10.0 & 201 & 69.0 & 365 & 191 & 17.0 & 357 & 7.00 & 301 & 2 & 432 & 55 & 207 & 410 \\
\hline Co & 52.0 & 64.0 & 52.0 & 43.0 & 51.0 & 44.0 & 31.0 & 40.0 & 39.0 & 47.0 & 40.0 & 32.0 & 53.0 & 26.0 & 51.0 & 8.0 & 48.0 & 37.0 & 41.0 & 54.0 \\
\hline $\mathrm{Ni}$ & 272 & 404 & 252 & 165 & 226 & 88.0 & 39.0 & 98.0 & 71.0 & 215 & 155 & 53.0 & 205 & 7.00 & 240 & 1 & 280 & 50 & 164 & 320 \\
\hline Q & 0.00 & 0.00 & 0.00 & 0.00 & 1.61 & 1.15 & 0.52 & 1.24 & 3.64 & 0.00 & 3.94 & 1.90 & 0.00 & 1.65 & 0.00 & 2.68 & 0.12 & 1.63 & 0.00 & 0.00 \\
\hline ne & 0.00 & 0.00 & 0.00 & 0.00 & 0.00 & 0.00 & 0.00 & 0.00 & 0.00 & 0.00 & 0.00 & 0.00 & 0.00 & 0.00 & 0.00 & 0.00 & 0.00 & 0.00 & 0.00 & 0.00 \\
\hline hy & 12.74 & 20.32 & 16.89 & 6.62 & 14.62 & 7.96 & 7.45 & 10.76 & 9.31 & 15.98 & 12.61 & 8.38 & 7.01 & 7.55 & 12.19 & 5.23 & 18.62 & 9.23 & 12.70 & 14.32 \\
\hline ol & 2.38 & 2.96 & 0.57 & 5.51 & 0.00 & 0.00 & 0.00 & 0.00 & 0.00 & 2.64 & 0.00 & 0.00 & 6.86 & 0.00 & 3.97 & 0.00 & 0.00 & 0.00 & 1.06 & 4.87 \\
\hline
\end{tabular}

* In Chauvel et al., 2012 
Click here to download Table: Table 3 Guillou et al.doc

\begin{tabular}{|c|c|c|c|c|c|c|c|}
\hline $\begin{array}{c}\text { Sample \& } \\
\text { Experiment }\end{array}$ & $\begin{array}{l}\text { Occurrence } \\
\text { \& Type }\end{array}$ & $\begin{array}{c}\mathrm{K}(\mathrm{wt} \%) \\
\pm 1 \sigma\end{array}$ & $\begin{array}{l}\text { Mass } \\
\text { molten } \\
(\mathrm{g})\end{array}$ & $\begin{array}{l}{ }^{40} \mathrm{Ar}^{*} \\
(\%)\end{array}$ & $\begin{array}{c}40 \mathrm{Ar}^{*} \\
\left(10^{-12} \mathrm{~mol} . / \mathrm{g}\right) \\
\pm 1 \sigma\end{array}$ & $\begin{array}{c}\text { Weighted mean } \\
40 \mathrm{Ar}^{\star}\left(10^{-12} \mathrm{~mol} . / \mathrm{g}\right) \\
\pm 1 \sigma\end{array}$ & $\begin{array}{l}\text { Age } \\
(\mathrm{Ma}) \\
\pm 2 \sigma\end{array}$ \\
\hline $\begin{array}{l}\text { MT04 }^{*} \\
8026 \\
8042\end{array}$ & $\begin{array}{l}\text { SH tholeiite } \\
\text { flow } \\
\text { Motane }\end{array}$ & $\begin{array}{l}0.656 \pm 0.007 \\
« \ldots \ldots \ldots . »\end{array}$ & $\begin{array}{l}1.00089 \\
1.00253\end{array}$ & $\begin{array}{l}9.104 \\
5.592\end{array}$ & $\begin{array}{l}1.794 \pm 0.013 \\
1.825 \pm 0.014\end{array}$ & $1.808 \pm 0.010$ & $1.59 \pm 0.04$ \\
\hline $\begin{array}{c}\text { MT08* }^{*} \\
8027 \\
8043\end{array}$ & $\begin{array}{l}\text { SH tholeiite } \\
\text { flow } \\
\text { Motane }\end{array}$ & $\begin{array}{c}1.112 \pm 0.011 \\
« \ldots \ldots \ldots \ldots \ldots\end{array}$ & $\begin{array}{l}1.02209 \\
2.00172\end{array}$ & $\begin{array}{l}39.698 \\
33.989\end{array}$ & $\begin{array}{l}2.978 \pm 0.018 \\
2.943 \pm 0.015\end{array}$ & $2.958 \pm 0.012$ & $1.53 \pm 0.03$ \\
\hline $\begin{array}{l}\text { MT11 } \\
8028 \\
8044\end{array}$ & $\begin{array}{l}\text { SH alk. bas. } \\
\text { dyke } \\
\text { Motane }\end{array}$ & $\begin{array}{c}1.685 \pm 0.017 \\
« \ldots \ldots \ldots \ldots . .\end{array}$ & $\begin{array}{l}1.00579 \\
1.00148\end{array}$ & $\begin{array}{l}28.565 \\
20.518\end{array}$ & $\begin{array}{l}5.733 \pm 0.029 \\
5.745 \pm 0.030\end{array}$ & $5.739 \pm 0.021$ & $1.96 \pm 0.04$ \\
\hline $\begin{array}{l}\text { TH8* } \\
8052 \\
8067\end{array}$ & $\begin{array}{c}P S \text { hawaiite } \\
\text { flow } \\
\text { Hanatetena }\end{array}$ & $\begin{array}{c}1.563 \pm 0.015 \\
« \ldots \ldots \ldots \ldots \ldots\end{array}$ & $\begin{array}{l}1.00087 \\
1.50091\end{array}$ & $\begin{array}{l}36.879 \\
47.536\end{array}$ & $\begin{array}{l}4.712 \pm 0.025 \\
4.744 \pm 0.024\end{array}$ & $4.728 \pm 0.017$ & $1.74 \pm 0.04$ \\
\hline $\begin{array}{l}\text { TH35 } \\
7796 \\
7812\end{array}$ & $\begin{array}{l}\text { PS tephriph. } \\
\text { needle } \\
\text { Vaitahu }\end{array}$ & 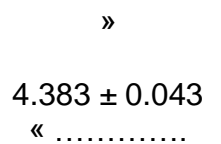 & $\begin{array}{l}0.49301 \\
0.98675\end{array}$ & $\begin{array}{l}45.584 \\
43.218\end{array}$ & $\begin{array}{l}13.219 \pm 0.068 \\
13.527 \pm 0.069\end{array}$ & $13.523+0.048$ & $1.78+0.04$ \\
\hline $\begin{array}{l}\text { TH31* } \\
7794 \\
7810\end{array}$ & $\begin{array}{l}\text { PS tholeiite } \\
\text { flow } \\
\text { Hanatetena }\end{array}$ & $\begin{array}{c}» \\
0.631 \pm 0.006 \\
« \ldots \ldots \ldots \ldots \ldots .\end{array}$ & $\begin{array}{l}1.18672 \\
1.23815\end{array}$ & $\begin{array}{c}14.510 \\
6.891\end{array}$ & $\begin{array}{l}2.015 \pm 0.013 \\
1.908 \pm 0.015\end{array}$ & $1.966 \pm 0.010$ & $1.80 \pm 0.04$ \\
\hline $\begin{array}{l}\text { TH14* }^{*} \\
8080 \\
8109\end{array}$ & $\begin{array}{l}\text { SH alk. bas. } \\
\text { flow } \\
\text { Vaitahu }\end{array}$ & $\begin{array}{c}" \\
0.847 \pm 0.009 \\
« \ldots \ldots \ldots \ldots \ldots\end{array}$ & $\begin{array}{l}1.00344 \\
1.00670\end{array}$ & $\begin{array}{l}15.206 \\
19.159\end{array}$ & $\begin{array}{l}2.668 \pm 0.016 \\
2.648 \pm 0.016\end{array}$ & $2.658 \pm 0.011$ & $1.81 \pm 0.04$ \\
\hline $\begin{array}{l}\text { TH18* } \\
8068 \\
8084\end{array}$ & $\begin{array}{l}\mathrm{SH} \text { tholeiite } \\
\text { flow } \\
\text { Vaitahu }\end{array}$ & $\begin{array}{c}" \\
1.303 \pm 0.013 \\
« \ldots \ldots \ldots \ldots . .\end{array}$ & $\begin{array}{l}1.03076 \\
1.00141\end{array}$ & $\begin{array}{l}21.981 \\
30.848\end{array}$ & $\begin{array}{l}4.111 \pm 0.022 \\
4.107 \pm 0.021\end{array}$ & $4.109 \pm 0.015$ & $1.82 \pm 0.04$ \\
\hline $\begin{array}{l}\text { TH13* }^{*} \\
8069 \\
8085\end{array}$ & $\begin{array}{l}\text { SH tholeiite } \\
\text { upper flow } \\
\text { Vaitahu }\end{array}$ & $\begin{array}{c}» \\
0.852 \pm 0.009 \\
« \ldots \ldots \ldots \ldots \ldots\end{array}$ & $\begin{array}{l}1.00095 \\
1.00289\end{array}$ & $\begin{array}{l}17.817 \\
16.538\end{array}$ & $\begin{array}{l}2.775 \pm 0.011 \\
2.783 \pm 0.016\end{array}$ & $2.779 \pm 0.011$ & $1.88 \pm 0.04$ \\
\hline $\begin{array}{l}\text { TH38 } \\
7899 \\
7915\end{array}$ & $\begin{array}{c}\text { SH tholeiite } \\
\text { flow } \\
\text { Vaitahu }\end{array}$ & $\begin{array}{l}1.195 \pm 0.012 \\
« \ldots \ldots \ldots \ldots \ldots\end{array}$ & $\begin{array}{l}1.09784 \\
1.59724\end{array}$ & $\begin{array}{l}41.032 \\
16.812\end{array}$ & $\begin{array}{l}3.849 \pm 0.029 \\
3.999 \pm 0.022\end{array}$ & $3.944 \pm 0.017$ & $1.90 \pm 0.04$ \\
\hline $\begin{array}{l}\text { TH37 } \\
7795 \\
7811\end{array}$ & $\begin{array}{c}\text { SH hawaiite } \\
\text { flow } \\
\text { Vaitahu }\end{array}$ & $\begin{array}{l}1.959 \pm 0.020 \\
« \ldots \ldots \ldots \ldots \ldots\end{array}$ & $\begin{array}{l}1.10225 \\
1.01065\end{array}$ & $\begin{array}{l}27.170 \\
20.584\end{array}$ & $\begin{array}{l}6.435 \pm 0.034 \\
6.546 \pm 0.036\end{array}$ & $6.487 \pm 0.025$ & $1.91 \pm 0.04$ \\
\hline $\begin{array}{l}\text { TH41 } \\
7910 \\
7926\end{array}$ & $\begin{array}{l}\text { SH tholeiite } \\
\text { flow } \\
\text { Vaitahu }\end{array}$ & $\begin{array}{l}0.407 \pm 0.004 \\
« \ldots \ldots \ldots \ldots \ldots\end{array}$ & $\begin{array}{l}1.05413 \\
1.1609\end{array}$ & $\begin{array}{l}11.485 \\
11.309\end{array}$ & $\begin{array}{l}1.419 \pm 0.011 \\
1.499 \pm 0.012\end{array}$ & $1.456 \pm 0.008$ & $2.06 \pm 0.05$ \\
\hline $\begin{array}{l}\text { TH39* } \\
7907 \\
7923\end{array}$ & $\begin{array}{l}\text { SH tholeiite } \\
\text { flow } \\
\text { Vaitahu }\end{array}$ & $\begin{array}{l}1.212 \pm 0.012 \\
« \ldots \ldots \ldots \ldots \ldots\end{array}$ & $\begin{array}{l}0.93740 \\
1.72916\end{array}$ & $\begin{array}{l}33.084 \\
25.158\end{array}$ & $\begin{array}{l}4.448 \pm 0.025 \\
4.418 \pm 0.023\end{array}$ & $4.432 \pm 0.017$ & $2.11 \pm 0.05$ \\
\hline $\begin{array}{l}\text { FH16 } \\
7928 \\
7944\end{array}$ & $\begin{array}{l}\text { PS trachyte } \\
\text { dome } \\
\text { Touaouoho }\end{array}$ & $\begin{array}{c}4.043 \pm 0.040 \\
« \ldots \ldots \ldots \ldots \ldots\end{array}$ & $\begin{array}{l}0.44685 \\
0.60293\end{array}$ & $\begin{array}{l}24.759 \\
70.794\end{array}$ & $\begin{array}{l}7.845 \pm 0.048 \\
7.782 \pm 0.041\end{array}$ & $7.809 \pm 0.031$ & $1.11 \pm 0.02$ \\
\hline $\begin{array}{l}\text { FH06 } \\
7918 \\
7932\end{array}$ & $\begin{array}{l}\text { PS trachyte } \\
\text { dome } \\
\text { Omoa }\end{array}$ & $\begin{array}{c}3.719 \pm 0.037 \\
« \ldots \ldots \ldots \ldots . .\end{array}$ & $\begin{array}{l}0.51412 \\
0.48218\end{array}$ & $\begin{array}{l}17.011 \\
25.537\end{array}$ & $\begin{array}{l}7.792 \pm 0.051 \\
7.886 \pm 0.044\end{array}$ & $7.845 \pm 0.032$ & $1.22 \pm 0.03$ \\
\hline $\begin{array}{l}\text { FH05 } \\
7938 \\
7954\end{array}$ & $\begin{array}{l}\text { PS tholeiite } \\
\text { flow } \\
\text { Omoa }\end{array}$ & $\begin{array}{c}0.672 \pm 0.007 \\
« \ldots \ldots \ldots \ldots . .\end{array}$ & $\begin{array}{l}0.44551 \\
0.55791\end{array}$ & $\begin{array}{l}5.529 \\
3.267\end{array}$ & $\begin{array}{l}1.437 \pm 0.023 \\
1.441 \pm 0.018\end{array}$ & $1.440 \pm 0.014$ & $1.23 \pm 0.04$ \\
\hline $\begin{array}{l}\text { FH11* } \\
7908 \\
7924\end{array}$ & $\begin{array}{l}\text { PS tholeiite } \\
\text { flow } \\
\text { Omoa }\end{array}$ & $\begin{array}{c}0.988 \pm 0.010 \\
« \ldots \ldots \ldots \ldots . .\end{array}$ & $\begin{array}{l}1.30538 \\
1.18210\end{array}$ & $\begin{array}{c}7.853 \\
27.261\end{array}$ & $\begin{array}{l}2.155 \pm 0.017 \\
2.157 \pm 0.013\end{array}$ & $2.156 \pm 0.010$ & $1.26 \pm 0.03$ \\
\hline $\begin{array}{c}\text { FH18* }^{*} \\
7917\end{array}$ & $\begin{array}{l}\mathrm{SH} \text { tholeiite } \\
\text { flow }\end{array}$ & $1.029 \pm 0.010$ & 1.16847 & 20.673 & $2.468 \pm 0.017$ & & \\
\hline
\end{tabular}




\begin{tabular}{|c|c|c|c|c|c|c|c|}
\hline 7933 & Touaouoho & « $\ldots \ldots \ldots \ldots \ldots\rangle$ & 1.0733 & 25.176 & $2.378 \pm 0.014$ & $2.416 \pm 0.011$ & $1.35 \pm 0.03$ \\
\hline $\begin{array}{l}\text { FH12 } \\
7960\end{array}$ & $\begin{array}{l}\text { PS trachyte } \\
\text { dyke }\end{array}$ & $3.238 \pm 0.033$ & 0.59089 & 23.677 & $7.859 \pm 0.043$ & & \\
\hline 7968 & Omoa & « $\ldots \ldots \ldots \ldots .$, & 0.51453 & 40.616 & $7.662 \pm 0.042$ & $7.557 \pm 0.030$ & $1.38 \pm 0.03$ \\
\hline $\mathrm{FHO1}^{*}$ & PS tholeiite & & & & & & \\
\hline 7805 & flow & $1.146 \pm 0.011$ & 1.17441 & 18.578 & $2.747 \pm 0.016$ & & \\
\hline 7821 & Omoa & $« \ldots \ldots \ldots \ldots$. & 1.63045 & 25.899 & $2.687 \pm 0.016$ & $2.718 \pm 0.011$ & $1.37 \pm 0.03$ \\
\hline FH30 & PS tholeiite & & & & & & \\
\hline 8157 & dyke & $1.021 \pm 0.010$ & 1.05080 & 12.193 & $2.515 \pm 0.015$ & & \\
\hline 8173 & Omoa & $\langle\ldots \ldots \ldots \ldots$ & 1.01932 & 5.904 & $2.459 \pm 0.018$ & $2.491 \pm 0.011$ & $1.41 \pm 0.03$ \\
\hline FH08 & SH tholeiite & & & & & & \\
\hline $\begin{array}{l}7806 \\
7822\end{array}$ & $\begin{array}{l}\text { flow } \\
\text { Omoa }\end{array}$ & $\begin{array}{c}0.755 \pm 0.008 \\
« \ldots \ldots \ldots \ldots »\end{array}$ & $\begin{array}{l}1.19866 \\
1.09248\end{array}$ & $\begin{array}{l}10.197 \\
11.745\end{array}$ & $\begin{array}{l}1.900 \pm 0.014 \\
1.838 \pm 0.015\end{array}$ & $1.869 \pm 0.010$ & $1.43 \pm 0.03$ \\
\hline FH19 & SH tholeiite & & & & & & \\
\hline 7909 & flow & $1.254 \pm 0.012$ & 1.14484 & 12.529 & $3.128 \pm 0.021$ & & \\
\hline 7925 & Touaouoho & « ............ & 1.20202 & 20.824 & $3.127 \pm 0.019$ & $3.127 \pm 0.013$ & $1.44 \pm 0.03$ \\
\hline FH17* & SH tholeiite & & & & & & \\
\hline 7802 & flow & $1.187 \pm 0.012$ & 1.32097 & 21.118 & $3.105 \pm 0.017$ & & \\
\hline 7818 & Touaouoho & « $\ldots \ldots \ldots \ldots, \mid$ & 1.42923 & 11.183 & $3.001 \pm 0.021$ & $3.064 \pm 0.013$ & $1.49 \pm 0.03$ \\
\hline $\begin{array}{l}\text { FH13* }^{*} \\
7801\end{array}$ & $\begin{array}{l}\text { SH tholeiite } \\
\text { flow }\end{array}$ & $1.229 \pm 0.012$ & 1.22071 & 27.683 & $3.833 \pm 0.021$ & & \\
\hline 7817 & Touaouoho & « ............ & 1.51566 & 4.430 & $3.920 \pm 0.032$ & $3.825 \pm 0.017$ & $1.81 \pm 0.04$ \\
\hline
\end{tabular}

* age in Chauvel et al. (2012) but no details 
Table

Click here to download Table: Table 4 Guillou et al.xls

\begin{tabular}{|c|c|c|c|c|c|c|c|c|c|c|}
\hline Sample & MT11 & MT04* $^{*}$ & MT08* & TH39* & TH41 & TH37 & TH38 & $\mathrm{TH}_{13}{ }^{*}$ & TH18* & $\mathrm{TH} 14^{*}$ \\
\hline Volcano & Motane & Motane & Motane & Vaitahu & Vaitahu & Vaitahu & Vaitahu & Vaitahu & Vaitahu & Vaitahu \\
\hline Type & $\mathrm{SH}$ alb & $\mathrm{SH}$ thol & $\mathrm{SH}$ thol & $\mathrm{SH}$ thol & $\mathrm{SH}$ thol & SH haw & $\mathrm{SH}$ thol & $\mathrm{SH}$ thol & $\mathrm{SH}$ thol & $\mathrm{SH}$ alb \\
\hline $\mathrm{SiO} 2$ & 44.10 & 47.90 & 47.90 & 47.20 & 45.80 & 47.00 & 46.70 & 47.70 & 47.70 & 46.40 \\
\hline TiO2 & 3.78 & 4.28 & 3.78 & 3.45 & 4.26 & 3.56 & 3.34 & 4.15 & 3.44 & 3.17 \\
\hline $\mathrm{Al} 2 \mathrm{O} 3$ & 13.75 & 14.65 & 14.86 & 12.70 & 14.70 & 16.10 & 11.90 & 14.70 & 14.60 & 13.17 \\
\hline $\mathrm{Fe} 2 \mathrm{O}^{*}$ & 12.90 & 12.93 & 12.32 & 12.80 & 13.30 & 12.40 & 12.80 & 12.35 & 12.30 & 12.66 \\
\hline $\mathrm{MnO}$ & 0.17 & 0.16 & 0.17 & 0.17 & 0.17 & 0.17 & 0.17 & 0.16 & 0.16 & 0.17 \\
\hline $\mathrm{MgO}$ & 5.96 & 5.63 & 5.53 & 9.20 & 6.20 & 5.10 & 11.00 & 6.09 & 6.40 & 8.37 \\
\hline $\mathrm{CaO}$ & 11.42 & 9.87 & 10.15 & 9.80 & 10.70 & 10.10 & 10.70 & 9.95 & 9.93 & 9.96 \\
\hline $\mathrm{Na} 2 \mathrm{O}$ & 2.55 & 3.05 & 3.13 & 2.70 & 2.30 & 3.20 & 2.30 & 3.09 & 2.99 & 3.36 \\
\hline K2O & 1.93 & 0.72 & 1.27 & 1.30 & 0.44 & 2.21 & 1.28 & 0.91 & 1.55 & 0.97 \\
\hline P2O5 & 0.63 & 0.50 & 0.52 & 0.52 & 0.52 & 0.60 & 0.43 & 0.51 & 0.46 & 0.48 \\
\hline LOI & 2.53 & 0.01 & 0.00 & 0.40 & 1.20 & 0.50 & 0.00 & -0.06 & 0.28 & 1.10 \\
\hline Total & 99.72 & 99.70 & 99.63 & 100.24 & 99.59 & 100.94 & 100.62 & 99.67 & 99.81 & 99.81 \\
\hline $\mathrm{Rb}$ & 51.0 & 11.2 & 26.0 & 32.2 & 4.9 & 64.2 & 25.1 & 11.7 & 40.5 & 9.3 \\
\hline $\mathrm{Ba}$ & 508 & 215 & 507 & 297 & 226 & 577 & 314 & 240 & 342 & 516 \\
\hline Th & 7.40 & 3.10 & 4.20 & 4.71 & 3.50 & 7.44 & 4.28 & 4.30 & 4.60 & 6.9 \\
\hline $\mathrm{Nb}$ & 54.5 & 38.4 & 39.0 & 41.1 & 38.3 & 50.9 & 37.5 & 44.0 & 42.0 & 50 \\
\hline La & 53.0 & 32.0 & 35.0 & 39.5 & 31.4 & 54.7 & 34.3 & 36.0 & 38.0 & 49 \\
\hline $\mathrm{Ce}$ & 108 & 71.0 & 76.0 & 84.6 & 72.3 & 112 & 75.9 & 77.0 & 78 & 96 \\
\hline Sr & 822 & 577 & 609 & 574 & 539 & 773 & 552 & 612 & 570 & 618 \\
\hline $\mathrm{Nd}$ & 55.0 & 42.5 & 45.0 & 45.6 & 42.3 & 49.9 & 38.2 & 44.0 & 41.5 & 45 \\
\hline Sm & 11.0 & 10.0 & 10.0 & 9.79 & 9.92 & 9.58 & 8.15 & 10.05 & 9.0 & 8.85 \\
\hline $\mathrm{Zr}$ & 358 & 335 & 310 & 279 & 308 & 323 & 250 & 347 & 280 & 295 \\
\hline
\end{tabular}




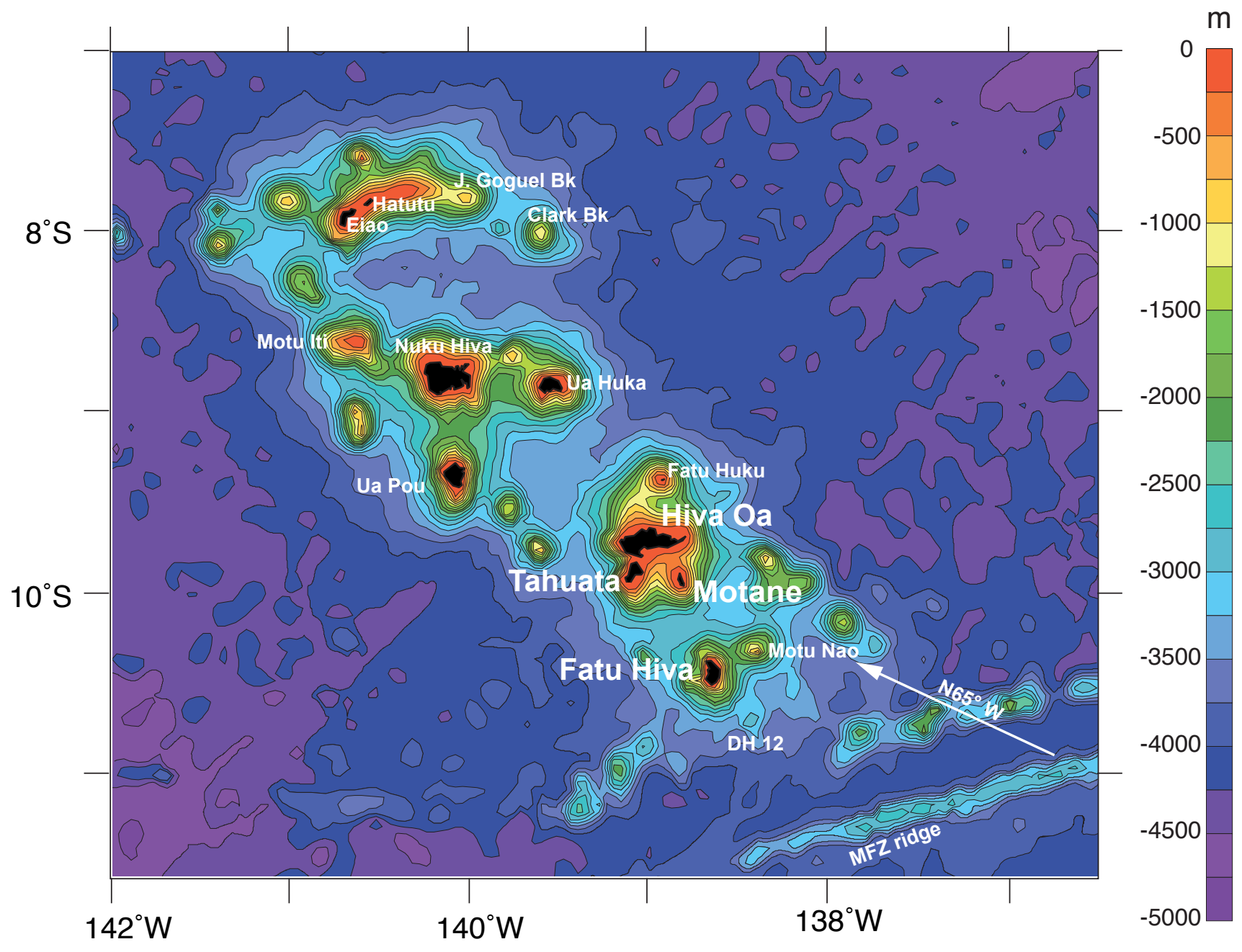









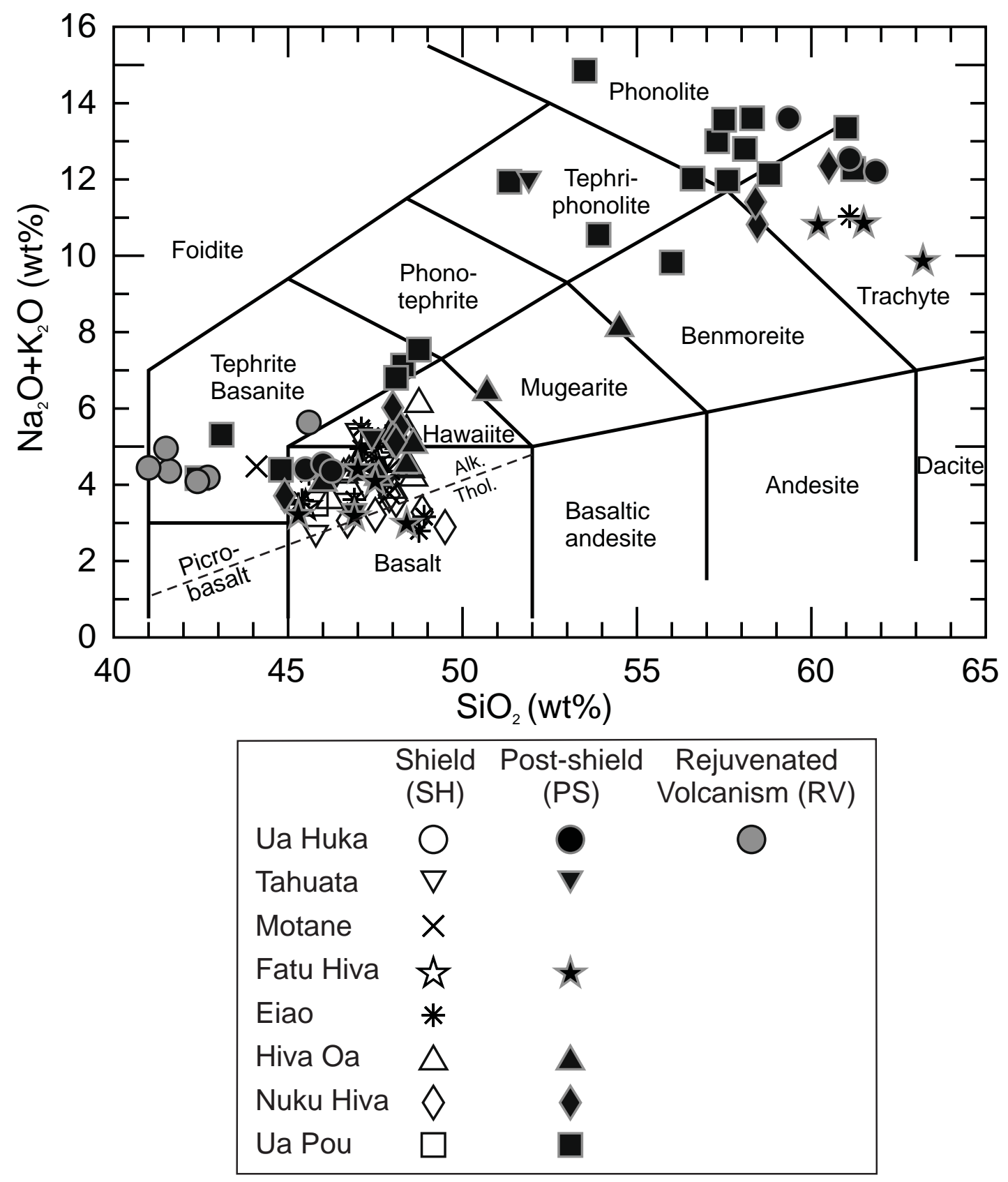


Eiao

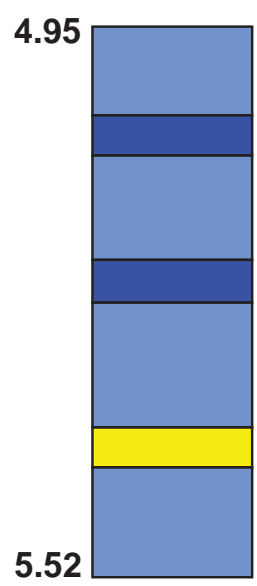

Hiva Oa
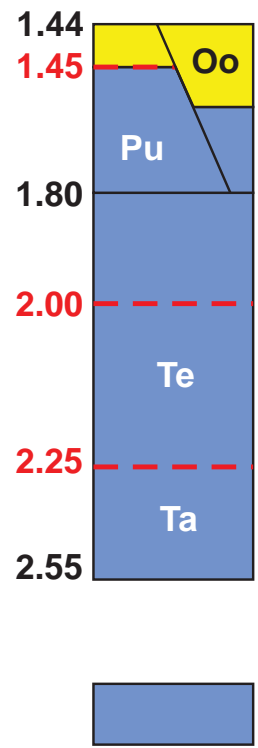

Tholeiitic basalts
Nuku Hiva

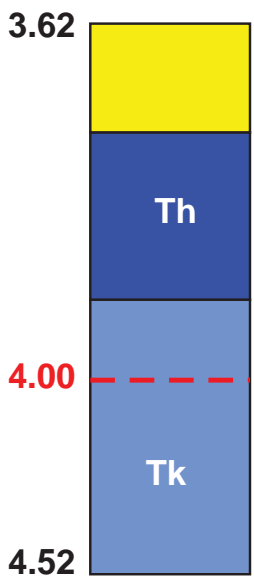

Motane


Alkali basalts \& basanites
Ua Huka

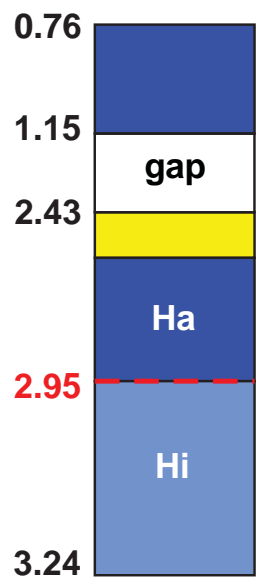

Tahuata

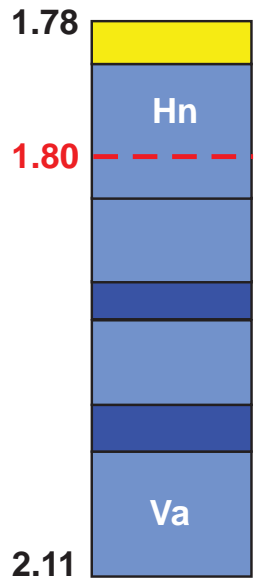

To

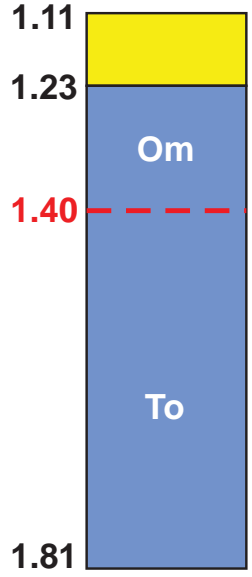

$4.00----$

Caldera collapse

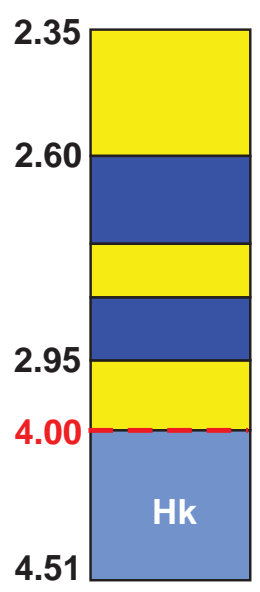

Fatu Hiva

Trachytes \& phonolites 


\section{Figure}

Click hè̈re to download Figure
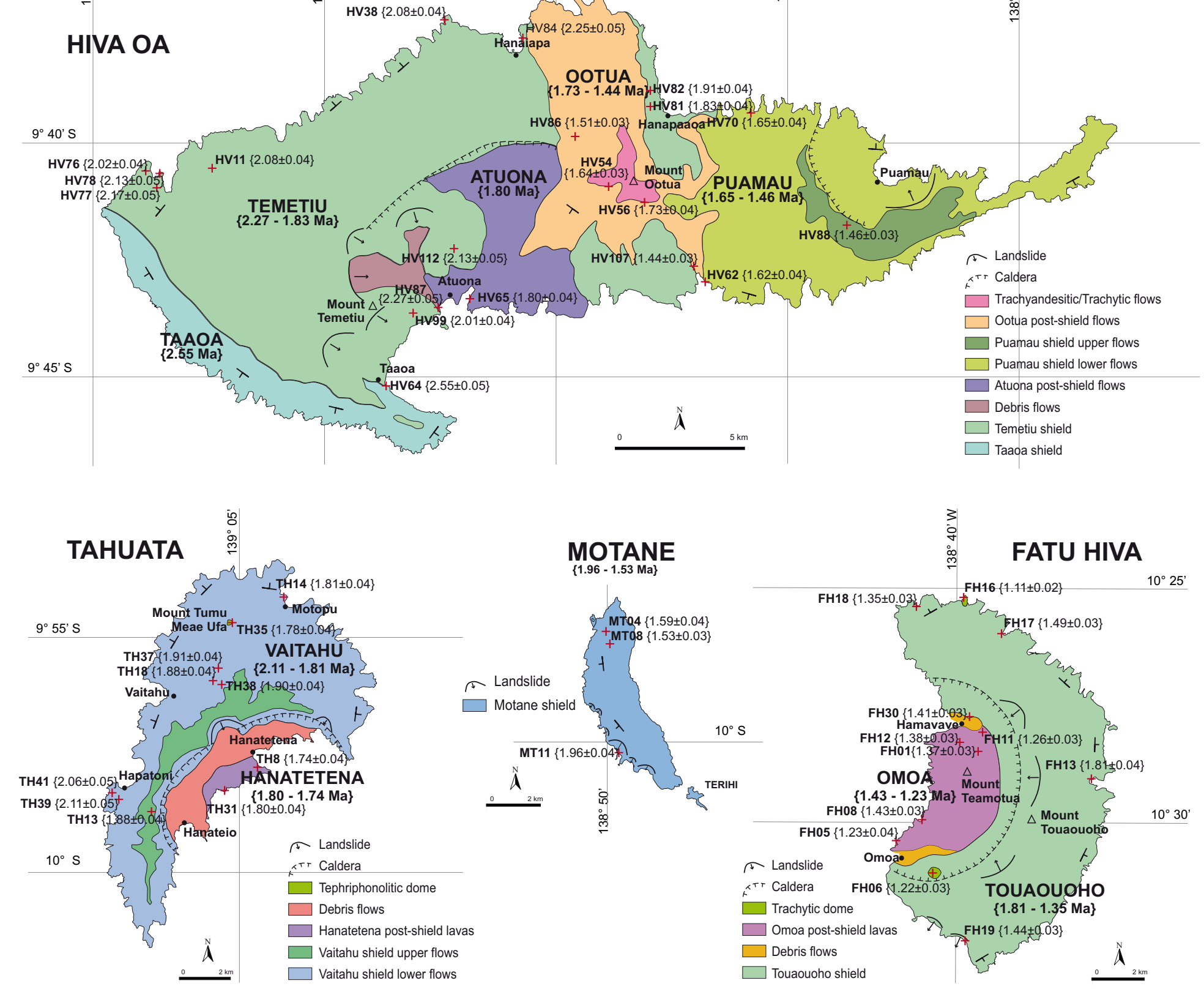







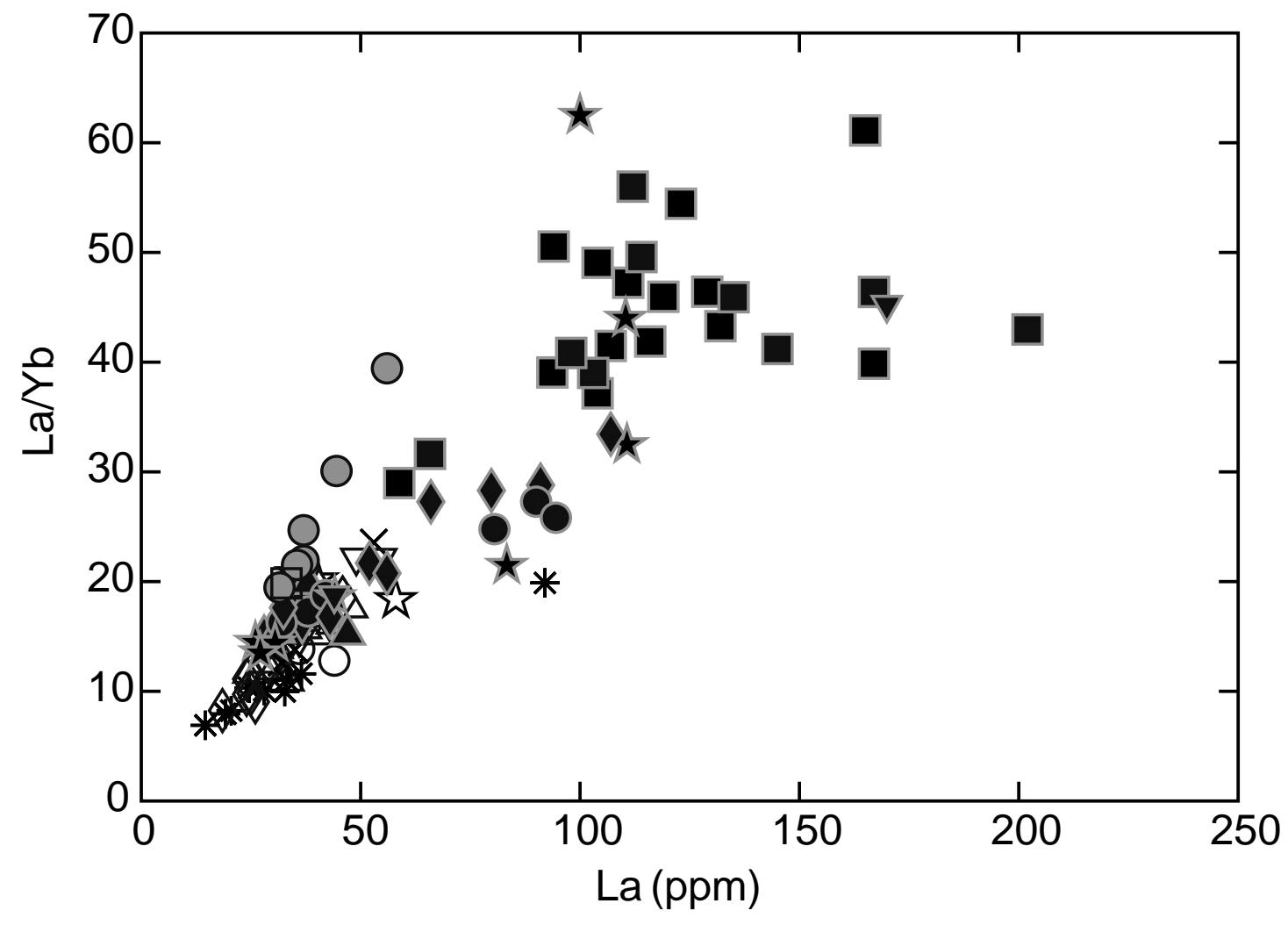




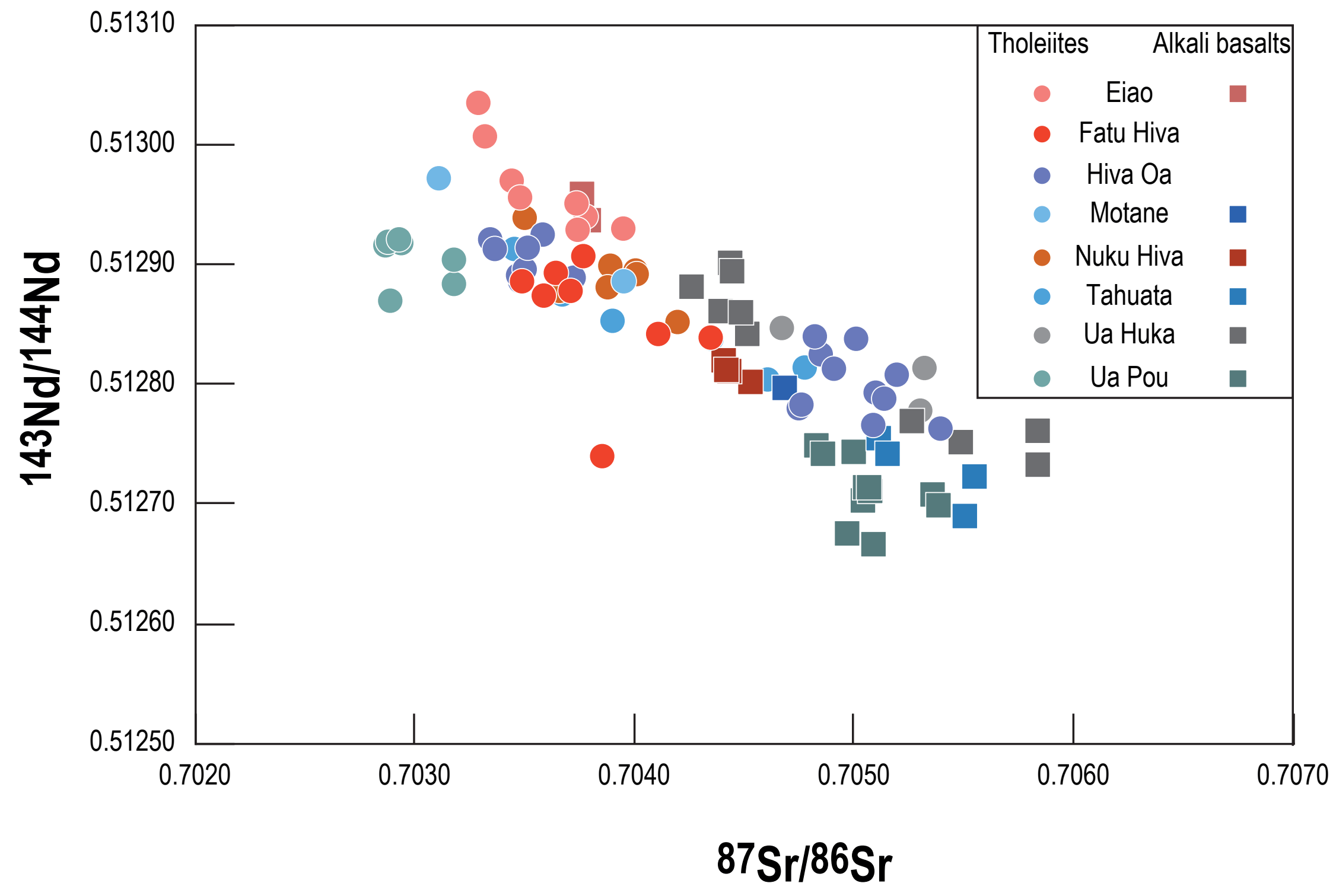

